DEPARTMENT OF THE INTERIOR

UNITED STATES GEOLOGICAL SURVEY

BIBLIOGRAPHY AND INDEX OF ARTICLES

IN THE SERIES OF U.S. GEOLOGICAL SURVEY CIRCULARS

DEVOTED TO GEOLOGIC RESEARCH AND ACCOMPLISHENTS IN ALASKA

1975-1986

Compiled by

Katherine M. Reed ${ }^{1}$ and Jane K. Marks ${ }^{2}$

OPEN-FILE REPORT

$87-420$

This report is preliminary and has not been reviewed for conformity with Geological Survey editorial standards and stratigraphic nomenclature.

1 Washington Dept. of Natural Resources, Olympia, WA 98504

2 Anchorage, AK 99508 


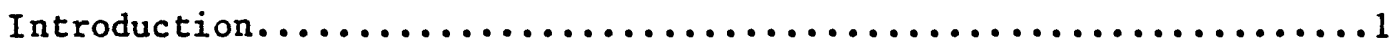

Articles arranged al phabetically by author................... Articles arranged regionally, then by subject matter

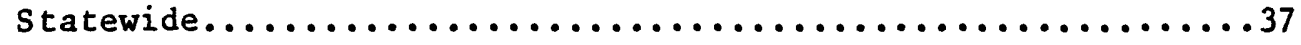

Northern Alaska.................................41

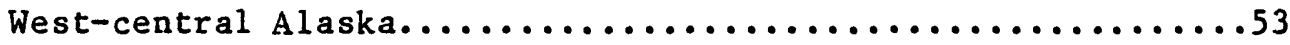

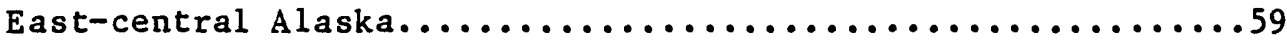

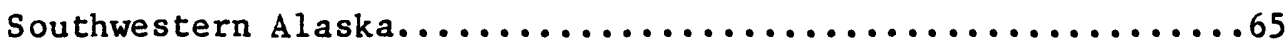

Southern Alaska....................................69

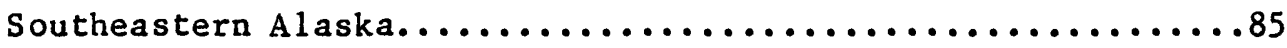

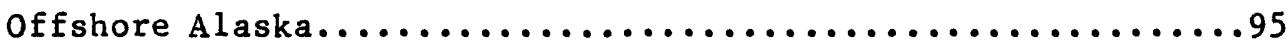

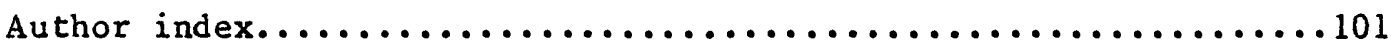

\section{PIGURE}

1. Map showing regions of Alaska used as the basis for geographic grouping of articles......................

\section{TABLES}

1. U.S. Geological Survey circulars on Alaskan research

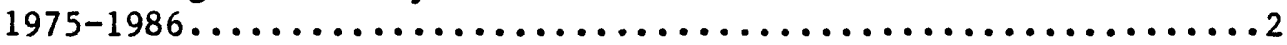

2. Regional designations, in order of presentation............

3. Subject matter categories.......................... 


\title{
BIBLIOGRAPHY AND INDEX OF ARTICLES \\ IN THE SERIES OF U.S. GEOLOGICAL SURVEY CIRCULARS \\ DEVOTED TO GEOLOGIC RESEARCH AND ACCOMPLISHAENTS IN ALASRA \\ 1975-1986
}

\author{
Katherine M. Reed and Jane R. Marks, compilers
}

\section{INTRODUCTION}

This report is a guide to the collected contents of $12 \mathrm{U} . \mathrm{S}$. Geological Survey circulars in the series titled "The United States Geological Survey in Alaska-Accomplishments during 19 " published for the years 1975-1984, and "Geologic studies in Alaska by the U.S. Geological Survey during 19 " published for the years 19851986. The change in title reflects an increasing emphasis on short and informative geologic reports, and decreasing concern with status reports on scientific or administrative programs.

The circulars whose contents are indexed in this report are listed in table 1 . The "Accomplishments" circular initially had a companion circular describing ongoing projects and programs in Alaska, and the two publications were lettered as $A$ and $B$ segments of the same issue number. Only the contents of the $B$ issues are included herein. The "programs" part of the circular series and the A and B designations were discontinued with the 1982 issue.

The first section of this report is a complete list of articles presented alphabetically by author. The articles are listed again under regional headings based on the regional designations used in the circulars (table 2), and subdivided by subjects within each regional designation (table 3 ). Figure 1, on p. 3 shows the geographic regions. The final part of this guide is a complete author index.

The subject matter headings are broad. Articles under a given heading emphasize that aspect of the geology of Alaska, but each article may contain a minor amount of related information that was not used as a sorting criterion. For example, an article about plutonic rocks in a large area may include one $\mathrm{K}-\mathrm{Ar}$ date. The article would be 1 isted under a regional heading, and under "general geology"; the radiometric information would not have been singled out as of primary importance.

The titles in the 1 ist of articles and the geographic and subject 1 ists are presented in an abbreviated format, for example:

Ager, T.A., 1982, Pollen studies of Quaternary-age lake sediments in the Tanana Valley, Alaska: 844, p. 64-67.

The complete bibliographic citation of that article includes the editors and full title of the circular within which it appears. These should be added from the 1 ist in table 1 , as in this example:

Ager, T.A., 1982, Pollen studies of Quaternary-age lake sediments in the Tanana Valley, Alaska, in Coonrad, W.L., ed., 1982, The United States Geological Survey in Alaska--Accomplishments during 1980: U.S. Geological Survey Circular 844, p. 64-67. 
TABLE 1.--U.S. Geological Survey circulars on Alaskan research, 1975-1986

Cobb, E.H., ed., 1976, The United States Geological Survey in Alaska--Accomplishments during 1975: U.S. Geological Survey Circular 733, 72 p.

Blean, K.M., ed., 1977, The United States Geological S vey in Alaska-Accomplishments during 1976: U.S. Geological Survey Circular 751-B, 112 p.

Johnson, K.M., ed., 1978, The United States Geological Survey in Alaska-Accomplishments during 1977: U.S. Geological Survey Circular 772-B, 115 p.

Johnson, K.M., and Williams, J.R., eds., 1979, The United States Geological Survey in Alaska--Accomplishments during 1978: U.S. Geological Survey Circular 804-B, $163 \mathrm{p}$.

Albert, N.R.D., and Hudson, Travis, eds., 1981, The United States Geological Survey in Alaska-Accomplishments during 1979: U.S. Geological Survey Circular 823-B, $151 \mathrm{p}$.

Coonrad, W.L., ed., 1982, The United States Geological S rvey in Alaska-Accomplishments during 1980: U.S. Geological Survey Circular 844, 178 p.

Coonrad, W.L., and Elliott, R.L., eds., 1984, The United States Geological Survey in Alaska--Accomplishments during 1981: U.S. Geological Survey Circular 868, $162 \mathrm{p}$.

Reed, K.M., and Bartsch-Winkler, Susan, eds., 1984, The United States Geological Survey in Alaska--Accomplishments during 1982: U.S. Geological Survey Circular $939,155 \mathrm{p}$.

Bartsch-Winkler, Susan, and Reed, K.M., eds., 1985, The United States Geological Survey in Alaska--Accompl ishments during 1983: U.S. Geological Survey Circular $945,107 \mathrm{p}$.

Bartsch-Winkler, Susan, ed., 1985, The United States Geological Survey in Alaska-Accomplishments during 1984: U.S. Geological Survey Circular 967, 97 p.

Bartsch-Winkler, Susan, and Reed, K.M., eds., 1986, Geologic studies in Alaska by the U.S. Geological Survey during 1985: U.S. Geological Survey Circular 978, 173 p.

Hamilton, T.D., and Galloway, J.P., eds., 1987, Geologic studies in Alaska by the

U.S. Geological Survey during 1986: U.S. Geological Survey Circular 998, 195 p.

TABLE 2.--Regional designations, in order of presentation. (Figure 1 shows the boundaries of the regions of Alaska and the quadrangles they include.)

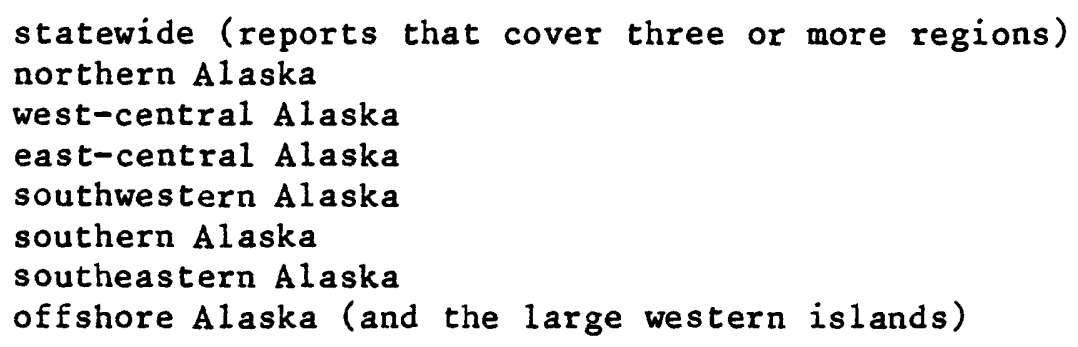




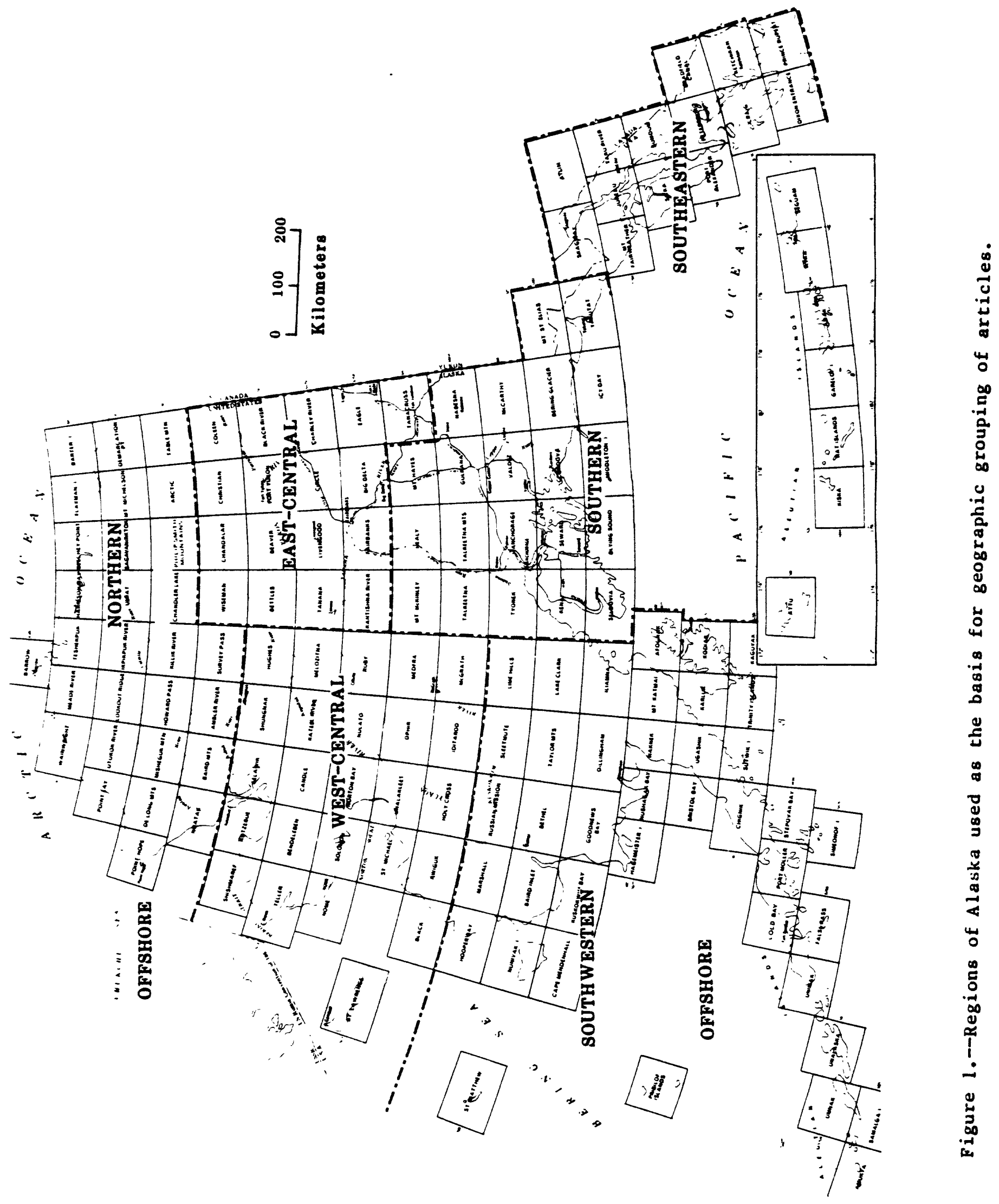


Table 3.--Subject matter categories

\begin{tabular}{|c|c|}
\hline Heading & Topics included \\
\hline $\begin{array}{l}\text { Compilations; } \\
\text { bibliographies }\end{array}$ & $\begin{array}{l}\text { Listings of reports about Alaska by year or by } \\
\text { topic }\end{array}$ \\
\hline Coal & Coal fields, coal composition, reclamation studies \\
\hline Economic geology & $\begin{array}{l}\text { Nonfuel mineral resources, uranium and rare earth } \\
\text { minerals, prospects, mines, mining, gold placers }\end{array}$ \\
\hline General geology & $\begin{array}{l}\text { Regional studies, descriptive reports, reconnaissance } \\
\text { studies, map products }\end{array}$ \\
\hline Geochemistry & Primarily geochemical surveys and rock chemistry \\
\hline Geochronology & $\begin{array}{l}\text { Radiocarbon, potassium-argon, rubidium-strontium, and } \\
\text { other isotope techniques applied to dating; some general } \\
\text { correlations }\end{array}$ \\
\hline Geophysics & $\begin{array}{l}\text { Seismic refraction and reflection, gravity, magnetics, } \\
\text { paleomagnetism }\end{array}$ \\
\hline Geothermal studies & Permafrost, hot springs, geothermal gradients \\
\hline Hydrology & $\begin{array}{l}\text { Surface water and ground water resources, streamflow, } \\
\text { limnology, hot springs, water quality, glaciology, mass- } \\
\text { balance studies, freshwater invertebrates }\end{array}$ \\
\hline Marine geology & $\begin{array}{l}\text { Offshore and nearshore geology, ice gouging, dredges, } \\
\text { continental slope and shelf areas, modern marine faunas }\end{array}$ \\
\hline Metamorphic geology & Metamorphic rocks and events \\
\hline Miscellaneous & Non-geologic subject matter \\
\hline $0 i 1$ and gas & $\begin{array}{l}\text { Oil and gas resources and investigations, NPRA data } \\
\text { releases }\end{array}$ \\
\hline Paleontology & $\begin{array}{l}\text { Fossil lists, faunal descriptions, paleontology as a } \\
\text { primary means of age determination, biostratigraphy }\end{array}$ \\
\hline Petrology; petrography & Composition and texture of rocks, diagenesis \\
\hline Quaternary geology & $\begin{array}{l}\text { Paleontology, dating, tectonics, stratigraphy, and other } \\
\text { topics known to fall within Pleistocene and Holocene age } \\
\text { limits }\end{array}$ \\
\hline Remote sensing & Landsat, side-scan sonar, and other techniques \\
\hline
\end{tabular}


Table 3.--Subject matter categories (continued)

\begin{tabular}{ll}
\hline Heading & Topics included \\
\hline Sedimentary geology & $\begin{array}{l}\text { Facies studies, stratigraphy, pal eoenvironmental } \\
\text { analyses, sedimentology }\end{array}$ \\
$\begin{array}{l}\text { Seismicity } \\
\begin{array}{l}\text { Structural geology; } \\
\text { tectonics }\end{array}\end{array}$ & $\begin{array}{l}\text { Fault systems, tectonostratigraphy, regional } \\
\text { structure, terranes }\end{array}$ \\
$\begin{array}{l}\text { Surficial geology } \\
\text { Volcanoes; volcanic rocks }\end{array}$ & Eruptions, tephras \\
\hline
\end{tabular}




\section{ARTICLES ARRANGED ALPHABETICALLY BY AUTHOR}

Anonymous, 1977, Reports on Alaska published by the U.S. Geological Survey, 1976: $751-B$, P. B 104-B 112 .

1978, Reports on Alaska published by the U.S. Geological Survey in 1977: 772-B, P. B102-B110.

Ager, T.A., 1982, Pollen studies of Quaternary-age lake sediments in the Tanana Valley, Alaska: 844 , p. 64-67. 1982, Quaternary history of vegetation in the north Alaska Range: 844, P. 109-111.

Ager, T.A., and Bradbury, Platt, 1982, Quaternary history of vegetation and climate of the Yukon Delta-Norton Sound area: 844, p. 78-80.

Ager, T.A., and Sims, J.D., 1984, Postglacial pollen and tephra records from lakes in the Cook Inlet region, southern Alaska: 868, p. 103-105.

Ahlbrandt, T.S., and Huffman, A.C., 1978, Cretaceous Nanushuk Group, North Slope, Alaska: $772-B$, P. B13-B15.

Albert, N.R.D., 1976, LANDSAT data interpretation, Nabesna and McCarthy quadrangles: 733 , p. 49-50.

Albert, N.R.D, and Steele, W.C., 1977, LANDSAT data interpretation, McCarthy, $\mathrm{T}$ anacross, and Talkeetna quadrangles: 751-B, p. B58-B61. 1979, Clay model showing deformation of the Wrangell Mountains along gravitycorrelative Landsat lineaments in the McCarthy quadrangle, Alaska: 804-B, p. B101-B102.

Albert, N.R.D., Steele, W.C., and LeCompte, J.R., 1978, Landsat color mosaic of Alaska: $772-B$, P. B1-B4. 1978, Landsat data interpretation of various AMRAP quadrangles, Alaska: 772-B, p. B4-B5.

Aleinikoff, J.N., Dusel-Bacon, Cynthia, and Foster, H.L., 1981, Geochronologic studies in the Yukon-Tanana Upland, east-central Alaska: 823-B, P. B34-B37. 1984, Uranium-lead isotopic ages of zircon from sillimanite gneiss and implications for Paleozoic metamorphism, Big Delta quadrangle, east-central Alaska: 868 , p. 45-48.

Aleinikoff, J.N., Foster, H.L., Nokleberg, W.J., and Dusel-Bacon, Cynthia, 1984, Isotopic evidence from detrital zircons for Early Proterozoic crustal material, east-central Alaska: 868, p. 43-45.

Aleinikoff, J.N., and Nokleberg, W.J., 1984, Early Proterozoic metavolcanic rocks in the Jarvis Creek Glacier tectonostratigraphic terrane, Mount Hayes C-6 quadrangle, eastern Alaska Range, Alaska: 939, p. 40-44. 1984, Uranium-lead geochronology of a metarhyodacite from the Pingston terrane, Mount Hayes C-6 quadrangle, eastern Alaska Range: 868, p. 73-75. 1985, Age of Devonian intrusion and metamorphism of a granodiorite in the Lake George terrane, northeastern Mount Hayes quadrangle: 945, p. 62-65. 1985, Age of Devonian igneous-arc terranes in the northern Mount Hayes quadrangle, eastern Alaska Range: 967 , p. 44-49.

Aleinikoff, J.N., Nokleberg, W.J., and Herzon, P.L., 1982, Age of intrusion and metamorphism of the East Susitna batholith, Mount Hayes B-6 quadrangle, eastern Alaska Range, Alaska: 844, p. 100-102.

Allaway, W.H., Jr., and Miller, J.W., 1984, Newly recognized sedimentary environments in the Shelikof Formation: 868, p. 34-37.

Anderson, G.S., 1976, Water-resources reconnaissance of St. George Island, Pribilof Islands: 733 , p. 43. 1976, Lake level fluctuations, North Kenai area: 733, p. 54.

Angeloni, L.M., and Miller, M.L., 1985, Greenschist facies metamorphic rocks of north-central Iditarod quadrangle: 967 , p. 19-21. 
Antweiler, J.C., Tripp, R.B., Cathrall, J.B., and Mosier, E.L., 1985, Studies of gold in the Chandalar and Koyukuk districts, Wiseman and Bettles quadrangles-A progress report: 945 , p. 28-29.

Armstrong, A.K., 1982, Petrography and cathode luminescence of carbonate rocks at Bornite, Alaska: 844 , p. 38-40.

Armstrong, A.K., Harris, A.G., Reed, B.L., and Carter, Claire, 1977, Paleozoic sedimentary rocks in the northwest part of the Talkeetna quadrangle, Alaska Range, Alaska: 751-B, P. B61-B64.

Armstrong, A.K., and MacKevett, E.M., Jr., 1976, Relations between Triassic carbonate sabkhas and Kennecott-type copper deposits, Wrangell Mountains: 733, p. 50-51. 1977, Carbonate sedimentation, sabkha facies, diagenesis, and stratigraphy, lower part of the Chitistone Limestone--The Triassic host rock for Kennecotttype copper deposits: 751-B, p. B56.

Armstrong, A.K., and Mamet, B.L., 1977, Carboniferous microfacies, microfossils, and corals, Lisburne Group, arctic Alaska: 751-B, p. B18. 1977, Mississippian microfacies of the Lisburne Group, Endicott Mountains, arctic Alaska: 751-B, p. B18-B19.

Balding, G.0., 1976, Aquifer investigations in Mendenhall Valley near Juneau: 733, p. 60 .

1979, Surface-water data from molybdenum resource area, Keta River basin: 804-B, P. B131-B 132 .

Barnes, D.F., 1976, New gravity map of Alaska: 733, p. 2-5. 1981, Gravity measurements useful in exploration and evaluation of the Nimiuktuk barite deposit: 823-B, P. B15-B17. 1984, Digital elevation models improve processing of Alaskan gravity data: 868, p. 5-7.

1984, No measurable gravity change at Glacier Bay regional uplift area: 939, p. $88-90$.

1985, Gravity lows may indicate Pleistocene deposits beneath glacial Lake Noatak: 967, p. $1-5$. 1986, Gravity data indicate large mass and depth of the gabbro body at haines: 978 , p. 88-92.

Barnes, D.F., and Csejtey, Bela, Jr., 1985, Strong magnetic and gravity contrasts across the Talkeetna, Totschunda, and Eureka Creek faults versus the lesser geophysical expression of the Denali fault and its strands-A geological puzzle for TACT program: 945, p. 65-68.

Barnes, D.F., and Morin, R.L., 1984, Gravity measurements show large size of Red Dog zinc-lead-barite prospect in northwestern Alaska: 939, p. 1-5.

Barnes, D.F., and Plouff, Donald, 1984, Computer-generated latitude and longitude templates for rapid determination of geographic positions in Alaska: 868, p. $10-11$.

Barnes, D.F., and Watts, R.D., 1977, Geophysical surveys in Glacier Bay National Monument: 751-B, p. B93-B94.

Barnes, Ivan, Plafker, George, White, L.D., and Armstrong, A.K., 1982, Potential natural gas in the Gulf of Alaska indicated by calcite depleted in carbon-13: 844, p. 143-146.

Barnes, P.W., Graves, Scot, and Reimnitz, Erk, 1987, Beaufort Sea coastal currents--A divergence near Barter Island, Alaska?: 998, p. 139-142.

Barnes, P.W., and Reimnitz, Erk, 1976, Sediment-ice interaction in the Beaufort Sea: 733 , p. 17-21.

Barton, C.C., and Light, T.D., 1987, Structural fabric analysis of the Perseverance slate and gold-bearing quartz veins in the south ore body of the Alaska-Juneau lode system, southeastern Alaska: 998, p. 110-112.

Bartsch-Winkler, Susan, 1986, Channel migration in Turnagain Arm: 978, p. 29-33. 
Bartsch-Winkler, Susan, Emanuel, R.P., and Winkler, G.R., 1985, Reconnaissance hydrology and suspended sediment analysis, Turnagain Arm, upper Cook Inlet: 967 , p. 49-52.

Bartsch-Winkler, Susan, and Garrow, H.C., 1982, Depositional system approaching maturity at Portage Flats: 844 , p. 115-117.

Bartsch-Winkler, Susan, and Huffman, A.C., 1981, Compositional variation in sandstones of the Nanushuk Group, Arctic North Slope: 823-B, P. B6-B8.

Bartsch-Winkler, Susan, and Schmoll, H.R., 1984, Convoluted beds in late Holocene intertidal sediment at the mouth of Knik Arm, upper Cook Inlet, Alaska: 868, p. $105-108$.

1987, Earthquake-caused sedimentary couplets in the Upper Cook Inlet region: 998, p. 92-95.

Behrendt, E.C., 1984, The U.S. Geological Survey Public Inquiries office in Anchorage: 868, p. 11-12.

Beikman, H.M., 1977, Preliminary geologic map of Alaska: 751-B, P. B1.

Berg, H.C., 1979, Significance of geotectonics in the metallogenesis and resource appraisal of southeastern Alaska--A progress report: 804-B, p. B116. 1981, Upper Triassic volcanogenic massive-sulfide metallogenic province identified in southeastern Alaska: 823-B, P. B104-B108.

Berg, H.C., Elliott, R.L., and Koch, R.D., 1976, Progress report on geology and mineral resources of the Ketchikan quadrangle: 733, p. 62-65

Berg, H.C., Elliott, R.L., Smith, J.G., and Koch, R.D., 1978, New geological map of Ketchikan and Prince Rupert quadrangles, southeastern Alaska: 772-B, p. B82-B83.

Berg, H.C., Smith, J.G., Elliott, R.L., and Koch, R.D., 1977, Structural elements of Insular Belt and Coast Range plutonic complex near Ketchikan, Alaska-A progress report: $751-B, \mathrm{p} . \mathrm{B} 76-\mathrm{B} 78$.

Bird, K.J., 1976, Petroleum potential of the Lisburne Group, eastern Arctic Slope: 733 , p. 26.

1977, Late Paleozoic carbonates from the south-central Brooks Range: 751-B, P. B19-B20.

Bird, K.J., Connor, C.L., Tailleur, I.L., Silberman, M.L., and Christie, J.L., 1978, Granite on the Barrow arch, northeast NPRA: 772-B, P. B24-B25.

Blackford, Michael, 1977, Seismicity patterns in the Cook Inlet, Prince William Sound region, Alaska: 751-B, P. B94-B96.

Blanchard, D.C., and Tailleur, I.L., 1982, Preliminary geothermal isograd map, NPRA: 844, P. 46-48.

Blodgett, R.B., Clough, J.G., Dutro, J.T., Jr., Ormiston, A.R., Palmer, A.R., and Taylor, M.E., 1986, Age revisions for the Nanook Limestone and Katakturuk Dolomite, northeastern Brooks Range: 978, p. 5-10.

Blodgett, R.B., Wheeler, K.L., Rohr, D.M., Harris, A.G., and Weber, F.R., 1987, A Late Ordovician age reappraisal for the Upper Fossil Creek Volcanics, and possible significance for glacio-eustasy: 998, p. 54-58.

Blueford, J.R., 1986, New radiolarian data from the Orca Group, Prince William Sound: 978, p. 33-34.

Boucher, Gary, 1976, Study of the gravity field of the Beaufort shelf, north coast of Alaska: 733 , p. 21-22.

Box, S.E., 1985, Terrane analysis of the northern Bristol Bay region, southwestern Alaska: 967, p. 32-37.

1985, Geologic setting of high-pressure metamorphic rocks, Cape Newenham area, southwestern Alaska: 967 , p. 37-42.

Box, S.E., and Murphy, J.M., 1987, Late Mesozoic structural and stratigraphic framework, eastern Bethel quadrangle, southwestern Alaska: 998, p. 78-82. 
Box, S.E., Patton, W.W., Jr., and Carlson, Christine, 1985, Early Cretaceous evolution of the northeastern Yukon-Koyukuk basin, west-central Alaska: 967 , P. 21-24.

Brew, D.A., 1987, Cenozoic magmatism in southeastern Alaska abstract : 998, p. 137. Brew, D.A., Berg, H.C., Morrell, R.P., Sonnevil, R.A., Hunt, S.J., and Huie, Carl, 1979, The Tertiary Kuiu-Etolin volcanic-plutonic belt, southeastern Alaska: 804-B, P. B129-B 130 .

Brew, D.A., Carlson, Christine, and Nutt, C.J., 1976, Apparent pre-middle Tertiary right-1ateral offset on Excursion Inlet fault, Glacier Bay National Monument: 733 , p. 59.

Brew, D.A., and Ford, A.B., 1977, Coast Range megalineament and Clarence strait lineament on west edge of Coast Range batholithic complex, southeastern

Alaska: 751-B, p. B79.

1981, The Coast plutonic complex sill, southeastern Alaska: 823-B, P. B96-B99. 1984, The northern Coast plutonic-metamorphic complex, southeastern Alaska and northwestern British Columbia: 868, p. 120-124.

1984, Tectonostratigraphic terranes in the Coast plutonic-metamorphic complex, southeastern Alaska: 939, p. 90-93.

1985, Southeastern Alaska coincident zone: 967, p. 82-86.

1987, The Meade Glacier Fault--An important tectonic boundary in the Northern Cordillera, southeastern Alaska: 998, p. 113-115.

Brew, D.A., Ford, A.B., and Garwin, S.L., 1985, Fossiliferous Middle and (or) Upper Triassic rocks within the Coast plutonic-metamorphic complex southeast of Skagway: 967 , p. 86-89.

Brew, D.A., Ford, A.B., Grybeck, Donald, Johnson, B.R., and Nutt, C.J., 1976, Key foliated quartz diorite sill along southwest side of Coast Range complex, northern southeastern Alaska: 733 , p. 60.

Brew, D.A., Grybeck, Donald, and Johnson, B.R., 1979, Sumary of mineral resources, Glacier Bay National Monument Wilderness Study Area, southeastern Alaska: 804-B, p. B112-B114.

Brew, D.A., Grybeck, Donald, Johnson, B.R., and Nutt, C.J., 1976, Glacier Bay National Monument mineral-resource studies recoumended: 733, p. 58-59.

Brew, D.A., Himelberg, G.R., Ford, A.B., and Jachens, R.C., 1987, Ultramafic and mafic sills in the vicinity of the Treadwell gold deposits, Douglas Island, southeastern Alaska: 998 , p. 119-123.

Brew, D.A., Johnson, B.R., Ford, A.B., and Morre11, R.P., 1978, Intrusive rocks in the Fairweather Range, Glacier Bay National Monument: 772-B, p. B88-B90.

Brew, D.A., Johnson, B.R., Nutt, C.J., Grybeck, Donald, and Ford, A.B., 1977, Newly discovered granitic and gabbroic bodies in the Fairweather Range, Glacier Bay National Monument, Alaska: 751-B, P. B90-B91.

Brew, D.A., Karl, S.M., and Tobey, E.F., 1985, Re-Interpretation of the age of the Kuiu-Etolin belt volcanic rocks, Kupreanof Island, southeastern Alaska: 945 , p. 86-88.

Brew, D.A., Loney, R.A., Kistler, R.W., Czamanske, G.K., Gromme, C.S., and Tatsumoto, Mitsunobu, 1977, Probable Precambrian or lower Paleozoic rocks in the

Fairweather Range, Glacier Bay National Monument, Alaska: 751-B, P. B91-B93.

Brew, D.A., and Morrel1, R.P., 1978, Tarr Inlet suture zone, Glacier Bay National Monument, Alaska: 772-B, p. B90-B91.

1979, Intrusive rock belts of southeastern Alaska: 804-B, P. B116-B121. 1979, The Wrangell terrane ("Wrangellia") in southeastern Alaska--The Tarr Inlet suture zone with its northern and southern extensions: 804-B, P. B121-B123. 1979, Correlation of the Sitka Graywacke, unnamed rocks in the Fairweather Range, and Valdez Group, southeastern and south-central Alaska: 804-B, P. B123-B125. 
Brew, D.A., Sonnevil, R.A., Hunt, S.J., and Ford, A.B., 1981, Newly recognized alkali granite stock, southwestern Kupreanof Island, Alaska: 823-B, p. B108-B109.

Brigham, J.K., 1984, Marine stratigraphy and amino acid geochronology of the Gubik Formation, western Arctic Coastal Plain, Alaska: 939, p. 5-9.

Brosge, W.P., and Reiser, H.N., 1977, Lead-zinc mineralization at Bear Mountain, southeastern Brooks Range: 751-B, P. B8-B10.

Brosge, W.P., Reiser, H.N., and Dutro, J.T., Jr., 1981, Significance of Middle Devonian clastic rocks in the eastern Brooks Range, Alaska: 823-B, p. B24-B25.

Brouwers, E.M., 1982, Preliminary report on ostracode assemblages from the northeast Gulf of Alaska continental shelf: 844, p. 151-153. 1984, Paleoenvironmental analysis of the ostracodes in Quaternary sediment from cores taken near Icy Bay, Gulf of Alaska: 868, p. 136-139.

Brouwers, E.M., Marincovich, Louie, Jr., and Hopkins, D.M., 1984, Paleoenvironmental record of $P$ leistocene transgressive events preserved at Skull Cliff, northern Alaska: 939, p. 9-12.

Brouwers, E.M., and McDougall, Kristin, 1984, Preliminary analysis of microfauna from selected bottom grab samples, southern Bering Sea: 868, p. 140-141.

Bruns, T.R., Fisher, M.A., Carlson, P.R., Rearic, D.M., and Parson, L.M., 1987, GLORIA images obtained in the TACT corridor of the Aleutian convergent margin, northern Gulf of Alaska abstract : 998, p. 170.

Bruns, T.R., and Plafker, George, 1976, Structural style of part of the Outer Continental Shelf in the Gulf of Alaska Tertiary Province: 733, p. 13-14.

Bruns, T.R., Vallier, T.L., Pickthorn, L.B., and von Huene, Roland, 1987, Volcanicarc dacite and early Miocene basalt dredged from the Shumagin margin, Alaska: 998 , p. 143-146.

Bruns, T.R., and von Heune, Roland, 1977, Sedimentary basins on the Shumagin shelf, western Gulf of Alaska: 751-B, p. B97.

Burack, A.C., Laird, Jo, Foster, H.L., and Cushing, G.W., 1984, Metamorphic petrology of the Table Mountain area, Circle quadrangle, Alaska: 868, p. 54-57.

Burrel1, P.D., 1984, Cretaceous plutonic rocks, Mitkof and Kupreanof Islands, Petersburg quadrangle, southeastern Alaska: 868, p. 124-126. 1984, Late Cretaceous plutonic rocks, Petersburg quadrangle, southeast Alaska: 939, p. 93-96.

Burroughs, R.L., Emmett, W.W., and Parks, Bruce, 1982, Sediment transport in the Tanana River in the vicinity of Fairbanks, Alaska: 844, p. 67-69.

Cady, J.W., 1986, Geophysics of the Yukon-Koyukuk province: 978, p. 21-25.

Callahan, J.E., 1976, Northern Alaska coal investigations, western Naval Petroleum Reserve No. 4: 733 , p. 30 .

Campbel1, D.L., and Barnes, D.F., 1985, Gravity and magnetic model of a part of the 1984 TACT line, Chugach Mountains and southern Copper River basin: 967, p. 52-55.

Campbel1, D.L., and Nokleberg, W.J., 1984, Magnetic profile across accreted terranes, Mount Hayes quadrangle, eastern Alaska Range, Alaska: 939, p. 44-47. 1985, Magnetic profile across Denali fault, Mount Hayes quadrangle, eastern Alaska Range: 945 , p. 68-72. 1986, Magnetic model of a profile across northern Copper River basin, northeastern Gulkana quadrangle: 978 , p. 35-38.

Carlson, P.R., Karl, H.A., Johnson, K.A., and Fischer, J.M., 1982, Submarine canyons flanking Navarin Basin, Bering Sea: 844, p. 139-141.

Carlson, P.R., and Molnia, B.F., 1976, Submarine mass movement of Holocene sediments seaward of the Copper River: 733, p. 55-56.

Carlson, P.R., Molnia, B.F., Bruns, T.R., and Whitney, J.W., 1977, Shelf-edge scarps in the northern Gulf of Alaska: 751-B, P. B96-B97. 
Carlson, P.R., Plafker, George, Bruns, T.R., and Levy, W.P., 1979, Seaward extension of the Fairweather fault: 804-B, P. B135-B139.

Carlson, P.R., Wheeler, M.C., Molnia, B.F., and Atwood, T.J., 1979, Neoglacial sedimentation in Glacier Bay, Alaska: 804-B, P. B114-B116.

Carter, L.D., and Galloway, J.P., 1979, Arctic Coastal Plain pingos in National Petroleum Reserve in Alaska: 804-B, P. B33-B34. 1979, Southward-progressing stabilization of Holocene eolian sand on the western Arctic Coastal Plain: 804-B, p. B37-B39. 1982, Terraces of the Colville Delta region, Alaska: 844, p. 49-51. 1984, Lacustrine and eolian deposits of Wisconsin age at Riverside Bluff in the upper Tanana River valley, Alaska: 868, p. 66-68.

Carter, L.D., Marincovich, Louie, Jr., Brouwers, E.M., and Forester, R.M., 1979, Paleogeography of a Pleistocene coastline, Alaskan Arctic Coastal Plain: 804-B, p. B39-B41.

Carter, L.D., Repenning, C.A., Marincovich, L.N., Hazel, J.E., Hopkins, D.M., McDougal1, Kristin, and Naeser, C.W., 1977, Gubik and pre-Gubik Cenozoic deposits along the Colville River near Ocean Point, North Slope, Alaska: 751-B, P. B12-B 14 .

Carter, L.D., and Robinson, S.W., 1981, Minimum age of beach deposits north of Teshekpuk Lake, Alaskan Arctic Coastal Plain: 823-B, P. B8-B9.

Carter, R.D., 1976, North Slope petroleum program: 733, p. 23-24. 1978, Release of NPRA (NPR-4) data: 772-B, P. B26-B27. 1981, National Petroleum Reserve in Alaska-Data release: 823-B, p. B3-B4. 1982, NPRA data release, 1980: 844, p. 48-49.

Carter, R.D., and Lantz, R.J., 1978, Development and operation of gas fields in the South Barrow area: 772-B, P. B29-B30. 1979, Development and operation of gas fields in the Barrow area: 804-B, P. B52-B53.

Carter, R.D., and Madrid, R.J., 1979, Availability of NPRA data: 804-B, P. B53.

Carter, R.D., Mull, C.G., and Bird, K.J., 1977, Any Prudhoe Bays in Naval Petroleum Reserve No. 4?: 751-B, P. B14-B15.

Case, J.E., Cox, D.P., Detra, D.E., Detterman, R.L., and Wilson, F.H., 1982, Aeromagnetic survey of Chignik and Sutwik Island quadrangles: 844, p. 88-89.

Cathral1, J.B., 1982, Potential mineralized target areas in the Brooks Range schist belt are characterized by anomalous stream-sediment geochemistry, magnetic and lithologic signature: 844 , p. 40-41. 1982, Evidence from stream-sediment geochemical and biogeochemical data, mineral occurrences, and Landsat images for potential mineralized targets in the Brooks Range, Alaska: 844, P. 41.

Chapman, R.M., 1976, Progress report on new geologic mapping in the Ruby quadrangle: 733 , p. 41-42. 1977, Geochemical anomalies in bedrock, west half of Kantishna River quadrangle: $751-B$, P. B35-B 36 .

Chapman, R.M., Churkin, Michael, Jr., Carter, Claire, and Trexler, J.H., Jr., 1981, Ordovician graptolites and early Paleozoic radiolarians in the Lake Minchumina area date a regional shale and chert belt: 823-B, P. B32-B34.

Chapman, R.M., and Patton, W.W., Jr., 1978, Preliminary summary of the geology of the northwest part of the Ruby quadrangle: 772-B, P. B39-B41. 1978, Landslides near Melozitna River canyon: 772-B, P. B41-B42, B43. 1979, Two upper Paleozoic sedimentary rock units identified in southwestern part of the Ruby quadrangle: 804-B, P. B59-B61.

Chapman, R.M., Patton, W.W., Jr., and Moll, E.J., 1982, Preliminary summary of the geology in eastern part of Ophir quadrangle: 844, p. 70-72. 
Chapman, R.M., Trexler, J.H., Jr., Churkin, Michael, Jr., and Weber, F.R., 1985, New concepts of the Mesozoic flysch belt in east-central Alaska: 945, p. 29-32.

Chapman, R.M., and Yeend, Warren, 1981, Geologic reconnaissance of the east half of Kantishna River quadrangle and adjacent areas: 823-B, P. B30-B32.

Childers, J.M., 1976, Streamflow, channel erosion, and icings along TAPS route: 733 , p. 8 .

1976, Arctic water resources and environmental studies: 733, p. 9.

Childers, J.M., and Kernodle, D.R., 1979, Water resources of the Noatak River basin: 804-B, P. B53-B54. 1982, Hydrologic reconnaissance of the Kobuk River basin: 844, p. 80-81.

Childers, J.M., Kernodle, D.R., and Loeffler, R., 1978, Stream flow and channel erosion investigations along the TAPS route: $772-B$, P. B6-B7. 1978, Hydrology of arctic Alaska: 772-B, P. B33-B34.

Childs, J.R., Scholl, D.W., and Vallier, Tracy, 1981, Onshore and offshore studies, Amlia Island area, Aleutian Ridge: 823-B, P. B134-B138.

Church, S.E., Briskey, J.A., Delevaux, M.H., and LeHuray, A.P., 1985, Preliminary results of $\mathrm{Pb}$-isotope analyses of deposits from the Seward Peninsula: 967, p. 24-27.

Church, S.E., Gray, J.E., and Delevaux, M.H., 1986, Use of Pb-isotopic signatures for geochemical exploration in the Healy quadrangle, eastern Alaska Range: 978, p. 38-41.

Churkin, Michael, Jr., Carter, Claire, and Johnson, B.R., 1977, A new Ordovician time scale based on accumulation rates of graptolitic shale: 751-B, B4-B5.

Churkin, Michael, Jr., and Eberlein, G.D., 1977, Correlation of the rocks of southeastern Alaska with other parts of the Cordillera: 751-B, P. B69-B72.

Churkin, Michael, Jr., Huie, Car1, Mayfield, C.F., and Nokleberg, W.J., 1978, Geologic investigations of metallic mineral resources of southern NPRA: 772-B, p. B15-B17.

Churkin, Michael, Jr., Nokleberg, W.J., and Huie, Carl, 1979, Tectonic model for the western Brooks Range, Alaska: 804-B, P. B22-B25.

Churkin, Michael, Jr., Reed, B.L., Carter, Claire, and Winkler, G.R., 1977, Lower Paleozoic graptolitic section in the Terra Cotta Mountains, southern Alaska Range: 751-B, p. B37-B38.

Churkin, Michael, Jr., Trexler, J.H., Jr., and Carter, Claire, 1982, Graptolites discovered in the Woodchopper Volcanics: 844, p. 53-56.

Cobb, E.H., 1976, Mineral resources of Alaska: 733, p. 2. 1977, Mineral resources of Alaska: 751-B, p. B1-B4.

1978, Mineral resources of Alaska: 772-B, p. B1.

1979, Mineral resources of Alaska: 804-B, p. B1.

comp., 1979, Reports on Alaska published by the U.S. Geological Survey in

1978: 804-B, P. B147-B158.

comp., 1981, Reports on Alaska published by the U.S. Geological Survey in 1979: 823-B, P. B138-B145.

comp., 1982, Reports on Alaska published by the U.S. Geological Survey in 1980: 844, p. 154-165.

comp., 1984, Reports on Alaska published by the U.S. Geological Survey in 1981: 868, p. 141-153.

Coney, P.J., Silberling, N.J., Jones, D.L., and Richter, D.H., 1981, Structural relations along the leading edge of the Wrangellia terrane in the Clearwater Mountains, Alaska: 823-B, p. B56-B58.

Connor, C.L., 1984, A middle Wisconsin pollen record from the Copper River basin, Alaska: 868 , p. 102-103. 
Collett, T.S., Kvenvolden, K.A., Magoon, L.B., and Bird, K.J., 1987, Geochemical and geologic controls on the inferred occurrence of natural gas hydrate in the Kuparuk 2D-15 well, North Slope, Alaska: 998, p. 24-26.

Coonrad, W.I., and Hoare, J.M., The Togiak tuya: 733, p. 44-45

Cooper, A.K., 1977, Marine geophysical investigations in the Bering Sea basin: $751-B$, P. B $98-B 100$.

1978, Heat flow and organic gas measurements from the Aleutian Basin, Bering Sea: 772-B, P. B92-B94.

Cooper, A.K., and Marlow, M.S., 1979, Geologic and geophysical cruise across the outer Bering continental margin: 804-B, P. B132-B134. 1984, Geophysical and geological studies of the Bering Sea Shelf: 939, p. 123-127.

Cowing, D.J., and Emanuel, Richard, 1982, Water resources of the Anchorage area: 844 , p. 117 .

Csejtey, Bela, Jr., 1979, Regional significance of tectonics of the Talkeetna Mountains, south-central Alaska: 804-B, P. B90-B92.

Csejtey, Bela, Jr., Cox, D.P., Evarts, R.C., Stricker, G.D., and Mullen, M.W., 1982, The Denali fault system of Alaska--The case for minor rather than major Cenozoic lateral displacement: 844, p. 102-106.

Csejtey, Bela, Jr., and Evarts, R.C., 1979, Serpentinite bodies in the Willow Creek district, southwestern Talkeetna Mountains, Alaska: 804-B, p. B92-B93.

Csejtey, Bela, Jr., and Nelson, W.H., 1979, Trondhjemite in the Talkeetna Mountains, south-central Alaska: 804-B, P. B93-B96.

Csejtey, Bela, Jr., Nelson, W.H., Jones, D.L., and Silberling, N.J., 1978, Tectonic significance of newly discovered lower Paleozoic strata in the upper Chulitna Valley, south-central Alaska: 772-B, P. B69-B70.

Csejtey, Bela, Jr., and St. Aubin, Dennis, 1981, Evidence for northwestward thrusting of the Talkeetna superterrane and its regional significance: 823-B, $P$. B49-B51.

Csejtey, Bela, Jr., Yeend, W.E., and Goerz, D.J., III, 1984, Occurrence of the Cantwell(?) Formation south of the Denali fault system in the Healy quadrangle, southern Alaska: 868 , p. 77-79.

Curtin, G.C., Crim, W.D., King, H.D., Cooley, E.F., Forn, C.L., Hoffman, J.D., O'Leary, R.M., and Tripp, R.B., 1979, Reconnaissance geochemical studies in Alaska: 804-B, p. B4-B5.

Curtin, G.C., Day, G.W., Forn, C.L., Hessin, T.D., Hoffman, J.D., Marsh, S.P., O'Leary, R.M., and Tripp, R.B., 1976, Exploration geochemistry in Alaska: 733, p. 5-7.

Curtin, G.C., Hessin, T.D., O'Leary, R.M., Cooley, E.F., Day, G.W., and Tripp, R.B., 1978, Geochemical exploration studies in Alaska: 772-B, P. B5-B6.

Curtin, G.C., Tripp, R.B., O'Leary, R.M., and Huston, D.L., 1984, Geochemically anomalous areas north of the Denali fault in the Mount Hayes quadrangle, southern Alaska: 868 , p. 92-93.

Curtis, S.M., Rossiter, Richard, Ellersieck, I.F., Mayfield, C.F., and Tailleur, I.L., 1979, Gamma-ray values in the Misheguk Mountain region and in parts of Barrow, Teshekpuk, and Harrison Bay quadrangles: 804-B, P. B14.

Cushing, G.W., and Foster, H.L., 1984, Structural observations in the Circle quadrangle, Yukon-T anana Upland, Alaska: 868, p. 64-65.

Cushing, G.W., Foster, H.L., Laird, Jo, and Burack, A.C., 1982, Description and preliminary interpretation of folds and faults in a small area in the Circle $B-4$ and $B-5$ quadrangles, Alaska: 844, P. 56-58.

Dearborn, L.L., and Balding, G.0., 1979, Ground-water data from molybdenum resource area, Keta River basin: 804-B, P. B131.

Decker, John, and Johnson, B.R., 1981, The nature and position of the Border Ranges fault on Chichagof Island: 823-B, P. B102-B 104. 
Decker, J.E., and Hoare, J.M., 1982, Sedimentology of the Cretaceous Kuskokwim Group, southwest Alaska: 844, p. 81-83.

Decker, John, Nilsen, T.H., and Kar1, Susan, 1979, Turbidite facies of the Sitka Graywacke, southeastern Alaska: 804-B, P. B125-B129.

Decker, J.E., and Plafker, George, 1982, Correlation of rocks in the Tarr Inlet suture zone with the Kelp Bay Group: 844, p. 119-123.

Detra, D.E., Detterman, R.L., Cox, D.P., Wilson, F.H., and Theodore, T.G., 1982, Reconnaissance geochemical studies in the Bristol Bay, Ugashik and Karluk quadrangles, Alaska: 844, p. 87-88.

Detterman, R.L., 1976, Biostratigraphy of the Permian and Lower Triassic rocks in the Philip Smith Mountains quadrangle: 733, p. 32-33. 1978, Interpretation of depositional environments in the Chignik Formation, Alaska Peninsula: 772-B, P. B62-B63.

Detterman, R.L., Case, J.E., and Wilson, F.H., 1979, Paleozoic rocks on the Alaska Peninsula: 804-B, P. B85-B86.

Detterman, R.L., and Dutro, J.T., Jr., 1977, Depositional environment and fauna for a section of the Sadlerochit Group, northeastern Alaska: 751-B, P. B10-B12.

Detterman, R.L., and Miller, J.W., 1985, Kaguyak Formation--An Upper Cretaceous flysch deposit: 945, p. 49-51.

1986, A widespread catastrophic event in the Naknek Formation, Alaska Peninsula: 978 , p. 27-29.

Detterman, R.L., and Spicer, R.A., 1981, New stratigraphic assignment for rocks along Igilatvik (Sabbath) Creek, William 0. Douglas Arctic Wildlife Range, Alaska: 823-B, P. B11-B12.

Dickinson, K.A., 1979, Uraninite in sideritic nodules from Tertiary continental sedimentary rocks in the Healy Creek basin area, central Alaska: 804-B, p. B98-B99.

Dillon, J.T., Patton, W.W., Jr., Mukasa, S.B., Tilton, G.R., Blum, Joel, and Moll, E.J., 1985, New radiometric evidence for the age and thermal history of the metamorphic rocks of the Ruby and Nixon Fork terranes, west-central Alaska: 945 , p. 13-18.

Dobrovolny, Ernest, and Schmol1, H.R., 1976, Engineering geology of the Greater Anchorage Area Borough: 733, p. 52 .

Douglass, S.L., and Brew, D.A., 1985, Polymetamorphism in the eastern Petersburg quadrangle, southeastern Alaska: 967 , p. 89-92.

Dover, J.H., and Miyaoka, R.T., 1985, Major rock packages of the Ray Mountains, Tanana and Bettles quadrangles: $945, \mathrm{p} .32-36$. 1985, Metamorphic rocks of the Ray Mountains--Preliminary structural analysis and regional tectonic implications: 945 , p. 36-38.

Doyle, P.F., 1977, Streamflow and channel erosion along the TAPS route: 751-B, P. B7.

Dumoulin, J.A., and Miller, M.L., 1984, The Jeanie Point complex revisited: 868, p. $75-77$.

Dumoulin, J.A., and Till, A.B., 1985, Seacliff exposures of metamorphosed carbonate and schist, northern Seward Peninsula: 945 , p. 18-22.

Dusel-Bacon, Cynthia, 1984, Trace-element evidence for the tectonic affinities of some amphibolites from the Yukon-Tanana Upland, east-central Alaska: 868, p. 50-54.

Dusel-Bacon, Cynthia, and Bacon, C.R., 1984, Concordant bands of augen gneiss within metasedimentary rocks in the Big Delta C-2 quadrangle, east-central Alaska, 868, p. 48-50.

Dusel-Bacon, Cynthia, Stern, T.W., Foster, H.L., and Bentz, J.L., 1979, Preliminary results of an augen gneiss study, Big Delta quadrangle: 804-B, P. B57-B59. 
Dutro, J.T., Jr., 1978, Potential strata-bound lead-zinc mineralization, Philip Smith Mountains quadrangle, Alaska: 772-B, P. B9-B11.

Dutro, J.T., Jr., Armstrong, A.K., Douglass, R.C., and Mamet, B.L., 1981 , Carboniferous biostratigraphy, southeastern Alaska: 823-B, p. B94-B96.

Dutro, J.T., Jr., Brosge, W.P., and Reiser, H.N., 1977, Upper Devonian depositional history, central Brooks Range, Alaska: 751-B, p. B16-B18.

Dutro, J.T., Jr., Palmer, A.R., Repetski, J.E., Jr., and Brosge, W.P., 1984, The Doonerak anticlinorium revisited: 868 , p. 17-19.

Dutro, J.T., Jr., and Patton, W.W., Jr., 1981, Lower Paleozoic platform carbonate sequence in the Medfra quadrangle, west-central Alaska: 823-B, P. B42-B44.

Duttweiler, K.A., 1986, Sulfide occurrences in the Itkillik River region, southeast Chandler Lake quadrangle, Brooks Range: 978, p. 10-13. 1987, Use of factor analysis in locating base metal mineralization in the Killik River quadrangle, Alaska: 998, p. 27-30.

Eberlein, G.D., and Churkin, Michael, Jr., 1976, Progress report on geologic investigations in the Craig quadrangle: 733, p. 61-62.

Egbert, R.M., 1981, Petrography and provenance of Upper Cretaceous sandstone from Saddle Mountain in the Iniskin-Tuxedni area, lower Cook Inlet, Alaska: 823-B, P. B88-B90.

Egbert, R.M., and Magoon, L.B., 1981, Petrography, provenance, and tectonic significance of Middle and Upper Jurassic sandstone from Tuxedni Bay, Cook Inlet, Alaska: 823-B, p. B86-B88.

Eittreim, Stephen, Grantz, Arthur, and Whitney, 0.T., 1977, Tectonic imprints on sedimentary deposits in Hope basin: 751-B, p. B100-B103.

Ellersieck, Inyo, Blanchard, D.C., Curtis, S.M., Mayfield, C.F., and Tailleur, I.L., 1984, Kivivik Creek--A possible zinc-lead-silver occurrence in the Kuna Formation, western Baird Mountains, Alaska: 868, p. 16-17.

Ellersieck, I.F., Jansons, Uldis, Mayfield, C.F., and Tailleur, I.L., 1982, The Story Creek and Whoopee Creek lead-zinc-silver occurrences, western Brooks Range, Alaska: 844 , p. 35-38.

Ellersieck, Inyo, Mayfield, C.F., Tailleur, I.L., and Curtis, S.M., 1979, Thrust sequence in the Misheguk Mountain quadrangle, Brooks Range, Alaska: 804-B, P. B8.

Ellersieck, Inyo, Tailleur, I.L., Mayfield, C.F., and Curtis, S.M., 1979, A new find of Upper Cretaceous or Tertiary sedimentary rocks in the Noatak Valley: 804-B, p. B13.

Elliott, R.L., Koch, R.D., and Robinson, S.W., 1981, Age of basalt flows in the Blue River valley, Bradfield Canal quadrangle: 823-B, P. B115-B116.

Erdman, J.A., and Motooka, J.M., 1985, Biogeochemical response at the Greens Creek massive sulfide deposit, Admiralty Island: 945, p. 88-91.

Evenson, E.B., Stephens, G.C., Curtin, G.C., and Tripp, R.B., 1982, Geochemical exploration using englacial debris: 844, P. 108-109.

Evenson, E.B., Stephens, G.C., and Detra, D.E., 1985, Bedrock mapping of remote areas using moraine debris from active glaciers, Mt. Hayes and Healy quadrangles: 967 , p. 55-56.

Evenson, E.B., Stephens, G.C, Neher, F.R., King, H.D., and Detra, D.E., 1984, Mineral exploration and reconnaissance bedrock mapping using active alpine glaciers, Mount Hayes and Healy quadrangles, southern Alaska: 868, p. 94-95.

Feulner, A.J., and Williams, J.R., 1981, Further notes on the ground-water supply beneath Selim Creek near Cape Lisburne, northwestern Alaska: 823-B, p. B12-B14.

Filipek, L.H., 1984, The possible siginificance of diagenetic remobilization of ore elements in the mud-flat estuarine environment: 939, p. 96-100. 
Filipek, L.H., Botinelly, Theodore, and Fick1in, W.H., 1985, Lack of relation between the tidal-flat environment and upstream mineralization, Petersburg quadrangle: 945, P. 92-95.

Fisher, M.A., 1982, Preliminary interpretation of geophysical data over the projected offshore location of the Kaltag fault: 844, p. 136-139.

Fisher, M.A., Holmes, M.L., and Patton, W.W., Jr., 1981, Preliminary interpretation of the geologic structure beneath the northern Bering Sea shelf, including Norton Basin: 823-B, p. B118-B121.

Folger, P.F., Goldfarb, R.J., Bailey, E.A., O'Leary, R.M., and Sutley, S.J., 1985, Use of stream-sediment insoluble residues in geochemical exploration for carbonate-hosted mineral deposits in the Baird Mountains: 967, p. 5-8.

Folger, P.F., Goldfarb, R.J., and Schmidt, J.M., 1987, Preliminary evaluation of geochemical anomalies in the Baird Mountains quadrangle, Alaska: 998, p. 31-34.

Ford, A.B., and Brew, D.A., 1977, Truncation of regional metamorphic zonation pattern of the Juneau, Alaska, area by the Coast Range batholith: 751-B, P. B85-B87. 1977, Chemical nature of Cretaceous greenstone near Juneau, Alaska: 751-B, p. B88-B90.

1978, Minor-metal content of Cretaceous greenstone near Juneau, Alaska: 772-B, p. B85-B88.

1981 , Orthogneiss of Mount Juneau--An early phase of Coast Mountains plutonism involved Barrovian regional metamorphism near Juneau: 823-B, p. B99-B102. 1987, The Wright Glacier volcanic plug and dike swarm, southeastern Alaska: 998, p. 116-118.

Foster, H.L., 1981, A minimum age for Prindle Volcano, Yukon-Tanana Upland: 823-B, P. B37-B 38 .

Foster, H.L., and Cushing, G.W., 1985, Tertiary(?) folding in the Tanacross quadrangle: $945, \mathrm{p} .38-40$.

Foster, H.L., Cushing, G.W., Weber, F.R., Jones, D.L., Murchey, Benita, and Blome, C.D., 1984, Late Paleozoic and early Mesozoic radiolarians in the Circle quadrangle, east-central Alaska: 868, p. 62-64.

Foster, H.L., Jones, D.L., Keith, T.E.C., Wardlaw, Bruce, and Weber, F.R., 1978, Late Paleozoic radiolarians and conodonts found in chert of $B i g$ Delta quadrangle: $772-B$, p. B34-B36.

Foster, H.L., and Keith, T.E.C., 1987, Preliminary geology, including the Tintina fault system, of part of the southwestern Charley River quadrangle, Alaska: 998, p. 59-61.

Foster, H.L., and O'Leary, R.M., 1982, Gold found in bedrock of Lost Chicken Creek gold placer mine, Fortymile area, Alaska: 844, p. 62-63.

Foster, H.L., and Weber, F.R., 1976, Reconnaissance geologic mapping in the eastern Big Delta quadrangle: 733, p. 34-36.

Foster, H.L., Weber, F.R., and Dusel-Bacon, Cynthia, 1977, Gneiss dome in the Big Del ta C-4 quadrangle, Yukon-T anana Upland, Alaska: 751-B, p. B33.

Foster, H.L., Weber, F.R., and Dutro, J.T., Jr., 1984, Paleozoic limestones of the Crazy Mountains and vicinity, Circle quadrangle, east-central Alaska: 868, p. 60-62.

Foster, H.L., Weber, F.R., and Keith, T.E.C., 1979, Metamorphic rock units of the southern part of the Circle quadrangle, east-central Alaska: 804-B, P. B54-B55.

Frank, C.O., and Zimmerman, Jay, 1982, Petrography of nonultramafic rocks from the Avan Hills complex, De Long Mountains, Alaska: 844, p. 22-27.

Freethey, Geoffrey, 1979, Sources of water for a confined aquifer at Anchorage: 804-B, P. B 106 .

Fuis, G.S., and Ambos, E.L., 1986, Deep structure of the Contact fault and Prince William terrane--Preliminary results of the $1985 \mathrm{TACT}$ seismic-refraction survey: 978, p. 41-45. 
Fuis, G.S., Ambos, E.L., Mooney, W.D., Page, R.A., and Campbe11, D.L., 1985, Preliminary results of TACT 1984 seismic-refraction survey of southern Alaska: 967 , p. 56-60.

Galloway, J.P., 1982, Grain-size analyses of 20 eolian sand samples from northern Alaska: 844 , p. 51-53.

Galloway, J.P., and Koster, E.A., 1984, Comparison of grain-size statistics from two northern Alaska dune fields: 868, p. 20-21.

Gamble, B.M., Ashley, R.P., and Pickthorn, W.J., 1985, Preliminary study of lode gold deposits, Seward Peninsula: 967, p. 27-29.

Gehrels, G.E., Brew, D.A., and Saleeby, J.B., 1984, Progress report on U/Pb (zircon) geochronologic studies in the Coast plutonic-metamorphic complex east of Juneau, southeastern Alaska: 939, p. 100-102.

Gehrels, G.E., Saleeby, J.B., and Berg, H.C., 1984, Geologic framework of Paleozoic rocks on southern Annette and Hotspur Islands, southern Alexander terrane: 868, p. $113-115$.

1984, Progress in geologic studies of southern Prince of Wales Island, southern Alexander terrane, southeastern Alaska: 939, p. 102-105.

Gehrels, G.E., and Taylor, H.P., Jr., 1984, Fossil hydrothermal systems in the Ketchikan area, southeastern Alaska: 868, p. 134-136.

Giovanetti, Dennis, and Bird, K.J., 1978, Geophysical profiles through the ShaviovikEchooka River region: 772-B, p. B32-B33.

Goldfarb, R.J., 1984, A preliminary geochemical interpretation of the Chugach Wilderness, southern Alaska: 868, p. 89-92.

Goldfarb, R.J., Folger, P.F., Smaglik, S.M., and Tripp, R.B., 1984, A statistical interpretation of geochemical data from Chugach National Forest: 939, p. 47-50.

Goldfarb, R.J., Light, T.D., and Leach, D.L., 1986, Nature of the ore fluids at the Alaska-Juneau gold deposit: 978 , p. 92-95.

Grantz, Arthur, Boucher, Gary, and Whitney, O.T., 1976, Possible solid gas hydrate and natural gas deposits beneath the continental slope of the Beaufort Sea: 733 , p. 17.

Gray, J.E., Church, S.E., and Delevaux, M.H., 1986, Lead-isotope results from goldbearing quartz veins from Valdez and Orca Groups, Chugach National Forest: 978, p. 45-50.

Grome, Sherman, and Hillhouse, J.W., 1981, Paleomagnetic evidence for northward movement of the Chugach terrane, southern and southeastern Alaska: 823-B, p. B70-B72.

Grybeck, Donald, and Brew, D.A., 1979, Mineral resource evaluation methods used in Glacier Bay National Monument Wilderness Study Area, southeastern Alaska: 804-B, P. B110-B 112 .

Grybeck, Donald, Brew, D.A., Johnson, B.R., and Nutt, C.J., 1977, Ultramafic rocks in part of the Coast Range batholithic complex, southeastern Alaska: 751-B, p. B82-B85.

Grybeck, D.J., Cathral1, J.B., LeCompte, J.R., and Cady, J.W., 1985, Buried felsic plutons in Upper Devonian redbeds, central Brooks Range: 945, p. 8-10.

Grybeck, Donald, and Nokleberg, W.J., 1979, Metallogeny of the Brooks Range, Alaska: $804-B$, p. B19-B22.

Hamilton, T.D., 1977, Surficial geology of the east-central Brooks Range: 751-B, p. B15-B16.

1978, Late Cenozoic stratigraphy of the south-central Brooks Range: 772-B, p. B36-B 38 .

1979, Late Cenozoic glaciations and erosion intervals, north-central Brooks Range: $804-B$, P. B 27-B29.

1981, Episodic Holocene alluviation in the central Brooks Range--Chronology, correlations, and climatic implications: 823-B, p. B21-B24. 
Hamilton, T.D., Ashley, G.M., Reed, K.M., and Van Etten, D.P., 1984, Stratigraphy and sedimentology of Epiguruk Bluff--A preliminary account: 939, p. 12-14.

Hamilton, T.D., and Bischoff, J.L., 1984, Uranium-series dating of fossil bones from the Canyon Creek vertebrate locality in central Alaska: 939, p. 26-29.

Hamilton, T.D., and Hopkins, D.M., 1982, Correlation of northern Alaska glacial deposits--A provisional stratigraphic framework: 844, p. 15-18.

Hamilton, T.D., Lancaster, G.A. and Trimble, D.A., 1987, Glacial advance of late Wisconsin (Itkillik II) age in the upper Noatak River Valley--A radiocarbondated stratigraphic record: 998 , p. 35-39.

Hamilton, T.D., and Thorson, R.M., 1976, Surficial geologic mapping in the Philip Smith Mountains and Chandalar quadrangles, Brooks Range: 733, p. 9-10.

Hamilton, T.D., and Van Etten, D.P., 1984, Late Pleistocene glacial dams in the Noatak Valley: 868 , p. 21-23.

Hessin, T.D., 1982, Geochemical studies in the West Chichagof-Yakobi Wilderness: 844, p. $135-136$.

Hildreth, Wes, Fierstein, J.E., Grunder, Anita, and Jager, Larry, 1984, The 1912 eruption in the Valley of Ten Thousand Smokes, Katmai National Park--A summary of the stratigraphy and petrology of the ejecta: 868, p. 37-39.

Hillhouse, J.W., and Grome, Sherman, 1981, Paleolatitude of Triassic basalt in the Clearwater Mountains, south-central Alaska: 823-B, p. B55-B56.

1981 , Paleomagnetic investigation in the Chulitna terrane, south-cental Alaska: 823-B, P. B58-B61.

1982 , Cretaceous overprint revealed by paleomagnetic study in the northern Brooks Range: 844 , p. 43-46.

1984, Paleomagnetic latitude of Paleocene volcanic rocks of the Cantwell

Formation, central Alaska: 868 , p. 80-82.

1985, Paleomagnetism of sedimentary rocks, Prince William and Yakutat terranes: 967 , p. 60-62.

Hillhouse, J.W., Grome, Sherman, and Csejtey, Bela, Jr., 1984, Paleomagnetism of Early Tertiary volcanic rocks in the northern Talkeetna Mountains: 939, p. 50-52.

Himelberg, G.R., Brew, D.A., and Ford, A.B., 1985, Ultramafic bodies in the Coast plutonic-metamorphic complex near Skagway, southeastern Alaska: 967, p. 92-93. 1986, Chemical composition of olivine and orthopyroxene in peridotite of the Coast plutonic-metamorphic complex near skagway: 978, p. 95-98. 1986, The occurrence and chemical composition of chloritoid in the metamorphic rocks of the Coast plutonic-metamorphic complex: 978, p. 99-102.

Himmelberg, G.R., Ford, A.B., and Brew, D.A., 1984, Progressive metamorphism of pelitic rocks in the Juneau area, southeastern Alaska: 868, p. 131-134. 1984, Reaction isograds in pelitic rocks of the Coast plutonic-metamorphic complex near Juneau, Alaska: 939, p. 105-108.

Himelberg, G.R., Ford, A.B., Brew, D.A., and Van Horn, Stephen, Chemical zonation of garnet in pelitic rocks of the Coast plutonic-metamorphic complex near Juneau: 945 , p. $91-92$.

Hoare, J.M., and Coonrad, W.L., 1976, Atomodesma in southwestern Alaska: 733, p. 44. 1977, Blue amphibole occurrences in southwestern Alaska: 751-B, p. B39-B40. 1978, New geologic map of the Goodnews-Hagemeister quadrangles region, Alaska: $772-B$, p. B50-B55.

1978, Lawsonite in southwestern Alaska: 772-B, P. B55-B57. 1979, The Kanektok metamorphic complex, a rootless belt of Precambrian rocks in southwestern Alaska: 804-B, p. B72-B74.

Hoare, J.M., and Jones, D.L., 1981, Lower Paleozoic radiolarian chert and associated rocks in the Tikchik Lakes area, southwestern Alaska: 823-B, p. B44-B45. 
Hoffman, J.D., 1987, An application of oblique rotation R-Mode factor analysis in the Mount Hayes quadrangle, Alaska abstract : 998, p. 108.

Hopkins, D.M., Hartz, R.W., and Robinson, S.W., 1979, Record of a prehistoric storm surge in the Wainwright Inlet-Kuk River area: 804-B, P. B29-B31.

Hopkins, D.M., and Robinson, S.W., 1979, Radiocarbon dates from the Beaufort and Chukchi Sea coasts: 804-B, P. B44-B46.

Hudson, Travis, 1979, Plutonism and regional geology in southern Alaska: 804-B, P. B86-B88.

Hudson, Travis, Barker, Fred, and Arth, Joseph, 1978, Tin-granites of Seward Peninsula: 772-B, P. B44-B45.

Hudson, Travis, Dixon, Kirk, and Plafker, George, 1982, Regional uplift in southeastern Alaska: 844, p. 132-135.

Hudson, Travis, Elliott, R.L., and Smith, J.G., 1977, Investigations of the Wilson Arm molybdenite deposit: 751-B, p. B74. 1978, Chemistry of Quartz Hills intrusive rocks, Ketchikan quadrangle: 772-B, P. B83-B85.

Hudson, Travis, Foster, H.I., and Weber, F.R., 1977, The Shaw Creek fault, eastcentral Alaska: 751-B, P. B33-B34.

Hudson, Travis, and Mays, R.E., 1976, Trace-element composition of biotite from a tin-granite complex, Seward Peninsula: 733, p. 36-37.

Hudson, Travis, and Plafker, George, 1978, Kigluaik and Bendeleben faults, Seward Peninsula: 772-B, P. B47-B50. 1981, Emplacement of the Crillon-La Perouse pluton, Fairweather Range: 823-B, P. B90-B94.

Hudson, Travis, Plafker, George, and Dixon, Kirk, 1982, Horizontal offset history of the Chatham Strait fault: 844, p. 128-132.

Hudson, Travis, Plafker, George, and Rubin, Meyer, 1976, Uplift rates of marine terrace sequences in the Gulf of Alaska: 733, p. 11-13.

Hudson, Travis, and Weber, F.R, 1977, The Donnelly Dome and Granite Mountain faults, south-central Alaska: 751-B, P. B64-B66.

Huffman, A.C., and Ahlbrandt, T.S., 1979, The Cretaceous Nanushuk Group of the western and central North Slope, Alaska: 804-B, p. B46-B50.

Huffman, A.C., Kirk, A.R., and Molenaar, C.M., 1982, Uranium investigations-Northeastern Alaska: 844, p. 41-43.

Hummel, C.L., 1976, Revised interpretation of regional geological controls of mineralization in southwest Seward Peninsula, west-central Alaska: 733, p. 37-39.

Hunt, S.J., 1984, Preliminary study of a zoned leucocratic-granite body on central Etolin Island, southeastern Alaska: 868, p. 128-130.

Hunt, S.J., and Brew, D.A., 1986, Geometric structural analysis of part of the Coast plutonic-metamorphic complex east of Wrangell: 978, p. 102-108.

Hunter, R.E., and Fox, J.E., 1976, Interpretation of depositional environments in the Fortress Mountain Formation, central Arctic Slope: 733 , p. 30-31.

Johnson, B.R., Forn, C.L., Hoffman, J.D., Brew, D.A., and Nutt, C.J., 1977, Geochemical sampling of stream sediments, Tracy Arm, southeastern Alaska: $751-B$, P. B80-B82.

Johnson, B.R., Miller, T.P., and Karl, Susan, 1979, Uranium-thorium investigations of the Darby pluton, Seward Peninsula, Alaska: 804-B, P. B68-B70.

Johnson, Kirk, Mitchell, Heidi-Lynn, and Nelson, C.H., 1984, Gray whale feeding ecology and sea-floor interaction in the northern Bering sea--Preliminary results: 939 , p. 127-132.

Johnston, D.A., 1979, Onset of volcanism at Augustine Volcano, lower Cook Inlet: 804-B, P. B 78-B80. 1979, Volcanic gas studies at Alaskan volcanoes: 804-B, P. B83-B84. 
Johnston, D.A., and Detterman, R.L., 1979, Revision of the recent eruption history of Augustine Volcano--Elimination of the "1902 eruption": 804-B, p. B80-B83.

Jones, D.L., Berg, H.C., Coney, P.J., and Harris, Anita, 1981, Structural and stratigraphic significance of Upper Devonian and Mississippian fossils from the Cannery Formation, Kupreanof Island, southeastern Alaska: 823-B, P. B109-B112.

Jones, D.L., Silberling, N.J., Berg, H.C., and Plafker, George, 1982, Tectonostratigraphic terrane map of Alaska: 844, p. $1-5$.

Jones, D.L., Silberling, N.J., Chapman, R.M., and Coney, Peter, 1984, New ages of radiolarian chert from the Rampart district, east-central Alaska: 868, P. 39-43.

Jones, D.L., Silberling, N.J., Wardlaw, Bruce, and Richter, Don, 1981, Revised ages of Paleozoic and Mesozoic rocks in the Talkeetna quadrangle, south-central Alaska: 823-B, P. B46-B49.

Jones, G.M., Menzie, W.D., and Foster, H.L., 1985, Statistical discrimination between potential tin- and uranium-bearing areas in east-cental Alaska on the basis of stream-sediment trace-element geochemistry: 945, p. 40-46.

Jones, S.H., 1976, Hydrologic reconnaissance of TAPS haulroad: 733, p. 9. 1978, Streamflow in NPRA, 1977: 772-B, p. B29.

Kachadoorian, Reuben, Crory, F.E., and Berg, D.L., 1978, Studies of proposed airfields at the Inigok and Tunalik well sites, NPRA: 772-B, P. B22-B24.

Kachadoorian, Rueben, Crory, F.E., and Berg, D.L., 1979, Design of airfields in National Petroleum Reserve in Alaska: 804-B, P. B51-B52.

Kachadoorian, Reuben, and Moore, H.J., 1979, Watana and Devils Canyon damsites, Susitna River, Alaska: 804-B, P. B99-B101.

Kachadoorian, Reuben, and Ovenshine, A.T., 1984, Natural restoration from the effects of the 1964 earthquake at Portage, southern Alaska: 868, p. 109-110.

Kachadoorian, Reuben, Ovenshine, A.T., and Bartsch-Winkler, Sus an, 1977, Late Wisconsin history of the south shore of Turnagain Arm, Alaska: 751-B, p. B49-B50.

Karl, H.A., Carlson, P.R., and Lamb, Beth, 1982, Sediment waves in the head of Navarinsky, Pervenets, and Zhemchug Canyons, northwestern Bering Sea: 844, P. 141-143.

Karl, H.A., Gardner, J.V., and Huggett, Quentin, 1987, GLORIA images of Zhemchug Canyon and Bering channel-fan system, Bering Sea: 998, p. 147-151.

Karl, Susan, 1984, Recognition of the Burnt Island Conglomerate on the Screen Islands, southeastern Alaska: 868 , p. 115-117.

Karl, Susan, and Brew, D.A., 1984, Migmatites of the Coast plutonic-metamorphic complex, southeastern Alaska: 939, p. 108-111.

Karl, Susan, Decker, J.E., and Johnson, B.R., 1982, Discrimination of Wrangellia and the Chugach terrane in the Kelp Bay Group on Chichagof and Baranof Islands, southeastern Alaska: 844, p. 124-128.

Karl, Susan, Decker, John, and Jones, D.L., 1979, Early Cretaceous radiolarians from the McHugh Complex, south-central Alaska: 804-B, P. B88-B90.

Karl, Susan, and Hoare, J.M., 1979, Results of a preliminary paleomagnetic study of volcanic rocks from Nuyakuk Lake, southwestern Alaska: 804-B, P. B74-B78.

Karl, S.M., Schmidt, J.M., and Folger, P.F., 1985, Selected anomalous rock and sediment samples from central and northwestern Baird Mountain quadrangle: 967 , P. 8-13.

Kaufman, D.S., 1985, Windy Creek and Crater Creek faults, Seward Peninsula: 945, p. 22-24.

Keith, T.E.C., 1984, Preliminary observations on fumarole distribution and al teration, Valley of 10,000 Smokes, Alaska: 939, p. 82-85.

Keith, T.E.C., Barnes, Ivan, and Foster, H.L., 1981, Laumontite occurrence in the Circle A-1 quadrangle, Alaska: 823-B, p. B28-B29. 
Keith, T.E.C., and Foster, H.L., 1977, U1tramafic rocks near Volkmar Lake, Big Delta quadrangle, Yukon-T anana Upland, Alaska: 751-B, p. B32-B33.

1979, Big Windy Creek hot springs, Circle A-1 quadrangle, Alaska: 804-B, P. B55-B57.

Keith, T.E.C., Page, N.J., Oscarson, R.L., and Foster, H.L., 1987, Platinum-group element concentrations in a biotite-rich clinopyroxenite suite, Eagle C-3 quadrangle, Alaska: 998, p. 62-66.

Keith, T.E.C., Presser, T.S., and Foster, H.L., 1981, New chemical and isotope data for the hot springs along Big Windy Creek, Circle A-l quadrangle, Alaska: $823-B$, P. B25-B28.

King, H.D., 1982, Reconnaissance geochemical survey of the Healy quadrangle: 844, p. $107-108$.

1984, Geochemical survey of the Solomon and Bendeleben quadrangles, Seward Peninsula, Alaska: 939, p. 33-37.

Koch, R.D., Brew, D.A., and Ford, A.B., 1987, Newly discovered molybdenite occurrence near Boundary Creek, Coast Mountains, southeastern Alaska: 998, p. 124-125.

Koch, R.D., and Elliott, R.L., 1984, Late 0ligocene gabbro near Ketchikan, southeastern Alaska: 868 , p. 126-128.

Koch, R.D., Elliott, R.L., Smith, J.G., and Berg, H.C., 1977, Metamorphosed trondjhemite of the Alexander terrane in Coast Range plutonic complex: 751- $B$, P. B72-B74.

Koch, R.D., Smith, J.G., and Elliott, R.L., 1977, Miocene or younger strike-slip(?) fault at Canoe Passage, southeastern Alaska: 751-B, P. B76.

Krumhardt, Andrea, 1979, Geohydrology of Fairbanks North Star Borough: 804-B, P. B59.

Krumhardt, Andrea, 1982, Geohydrology of the Fairbanks North Star Borough, Alaska: 844, p. 68-69.

Lachenbruch, A.H., and Marshall, B.V., 1978, A simple target model for offshore permafrost at Prudhoe Bay: 772-B, P. B30-B32.

Lachenbruch, A.H., Sass, J.H., Marshall, B.V., Moses, T.H., Jr., Munroe, R.J., and Smith, E.P., 1984, Geothermal studies in Alaska--Conditions at Prudhoe Bay: 868, p. 19-20.

Lahr, J.C., and Blackford, Michael, 1976, Gulf of Alaska seismicity: 733, p. 55.

Lahr, J.C., Page, R.A., Fogleman, K.A., and Stephens, C.D., 1985, New evidence for activity on the Talkeetna segment, Castle Mountain-Caribou fault system--The 1984 Sutton earthquake: 967, p. 62-63.

Laird, Jo, and Foster, H.L., 1984, Description and interpretation of a mylonitic foliated quartzite unit and feldspathic quartz wacke (grit) unit in the Circle quadrangle, Alaska: 939, p. 29-33.

Laird, Jo, Foster, H.L., and Weber, F.W., 1984, Amphibolite eclogite in the Circle quadrangle, Yukon-T anana Upland, Alaska: 868, p. 57-60.

Lankford, S.M., and Magoon, L.B., 1978, Petrography of the Upper Jurassic through Oligocene sandstones in the Cape Douglas area, lower Cook Inlet: 772-B, P. B60-B62.

Lawver, L.A., Lachenbruch, A.H., and Moses, T.H., Jr., 1979, Status of regional heatflow studies in Alaska: $804-B$, P. B5-B7.

LeCompte, J.R., and Steele, W.C., 1981, Landsat data interpretation in the southcentral Brooks Range and in southeastern Alaska: 823-B, p. B1-B3.

LeCompte, J.R., Steele, W.C., and Albert, N.R.D., 1984, Summary of Landsat quadrangle studies in Alaska: 868 , p. 1-4.

LeHuray, A.P., Church, S.E., and Nokleberg, W.J., 1985, Lead isotopes in sulfide deposits from the Jarvis Creek Glacier and Wrangellia terranes, Mount Hayes quadrangle, eastern Alaska Range: 945, p. 72-73. 
LeHuray, A.P., Stowell, H.S., and Church, S.E., 1985, Lead isotopes from volcanogenic massive sulfide deposits in the Alexander terrane: 945, p. 95-96.

Leonard, K.R., and Huber, D.F., 1987, Status of Alaska Mineral Resources Data System: 998, P. $15-18$.

Light, T.D., 1985, Preliminary interpretation of factor analysis of geochemical data from the Healy quadrangle: 967, p. 64-66.

Light, T.D., Cady, J.W., Weber, F.R., McCammon, R.B., and Rinehart, C.D., 1987, Sources of placer gold in the southern part of the White Mountains Recreation Area, east-central Alaska: 998, p. 67-69.

Lins, H.F., Jr., 1978, Analysis of remotely sensed data for use in evaluating the onshore impacts of offshore petroleum development at Kenai, Alaska: 772-B, p. B76-B 78.

Lisowski, Michael, Savage, J.C., and Prescott, W.H., 1984, Horizontal-strain observations in the Shumagin Island and Yakataga seismic gaps, Alaska: 868, p. $9-10$.

Loney, R.A., and Himmelberg, G.R., 1984, Preliminary report on ophiolites in the Yuki River and Mount Hurst areas, west-central Alaska: 868, p. 27-30. 1985, Distribution and character of the peridotite-layered gabbro complex of the southeastern Yukon-Koyukuk ophiolite belt: 945, p. 46-48. 1985, Ophiolitic ultramafic rocks of the Jade Mountains-Cosmos Hills area, southwestern Brooks Range: 967 , p. 13-15.

Loney, R.A., Himmelberg, G.R., and Shew, Nora, 1987, Salt Chuck palladium-bearing ultramafic body, Prince of Wales Island: 998, p. 126-127.

Long, C.L., and Thompson, Bill, 1986, Audio-magnetotelluric resistivity traverses in the Baird Mountains: 978, p. 13-16.

Lull, J.S., and Plafker, George, 1985, Petrography of sandstone from the Yakutat Group, Malaspina district, southern Alaska: 945, p. 73-77.

Madison, R.J., 1976, Alaskan quality-of-water station network (NASQAN): 733, p. 7. 1976, Hydrological studies for the Alaskan Air Command: 733, p. 30.

Magoon, L.B., and Claypool, G.E., 1978, Organic geochemistry of rocks from three NPRA wells: 772-B, P. B25-B26.

Magoon, L.B., Egbert, R.M., and Petering, George, 1978, Upper Jurassic and Cretaceous rocks of the Kamishak Hills-Douglas River area, lower Cook Inlet: 772-B, p. B57-B59.

Mammay, S.H., and Reed, B.L., 1984, Permian plant megafossils from the conglomerate of Mount Dall, central Alaska Range: 868, p. 98-102.

Mankinen, E.A., and Plafker, George, 1987, Paleomagnetic evidence for a latest Pliocene and early Pleistocene age of the upper Yakataga Formation on Middleton Island, Alaska: 998 , p. 132-136.

Marincovich, Louie, Jr., 1976, Miocene mollusks from the Topsy Formation, Lituya district: 733 , p. 58 .

Marincovich, Louie, Jr., Brouwers, E.M., and Carter, L.D., 1984, Early Tertiary marine fossils from Ocean Point, Arctic Coastal Plain, and their relation to Arctic Ocean paleogeography: 939, p. 15-17.

Marlow, M.S., 1977, Resource assessment and geophysical exploration of the southern Bering Sea shelf: 751-B, P. B97-B98.

Marlow, Mike, 1978, Navarin basin, northwest Bering Sea shelf: 751-B, p. B96.

Marlow, M.S., Carlson, P.R., Dadisman, S.V., Rearic, D.M., Maple, E.J., and Parson, L.M., 1987, GLORIA side-scan and geophysical surveys of the central Bering Sea in 1986: 998, p. 152-156.

Marsh, S.P., 1976, Geochemical reconnaissance of the Chandalar quadrangle: 733, p. 33-34.

Mayfield, C.F., 1976, Metamorphism in the southwestern Brooks Range: 733, p. 31-32. 
Mayfield, C.F., Curtis, S.M., Ellersieck, I.F., and Tailleur, I.L., 1979, The Ginny Creek zinc-lead-silver and Nimiuktuk barite deposits, northwestern Brooks Range, Alaska: $804-B$, P. B11-B12.

Mayfield, C.F., Silberman, M.L., and Tailleur, I.L., 1982, Precambrian metamorphic rocks from the Hub Mountain terrane, Baird Mountains quadrangle, Alaska: 844, p. $18-22$.

Mayfield, C.F., Tailleur, I.L., Mull, C.G., and Silberman, M.L., 1978, Granitic clasts from Upper Cretaceous conglomerate in the northwestern Brooks Range: $772-B$, P. B11-B13.

Mayo, L.R., 1977, Glacier research: 751-B, P. B5-B6.

McClellan, P.H., Fisher, M.A., von Heune, Roland, and Moore, G.W., 1982, Sumary and discussion of microfossil biostratigraphy in the western Gulf of Alaska: 844, p. 148-151.

McClellan, P.H., and Giovanetti, D.M., 1981, New invertebrate fossils, but still no land vertebrates from nonmarine Tertiary rocks of the Kenai Peninsula: 823-B, p. B84-B86.

McLean, Hugh, 1978, Tertiary sedimentary rocks of the Alaska Peninsula between Pavl of $B$ ay and False Pass; their geology and petroleum potential: 772-B, P. B65.

McCoy, G.A., 1976, Limnological investigations in southeastern Alaska: 733, p. 61. 1977, Fisheries enhancement studies--Limnological studies in southeastern Alaska and water quality measurements along the TAPS route during pipeline construction: 751-B, P. B7-B8. 1982, Nutrient limitation in two arctic lakes: 844, p. 53.

Meckel, J.P., 1976, Environmental data collection along proposed Canadian gas pipeline along coastal route in Alaska: 733, p. 23.

Meier, M.F., Mayo, L.R., Post, Austin, Sikonia, W.G., and Trabant, D.C., 1979, Stability of Columbia Glacier, Alaska: 804-B, P. B106-B107.

Menzie, W.D., Foster, H.L., and Mosier, D.L., 1981, Metalliferous mineral resource potential of the Big Delta quadrangle: 823-B, P. B38-B39.

Menzie, W.D., Reed, B.L., and Keith, T.E.C., 1986, Lime Peak--An evolved granite with tin-enriched alteration: 978 , p. 25-27.

Miller, J.W., and Detterman, R.L., 1985, The Buchia zones in upper Jurassic rocks on the Alaska Peninsula: 945, p. 51-53.

Miller, J.W., Detterman, R.L., and Case, J.E., 1982, Lower Cretaceous (Albian) rocks on the Alaska Peninsula: 844, p. 83-86.

Miller, M.L., and Bundtzen, T.K., 1985, Metamorphic rocks in the western Iditarod quadrangle, west-central Alaska: 945, p. 24-28.

Miller, M.L., Dumoulin, J.A., and Nelson, S.W., 1984, A transect of metamorphic rocks along the Copper River, Cordova, and Valdez quadrangles, Alaska: 939, p. 52-57.

Miller, T.P., and Johnson, B.R., 1978, An occurrence of parsonite, a secondary uranium mineral, in alaskite of the Wheeler Canyon pluton: 772-B, p. B42-B44.

Miller, T.P., and Lanphere, M.A., 1981, K-Ar age measurements on obsidian from the Little Indian River locality in interior Alaska: 823-B, P. B39-B42.

Miller, T.P., and Smith, R.L., 1976, "New" volcanoes in the Aleutian volcanic arc: 733 , p. 11 .

1976, Two caldera-forming eruptions on Umnak Island, eastern Aleutian Islands: 733, p. 45.

1976, Ash flows associated with Wrangell Volcano: 733, p. 52.

Miyaoka, R.T., and Dover, J.H., 1985, Preliminary study of shear sense in mylonites, eastern Ray Mountains, Tanana quadrangle: 967, p. 29-32.

Molenaar, C.M., 1981, Depositional history of the Nanushuk Group and related strata: $823-B$, P. B4-B6. 
Molenaar, C.M., Egbert, R.M., and Krystinik, L.F., 1982, Depositional facies and reservoir potential of the Fortress Mountain Formation, central North Slope: 844, p. $32-33$.

Molenaar, C.M., Huffman, A.C., and Kirk, A.R., 1982, Cretaceous-lower Tertiary depositional relations, northeastern Alaska: 844, p. 33-35.

Mo11, E.J., and Patton, W.W., Jr., 1982, Preliminary report on the Late Cretaceous and early Tertiary volcanic and related plutonic rocks in western Alaska: 844, p. 73-76.

Molnia, B.F., 1981, Distribution of gas-charged sediment and pockmarks in the northeastern Gulf of Alaska, Yakutat Bay to Cross Sound: 823-B, P. B125. 1981 , Depth changes in Icy Bay, Alaska, caused by sedimentation and melting of ice-cored moraine: 823-B, P. B125-B128.

Molnia, B.F., and Carlson, P.R., 1976, Surface sedimentary units of the northern Gulf of Alaska continental shelf: 733, p. 56-57.

Molnia, B.F., and Rappeport, M.L., 1982, Mosaic of pockmarked sea-floor area near the Alsek River, northeastern Gulf of Alaska: 844, p. 146-148.

Moore, T.E., and Nilsen, T.H., 1985, Sedimentology of meandering-stream cycles, upper part of the Ear Peak Member of the Kanayut Conglomerate, central Brooks Range: 967 , p. 15-19.

Moore, T.E., Nilsen, T.H., Grantz, Arthur, and Tailleur, I.L., 1984, Parautochthonous Mississippian marine and nonmarine strata, Lisburne Peninsula, Alaska: 939, P. 17-21.

Morgan, A.V., Morgan, Anne, and Carter, L.D., 1979, Paleoenvi ronmental interpretation of a fossil insect fauna from bluffs along the lower Colville River, Alaska: $804-B$, P. B41-B44.

Morrissey, L.A., and Ennis, R.A., 1979, Vegetation mapping of the National Petroleum Reserve in Alaska using Landsat digital data: 804-B, P. B50-B51.

Mul1, C.G., 1977, Apparent south vergent folding and possible nappes in Schwatka Mountains: $751-B$, P. B29-B 30 .

Mul1, C.G., and Kososki, B.A., 1977, Hydrocarbon assessment of the Arctic National Wildlife Refuge, eastern Arctic Slope, Alaska: 751-B, P. B20-B22.

Mu11, C.G., and Nelson, S.W., 1986, Anomal ous thermal maturity data from the Orca Group (Paleocene and Eocene), Katalla-Kayak Island area: 978, P. 50-55.

Mul1, C.G., and Tailleur, I.L., 1977, Sadlerochit(?) Group in the Schwatka Mountains, southcentral Brooks Range: 751-B, P. B27-B29.

Mul1, C.G., Tailleur, I.L., Mayfield, C.F., and Pessel, G.H., 1976, New structural and stratigraphic interpretations, central and western Brooks Range and Arctic Slope: 733 , p. 24-26.

Mullen, M.W., 1987, Petrology and provenance of sandstones of the Naknek Formation, Alaska Peninsula: 998 , p. 86-90.

Mullen, M.W., and Csejtey, Bella, Jr., 1986, Recognition of a Nixon Fork terrane equivalent in the Healy quadrangle: 978, p. 55-60.

Murchey, B.L., Swain, P.B., and Curtis, Steven, 1981, Late Mississippian to Pennsylvanian radiolarian assemblages in the Siksikpuk(?) Formation at Nigu Bluff, Howard Pass quadrangle, Alaska: 823-B, p. B17-B19.

Murphy, J.M., 1987, Early Cretaceous cessation of terrane accretion, northern Eek Mountains, southwestern Alaska: 998 , p. 83-85.

Nauman, J.W., and Kernodle, D.R., 1976, Water quality and benthic invertebrates along the TAPS route: 733 , p. 8 .

Nauman, J.W., Sloan, C.E., and Kernodle, D.R., 1977, Effects of fuel oil leaks on water quality in three streams along the trans-Alaska pipeline: 751-B, P. B7. 1977, Stream relocation and benthic invertebrates in Canyon Slough near Valdez, Alaska: $751-B$, p. B46. 
Nelson, C.H., 1977, Ice gouging and other environmental geologic problems of northern Bering Sea: 751-B, p. B98.

Nelson, C.H., and Creager, J.S., 1976, Displacement of Yukon-derived sediment from northern Bering Sea to southern Chukchi Sea during the Holocene: 733, p. 10-11.

Nelson, C.H., Jenne, E.A., Larsen, B.R., and Sorg, D.H., 1976, Mercury dispersal in Kuskokwim River and Bay: 733, p. 43-44.

Nelson, C.H., Rowland, R.W., and Stoker, S.W., 1976, Sedimentary facies and structures of the northern Bering epicontinental shelf: 733, p. 43.

Nelson, G.L., 1976, North Slope water resources studies: 733, p. 23. 1976, Geohyrdrology of the Fairbanks North Star Borough: 733, p. 34. 1977, North Slope water resources studies: 751-B, p. B31. 1977, Geohydrology of the Fairbanks-North Star Borough: 751-B, P. B36-B37. 1978, Geohydrology of the Fairbanks-North Star Borough: 772-B, P. B38. 1978, Geohydrology of the Delta-Clearwater area: 772-B, P. B38.

Nelson, R.E., 1981, Paleoenvironments during deposition of a section of the Gubik Formation exposed along the lower Colville River, North Slope: 823-B, P. B9-B11.

Nel son, S.W., Blome, C.D. Harris, A.G., Reed, K.M., and Wilson, F.H., 1986, Late Paleozoic and Early Jurassic fossil ages from the McHugh Complex: 978, p. 60-64.

Nelson, S.W., Blome, C.D., and Karl, S.M., 1987, Late Triassic and Early Cretaceous fossil ages from the McHugh complex, southern Alaska: 998, p. 96-98.

Nelson, S.W., and Grybeck, Donald, 1978, The Arrigetch Peaks and Mount Igikpak plutons, Survey Pass quadrangle: 772-B, P. B 7-B9. 1979, Tectonic significance of metamorphic grade distribution, Survey Pass quadrangle, Alaska: 804-B, p. B16-B17.

Nelson, S.W., Nokleberg, W.J., Miller-Hoare, Martha, and Mullen, M.W., 1979, Siniktanneyak Mountain ophiolite: 804-B, p. B14-B16.

Nelson, W.H., Csejtey, Bela, Jr., and Dean, R.M., 1976, Reconnaissance geology of the western Talkeetna Mountains quadrangle: 733, p. 47-48.

Newberry, R.J., and Brew, D.A., 1987, The Alaska-Juneau gold deposit--Remobilized syngenetic versus exotic epigenetic origin: 998, p. 128-131.

Nilsen, T.H., 1982, Accretion model for the Cretaceous Chugach terrane, southern Alaska: 844, p. 93-97. 1984, Miocene back-arc tidal deposits of the Bear Lake Formation, Alaska Peninsula: 939, p. 85-88.

Nilsen, T.H., Brosge, W.P., and Dutro, J.T., Jr., 1985, New reference section of the Noatak Sandstone, Nimiuktuk River, Misheguk Mountain quadrangle, central Brooks Range: 945, p. 10-13.

Nilsen, T.H., Brosge, W.P., Dutro, J.T., Jr., and Moore, T.E., 1981, Depositional model for the fluvial Upper Devonian Kanayut Conglomerate, Brooks Range, Alaska: $823-\mathrm{B}, \mathrm{P}$. B20-B21.

Nilsen, T.H., Brosge, W.P., Moore, T.E., Dutro, J.T., Jr., and Balin, Donna, 1982, Significance of the Endicott Group for tectonic models of the Brooks Range: 844 , p. 28-32.

Nilsen, T.H., and Moore, T.E., 1984, The Kanayut Conglomerate in the westernmost Brooks Range, Alaska: 868 , p. 12-16.

Nilsen, T.H., and Patton, W.W., Jr., 1984, Cretaceous fluvial to deep-marine deposits of the central Yukon-Koyukuk basin, Alaska: 939, p. 37-40.

Nilsen, T.H., Plafker, George, Atwood, D.E., and Hi11, E.R., 1984, Sedimentology of flysch of the upper Mesozoic Yakutat Group, Malaspina district, Alaska: 939, p. 57-60. 
Nokleberg, W.J., Albert, N.R.D., Herzon, P.L., Miyaoka, R.T., and Zehner, R.E., 1981, Recognition of two subterranes within the Wrangellia terrane, southern Mount Hayes quadrangle, Alaska: 823-B, P. B64-B66.

1981 , Cross section showing accreted Andean-type arc and island arc terranes in southwestern Mount Hayes quadrangle, Alaska: 823-B, P. B66-B67.

Nokleberg, W.J., Albert, N.R.D., and Zehner, R.E., 1979, The ophiolite of Tangle Lakes in the southern Mount Hayes quadrangle, eastern Alaska Range--An accreted terrane?: 804-B, P. B96-B98.

Nokleberg, W.J., and Aleinikoff, J.N., 1985, Summary of stratigraphy, structure, and metamorphism of Devonian igneous-arc terranes, northeastern Mount Hayes quadrangle, eastern Alaska Range: 967 , p. 66-71.

Nokleberg, W.J., Aleinikoff, J.N., and Lange, I.M., 1986, Cretaceous deformation and metamorphism in the northeastern Mount Hayes quadrangle, eastern Alaska Range: 978 , p. 64-69.

Nokleberg, W.J., and Lange, I.M., 1985, Volcanogenic massive sulfide occurrences, Jarvis Creek Glacier terrane, western Mount Hayes quadrangle, eastern Alaska Range: $945, \mathrm{p} \cdot 77-80$.

Nokleberg, W.J., Lange, I.M., and Roback, R.C., 1984, Preliminary accretionary terrane model for metallogenesis of the Wrangellia terrane, southern Mount Hayes quadrangle, eastern Alaska Range, Alaska: 939, p. 60-65.

Nokleberg, W.J., Schwab, C.E., Miyaoka, R.T., and Buhrmaster, C.L., 1984, Stratigraphy, petrology, and structure of the Pingston terrane, Mount Hayes $C-5$ and C-6 quadrangles, eastern Alaska Range, Alaska: 868, p. 70-73.

Nokleberg, W.J., Wade, W.M., Lange, I.M., and Plafker, George, 1986, Summary of Geology of the Peninsular Terrane, metamorphic complex of Gulkana River, and Wrangellia Terrane, north-central and northwestern Gulkana quadrangle: 978, p. $69-74$.

Nokleberg, W.J., and Winkler, G.R., 1978, Stratiform zinc-lead mineralization, Drenchwater Creek area, Howard Pass quadrangle, western Brooks Range, Alaska: 772-B, P. B17-B19.

Nokleberg, W.J., Zehner, R.E., and Miyaoka, R.T., 1982, Geologic setting of the Maclaren metamorphic belt, Mount Hayes $A-6$ and $B-6$ quadrangles, eastern Alaska Range, Alaska: 844, p. 97-100.

O'Leary, R.M., and Hoffman, J.D., 1984, Alaskan geochemical field laboratories: 868, p. 10 .

O'Leary, R.M., and MCDanal, S.K., 1982, Alaskan geochemical field laboratories: 844, P. $11-12$.

Osbakken, W.E., 1976, Automated observatory system installed at Sitka Observatory: 733, p. 60 .

Ovenshine, A.T., Bartsch-Winkler, Susan, Rupert, Jeff, and Kachadoorian, Reuben, 1977, Preliminary studies of a 93-m core at Portage, Alaska: 751-B, P. B50-B51.

Ovenshine, A.T., and Kachadoorian, Reuben, 1976, Estimate of time required for natural restoration of the effects of the 1964 earthquake at Portage: 733, p. 53-54.

Page, R.A., Hassler, M.H., Stephens, C.D., and Criley, E.E., 1984, Fault zone geometry of the 1979 St. Elias, Alaska earthquake: 939, p. 65-67.

Page, R.A., Stephens, C.D., Fogleman, K.A., and Maley, R.P., 1985, The Columbia Bay earthquakes of 1983: 945 , P. 80-82.

Palmer, I.F., Bolm, J.G., Flett, T.0., Lyle, W.M., Morehouse, J.A., Riehle, J., and Emel, K.S., 1979, Hydrocarbon reservoir and source rock characteristics from selected areas of western Alaska: 804-B, P. B86.

Palmer, I.F., and Lyle, W.M., 1977, Cooperative stratigraphic project in lower Cook Inlet and Kodiak areas, U.S. Geological Survey and State of Alaska Division of Geological and Geophysical Surveys: 751-B, P. B45-B46. 
Panuska, B.C., Decker, J.E., and Berg, H.C., 1984, A preliminary paleomagnetic study of the Gravina-Nutzotin belt, southern and southeastern Alaska: 868 ,

p. $117-120$.

Patton, W.W., Jr., 1976, Newly discovered Upper Triassic and Lower Cretaceous strata in the northern Kuskokwim Mountains: 733, p. 42-43. 1977, Pre-Ordovician unconformity in central Alaska: 751-B, p. B39. 1978, Juxtaposed continental and oceanic-island arc terranes in the Medfra quadrangle, west-central Alaska: 772-B, P. B38-B39.

Patton, W.W., Jr., and Dutro, J.T., Jr., 1979, Age of the metamorphic complex in the northern Kuskokwim Mountains, west-central Alaska: 804-B, P. B61-B63.

Patton, W.W., Jr., Dutro, J.T., Jr., and Chapman, R.M., 1977, Late Paleozoic and Mesozoic stratigraphy of the Nixon Fork area, Medfra quadrangle, Alaska: 751-B, P. B38-B39.

Patton, W.W., Jr., and Mol1, E.J., 1982, Structural and stratigraphic sections along a transect between the Alaska Range and Norton Sound: 844, p. 76-78. 1984, Reconnaissance geology of the northern part of the Unalakleet quadrangle: 868 , p. 24-27.

Patton, W.W., Jr., Mo11, E.J., Lanphere, M.A., and Jones, D.L., 1984, New age data for the Kaiyuh Mountains, west-central Alaska: 868, p. 30-32.

Phillips, R.L., and Colgan, M.W., 1987, Vibracore stratigraphy of the northeastern Chukchi Sea: 998 , p. 157-160.

Pickthorn, W.J., 1984, Stable isotope study of quartz veins in the Port valdez gold district: 939 , p. $67-70$.

Pickthorn, W.J., Goldfarb, R.J., O'Leary, R.M., Sutley, S.J., and Weaver, Sarah, 1985, Kayak Island--Analysis of a geochemical anomaly: 945, p. 82-83.

Pickthorn, W.J., and Nelson, S.W., 1984, Preliminary reconnaissance sulfur isotope geochemistry of massive sulfide occurrences in the Prince William Sound district: 939 , p. 70-71.

Pickthorn, W.J., and Silberman, M.L., 1984, structural relations and fluid-inclusion data for mineralized and nonmineralized quartz veins in the Port Valdez gold district, Valdez quadrangle, southern Alaska: 868 , p. 86-89.

Plafker, George, and Campbel1, R.B., 1979, The Border Ranges fault in the Saint Elias Mountains: 804-B, p. B102-B104.

Plafker, George, Carlson, P.R., Coonrad, W.L., Hunt, S.J., and Quinterno, Paula, 1979, Geologic implications of 1978 outcrop sample data from the continental slope in the eastern Gulf of Alaska: 804-B, P. B143-B146.

Plafker, George, Harris, A.G., and Reed, K.M., 1985, Early Pennsylvanian conodonts from the Strelna Formation, Chitina Valley: 967, p. 71-74.

Plafker, George, Hudson, Travis, and Jones, D.L., 1978, Upper Triassic radiolarian chert from the Kobuk volcanic sequence in the southern Brooks Range: 772-B, p. B45-B47.

Plafker, George, Hudson, Travis, and Richter, D.H., 1977, Preliminary observations on late Cenozoic displacements along the Totschunda and Denali fault systems: 751-B, P. B67-B69.

Plafker, George, Hudson, Travis, and Rubin, Meyer, 1976, Late Holocene offset features al ong the Fairweather fault: 733, p. 57-58.

Plafker, George, Hudson, Travis, Rubin, Meyer, and Dixon, K.L., 1982, Holocene marine terraces and uplift history in the Yakataga seismic gap near Icy Cape, Alaska: 844, p. 111-115.

Plafker, George, Hudson, Travis, and Silberling, N.J., 1979, Late Triassic fossils from a sequence of volcanic and sedimentary rocks on the Chilkat Peninsula, southeastern Alaska: 804-B, P. B107-B110. 
Plafker, George, Jones, D.L., Hudson, Travis, and Berg, H.C., 1976, The Border Ranges fault system in the Saint Elias Mountains and Alexander Archipelago: 733, p. $14-16$.

Plafker, George, Jones, D.L., and Pessagno, E.A., Jr., 1977, A Cretaceous accretionary flysch and melange terrane along the Gulf of Alaska margin: 751-B, P. B41-B43.

Plafker, George, Keller, Gerta, Nelson, S.W., Dumoulin, J.A., and Miller, M.L., 1985, Summary of data on the age of the Orca Group: 967, p. 74-76.

Plafker, George, Nokleberg, W.J., and Lull, J.S., 1985, Sumary of 1984 TACT geologic studies on the northern Chugach Mountains and southern Copper River basin: 967, p. 76-79.

Plafker, George, Nokleberg, W.J., Lull, J.S., Roeske, S.M., and Winkler, G.R., 1986, Nature and timing of deformation along the Contact fault system in the Cordova, Bering Glacier, and Valdez quadrangles: 978, p. 74-77.

Plafker, George, Richter, D.H., and Hudson, Travis, 1977, Reinterpretation of the origin of inferred Tertiary tillite in the northern Wrangell Mountains, Alaska: 751-B, p. B52-B54.

Plafker, George, Winkler, G.R., Hunt, S.J., Bartsch-Winkler, Susan, Coonrad, W.L., and Quinterno, Paula, 1978, Outcrop samples from the Continental slope in the eastern Gulf of Alaska: 772-B, p. B97-B101.

Poore, R.z., and Bukry, David, 1979, Preliminary report on Eocene calcareous plankton from the eastern Gulf of Alaska continental slope: 804-B, p. B141-B143.

Post, Austin, and Meier, M.F., 1979, Glacier inventories: 804-B, P. B7.

Quinterno, Paula, Carlson, P.R., and Molnia, B.F., 1981, Benthic foraminifers as indicators of the Pleistocene-Holocene boundary in the eastern Gulf of Alaska: $823-B$, P. B128-B 130 .

Rau, W.W., 1979, Unusually well preserved and diverse Eocene foraminifers in dredge samples from the eastern Gulf of Alaska continental slope: 804-B, p. B139-B141. 1981 , Unusually diverse and well preserved Eocene foraminifers in dredge samples from the eastern Gulf of Alaska continental slope: 823-B, B131-B134.

Rearic, D.M., 1985, Character and implications of new ice gouges in eastern Harrison Bay, Beaufort Sea: 945 , p. 99-110.

Reed, K.M., and Blome, C.D., 1986, Use of radiolarian biostratigraphy in stratigraphic problems in the Otuk Formation: 978, p. 16-19.

Reed, K.M., Blome, C.D., Gilbert, W.G., and Solie, D.N., 1985, Jurassic Radiolaria from the Lime Hills quadrangle: 945 , p. 53-54.

Repenning, C.A., 1978, Fossil reconnaissance study, eastern NPRA: 772-B, p. B27.

Reimnitz, Erk, and Kempema, E.W., 1987, Thirty-four-year shoreface evolution at a rapidly retreating arctic coastal site: 998, p. 161-164.

Reiser, H.N., Brosge, W.P., Dutro, J.T., Jr., and Detterman, R.L., 1979, Upper Paleozoic volcanic rocks in the eastern and central Brooks Range: 804-B, p. B25-B27.

Repetski, J.E., Carter, Claire, Harris, A.G., and Dutro, J.T., Jr., 1987, Ordovician and Silurian fossils from the Doonerak anticlinorium, central Brooks Range, Alaska: 998 , p. 40-42.

Richard, J.K., 1978, Application of remotely sensed data for ground-water analysis near Denali, Alaska: 772-B, p. B78-B79. (Report prepared under contract)

Richter, D.H., Smith, J.G., Ratte, J.C., and Leeman, W.P., 1984, Shield volcanoes in the Wrangell Mountains: 939, p. 71-75.

Riehle, J.R., and Brew, D.A., 1984, Explosive latest Pleistocene(?) and Holocene activity of the Mount Edgecumbe volcanic field, Alaska: 939, p. 111-115.

Riehle, J.R., Meyer, C.E., Ager, T.A., Kaufman, D.S., and Ackerman, R.E., 1987, The Aniakchak tephra deposit, a late Holocene marker horizon in western Alaska: 998, p.19-22. 
Rohde, W.G., Miller, W.A., and Nelson, C.A., 1978, Classification of vegetation in the Denali, Alaska area with digital Landsat data: 772-B, p. B80-B81. (Report prepared under contract)

Rosenblum, Sam, and Mosier, E.L., 1982, Europium-rich dark monazite in Alaska: 844, p. $9-11$.

Saleeby, J.B., Gehrels, G.E., Eberlein, G.D., and Berg, H.C., 1984, Progress in lead/uranium zircon studies of lower Paleozoic rocks of the southern Alexander terrane: 868 , p. 110-113.

Sanders, R.B., 1976, Summary of geology and coal resources of the Bering River Coal Field: 733 , p. 54 .

Savage, N.M., Eberlein, G.D., and Churkin, Michael, Jr., 1977, Early Devonian conodonts found with a classical Upper Silurian brachiopod fauna, southeastern Alaska: 751-B, P. B79-B80.

Schmidt, J.M., and Folger, P.F., 1986, Pb-Zn-Ag mineralization in Paleozoic dolostones, Powdermilk prospect, Baird Mountains B-4 quadrangle: 978, p. 19-21.

Schmidt, J.M., and Folger, P.F., 1987, Organic carbon occurrence and content in carbonate rocks from the Omar copper prospect, Baird Mountains, Alaska: 998, p. 43-46.

Schmoll, H.R., 1977, Engineering geology of Anchorage Borough: 751-B, P. B51-B52.

Schmoll, H.R., and Yehle, L.A., 1978, Generalized physiography and geology of the Beluga coal field and vicinity, south-central Alaska: 772-B, P. B73-B76.

Scully, D.R., 1976, Hydrologic investigations related to coal resources: 733, p. 45.

Severson, R.C., and Gough, L.P., 1984, Estimated physiological tolerance ranges for selected elements in soils, Capps coal field: 939, p. 75-78.

Sheehan, C.A., 1978, Computer enhancement of Landsat digital data for mapping material-related geomorphic features near Denali, Alaska: 772-B, p. B79-B80. (Report prepared under contract)

Shew, Nora, and Wilson, F.H., 1982, Radiometric age file for Alaska: 844, p. 12-13. Silberling, N.J., Richter, D.H., and Jones, D.L., 1981, Recognition of the Wrangellia terrane in the Clearwater Mountains and vicinity, south-central Alaska: 823-B, p. B51-B55.

Silberling, N.J., Wardlaw, B.R., and Berg, H.C., 1982, New paleontologic age determinations from the Taku terrane, Ketchikan area, southeastern Alaska: 844, p. $117-119$.

Silberman, M.L., Brookins, D.G., Nelson, S.W., and Grybeck, Donald, 1979, Rubidiumstrontium and potassium-argon dating of emplacement and metamorphism of the Arrigetch Peaks and Mount Igikpak plutons, Survey Pass quadrangle, Alaska: 804-B, P. B18-B19.

Silberman, M.L., Csejtey, Bella, Jr., Smith, J.G., Lanphere, M.A., and Wilson, F.H., 1978, New potassium-argon data on the age of mineralization and metamorphism in the Willow Creek mining district, southern Talkeetna Mountains, Alaska: 772-B, p. B65-B69.

Silberman, M.L., and Grantz, Arthur, 1984, Paleogene volcanic rocks of the Matanuska Valley area and the displacement history of the Castle Mountain fault: 868, p. 82-86.

Silberman, M.L., Mathews, Alan, Potter, R.W., and Nissenbaum, Arie, 1977, Stable isotope geochemistry, sulfide mineralogy, and potassium-argon ages of the Kennecott massive sulfide deposits, Alaska: 751-B, p. B56-B58.

Silberman, M.L., Mackevett, E.M., Jr., Connor, C.L., Klock, P.R., and Kalechitz, Georgiana, 1981 , K-Ar ages of the Nikolai Greenstone from the McCarthy quadrangle, Alaska--The "docking" of Wrangellia: 823-B, p. B61-B63.

Silberman, M.L., Mitchell, P.A., and O'Neil, J.R., 1981, Isotopic data bearing on the origin and age of the epithermal lode gold deposits in the Hope-Sunrise district, northern Kenai Peninsula, Alaska: 823-B, p. B81-B84. 
Silberman, M.L., Moll, E.J., Chapman, R.M., Patton, W.W., Jr., and Connor, C.L., 1979, Potassium-argon age of granitic and volcanic rocks from the Ruby, Medfra, and adjacent quadrangles, west-central Alaska: 804-B, p. B63-B66.

Silberman, M.L., Moll, E.J., Patton, W.W., Jr., Chapman, R.M., and Connor, C.L., 1979, Precambrian age of metamorphic rocks from the Ruby province, Medfra and Ruby quadrangles--Preliminary evidence from radiometric data: 804-B, p. B66-B68.

Silberman, M.L., Morton, J.L., Cox, D.C., and Richter, D.H., 1977, Potassium-argon ages of disseminated copper and molybdenum mineralization in the $\mathrm{Klein} \mathrm{Creek}$ and Nabesna plutons, eastern Alaska Range: 751-B, P. B54-B56.

Silberman, M.L., and O'Leary, R.M., 1976, Geochemical anomalies in the Willow Creek mining district, Talkeetna Mountains: 733, p. 48-49.

Silberman, M.L., O'Leary, R.M., Gray, L.B., and Patton, W.W., Jr., 1984, Trace-metal anomalies associated with silicification and argillic alteration in a rhyolite flow-dome complex in volcanic rocks of the Nowitna River area, Medfra quadrangle, Alaska: 868, p. 32-34.

Silberman, M.L., Potter, R.W., II, and Nissenbaum, Arie, 1976, Stable isotope, sulfide mineralogy, fluid inclusion, and $K-A r$ age study of the massive sulfide deposits at Kennecott: 733, p. 51-52.

Simpson, G.L., Vallier, T.L., PearI, J.E., and Lee-Wong, Florence, 1979, Potassiumargon ages and geochemistry of basalt dredged near Saint George Island, southern Bering Sea: 804-B, p. B134-B135.

Sims, J.D., and Rymer, M.J., 1977, Study of modern lacustrine and glaciolacustrine sediments for earthquake-induced deformational structures, Kenai Peninsula: $751-B$, P. B46-B47.

Sloan, C.E., 1976, Investigations of impact on hydrologic features by construction and operation of TAPS: 733 , p. 8-9.

1976, Arctic hydrology studies: 733, p. 23.

1976, Water-resources investigations of the Valdez-Delta Junction area: 733, p. 47.

1977, Arctic hydrology studies: 751-B, P. B30-B31.

Sloan, C.E., and Nauman, J.W., 1977, Investigations of impacts on hydrologic features by construction and operation of TAPS: 751-B, P. B6.

Sloan, C.E., and Snyder, R.F., 1978, Hydrologic reconnaissance of lakes in NPRA, 1977: 772-B, P. B28-B29.

Sloan, C.E., Trabant, Dennis, and Glude, William, 1978, Reconnaissance snow survey of NPRA, April 1977: 772-B, p. B28.

Sloan, E.G., Shearer, G.B., Easton, James, and Almquist, Carl, 1978, Preliminary investigations of coal outcrops near Farewell, Alaska: 772-B, P. B50.

Smith, Peggy, 1985, Late Quaternary geology of the Beaufort Sea inner shelf near Prudhoe Bay: 945, P. 100-103.

Sohn, I.G., 1984, Tethyan marine Triassic ostracodes in northeastern Alaska: 939, p. 21-23.

Sonnevil, R.A., 1981, The Chilkat-Prince of Wales plutonic province, southeastern Alaska: $823-B$, P. B112-B115. 1981, New data concerning the geology of the North Bradfield River iron prospects, southeastern Alaska: 823-B, P. B117-B 118 .

Spicer, R.A., and Parrish, J.T., 1987, Plant megafossils, vertebrate remains, and paleoclimate of the Kogosukruk Tongue (Late Cretaceous), North Slope, Alaska: 998 , p. 47-48.

Staatz, M.H., 1977, I and $L$ vein system, Bokan Mountain, Prince of Wales Island: 751-B, P. B 74-B 75 .

Statz, M.H., and Miller, T.P., 1976, Uranium and thorium content of radioactive phases of the Zane Hills pluton: 733 , p. 39-41. 
Stanley, R.G., 1987, Effects of weathering on petroleum-source evaluation of coals from the Suntrana Formation near Healy, Alaska: 998, p. 99-103.

Stanley, R.G., 1987, Thermal maturity and petroleum-source potential of the Cantwell Formation (Paleocene), Alaska Range: 998, p. 104-107.

Stanley, W.D., 1986, Magnetotelluric study of a compressed flysch in the Healy and adjacent quadrangles: 978 , p. 78-81.

Steele, W.C., LeCompte, J.R., and Albert, N.R.D., 1979, Landsat color mosaic of southeastern Alaska: 804-B, p. B3. 1979, Landsat data interpretation for various AMRAP quadrangles: 804-B, P. B3-B4.

Stephens, Christopher, 1978, Seismicity near Icy Bay, Alaska, and in the eastern Gulf of Alaska: 772-B, P. B96-B97.

Stephens, C.D., Fogleman, K.A., Lahr, J.C., and Page, R.A., 1985, Seismicity in southern Alaska, October 1983-September 1984: 967, p. 79-82. 1986, Seismicity in southern Alaska, October 1984-September 1985: 978 , p. 81-85.

Stephens, C.D., Fogleman, K.A., Page, R.A., and Lahr, J.C., 1985, Seismicity in southern Alaska, October 1982-September 1983: 945, p. 83-86.

Stephens, C.D., and Lahr, J.C., 1982, Seismic studies in southern and southeastern Alaska: 844 , p. 89-93. 1979, Seismicity in southern and southeastern Alaska: 804-B, p. B104-B106.

Stephens, C.D., Lahr, J.C., and Page, R.A., 1984, Seismic studies in southern Alaska: 868 , p. 7-9. 1984, Seismicity along southern coastal Alaska--October 1981-September 1982: 939, p. 78-82.

Stowel1, Harold, 1985, Sphalerite geobarometry in the Coast Range megalineament zone near Holkham Bay: 945, p. 96-99.

Tailleur, I.L., and Brosge, W.P., 1976, Need to revise and test estimates of northern Alaska coal resources: 733 , p. 26-27.

Tailleur, I.L., Ellersieck, I.F., and Mayfield, C.F., 1977, Southwestern Brooks Range-Ambler River quadrangle AMRAP: 751-B, P. B22-B24. 1977, Mineral resources of the western Brooks Range: 751-B, p. B24-B25.

Tailleur, I.L., Mayfield, C.F., and Ellersieck, I.F., 1977, Late Paleozoic sedimentary sequence, southwestern Brooks Range: 751-B, p. B25-B27.

Tailleur, I.L., Pessel, G.H., Brosge, W.P., and Mayfield, C.F., 1976, Informal cooperation between U.S. Geological Survey and State of Alaska, Division of Geological and Geophysical Surveys in the Brooks Range: 733, p. 27-30.

Tailleur, M.E., comp., 1976, Reports on Alaska published by members of the U.S. Geological Survey in late 1974 and 1975: 733, p. 65-72.

Thenhaus, P.C., Ziony, J.I., Diment, W.H., Hopper, M.G., Perkins, D.M., Hanson, S.L., and Algermissen, S.T., 1982, Probabalistic estimates of maximum seismic horizontal ground motion on rock in Alaska and the adjacent outer continental shelf: 844, p. 5-9.

Thor, D.R., and Nelson, Hans, 1978, Environmental geologic studies in the northern Bering Sea: 772-B, P. B94-B95. 1981, Environmental geologic studies of the northern Bering Sea: 823-B, p. B121-B122.

Throckmorton, M.L., and Hummel, C.L., 1979, Quartzofeldspathic, mafic, and ultramafic granulites identified in the Kigluaik Mountains, Seward Peninsula, Alaska: 804-B, p. B70-B72.

Toimi1, L.J., and Grantz, Arthur, 1976, Seabed morphology adjacent to an "island" of grounded ice in the Arctic Ocean northwest of Point Barrow: 733, p. 16-17.

Trabant, D.C., 1976, Alaska glaciology studies: 733, p. 45-47. 1976, Glaciers along TAPS route: 733 , P. 47. 
Tripp, R.B., Detra, D.E., and Nishi, J.M., 1982, Mineralized zones in bedrock near Miller Creek, Circle quadrangle: 844, p. 62-63.

Tysdal, R.G., and Case, J.E., 1977, Placer River fault, Seward and Blying Sound quadrangles: $751-B$, P. B47-B48.

1977, The McHugh Complex in the Seward quadrangle, south-central Alaska: 751-B, p. B48-B49.

Vallier, T.L., and Herman, B.M., 1987, Petrology, age, and orignal tectonic setting of basalt from the St. George Basin COST No. 1 Well, southern Bering Sea: 998, P. 165-169.

Wardlaw, B.R., 1982, Smithian and Spathian (Early Triassic) conodont faunas from the Chulitna terrane, south-central Alaska: 844, p. 106-107.

Watterson, J.R., Nishi, J.M., and Botinelly, Theodore, 1985, Evidence that gold crystals can nucleate on bacterial spores: $945, \mathrm{p} \cdot 1-4,5$.

Weber, F.R, 1982, Two new tephra localities in the Yukon-Tanana Upland: 844, P. 61-62.

1985, Late Quaternary glaciation of the Pavlof Bay and Port Moller areas, Alaska Peninsula: 967 , p. 42-44.

Weber, F.R., and Ager, T.A., 1984, Glacial-lake deposits in the Mount Harper area, Yukon-T anana Upland: 868 , p. 68-70.

Weber, F.R., and Foster, H.L., 1982, Tertiary(?) conglomerate and Quaternary faulting in the Circle quadrangle, Alaska: 844 , p. 58-61.

Weber, F.R., Foster, H.L., and Keith, T.E.C., 1977, A newly identified sequence of rocks in the Yukon-Tanana Upland, Alaska: 751-B, p. B31-B 32 .

Weber, F.R., and Turner, D.L., 1977, A late Tertiary thrust fault in the central Alaska Range: 751-B, p. B66-B67.

Webster, J.H., 1984, Preliminary report on a large granitic body in the Coast Mountains, northeast Petersburg quadrangle, southeastern Alaska: 939, p. 116-118.

Wheeler, K.L., Forbes, R.B., Weber, F.R., and Rinehart, C.D., 1987, Lithostratigraphy, petrology, and geochemistry of the Ordovician Fossil Creek Volcanics, White Mountains, east-central Alaska: 998, p. 70-73.

White, E.R., comp., 1982, Reports on Alaska published by U.S. Geological Survey authors in outside publications, 1980: 844, p. 166-173. comp., 1984, Reports on Alaska published by U.S. Geological Survey authors in outside publications, 1981: 868, p. 154-157. comp., 1984, Reports on Alaska published by the U.S. Geological Survey in 1982: 939 , p. 133-144. comp., 1984, Reports about Alaska by U.S. Geological Survey authors in nonSurvey publications in 1982 : 939, p. 145-149. comp., 1987, Reports about Alaska in USGS publications released in 1986: 998, p. $172-180$.

comp., 1987, Reports about Alaska in non-USGS publications released in 1986 which include USGS authors: 998, p. 181-186.

White, E.R., Galloway, J.P., and Booth, S.E., comps., 1986, Reports about Alaska in USGS publications released in 1985: 978, p. 146-159. comps., 1986, Reports about Alaska in non-USGS publications released in 1985 that include USGS authors: 978, p. 160-168.

Whitney, J.W., and Thurston, D.K., 1981, Geologic constraints for petroleum development of the lower Cook Inlet, Alaska, Outer Continental Shelf lease area: $823-B$, P. B122-B 124 .

Wilcox, D.E., 1979, Geohydrology of the Delta-Clearwater area: 804-B, P. B59. Williams, J.R., 1979, Stratigraphy of the Gubik Formation at Skull Cliff, northern Alaska: $804-B$, P. B31-B33. 
1986, New radiocarbon dates from the Matanuska Glacier bog section: 978 , p. 85-88.

Williams, J.R., Carter, L.D., and Yeend, W.E., 1978, Coastal plain deposits of NPRA: $772-B$, P. B20-B22.

Williams, J.R., and Coulter, H.W., 1981, Deglaciation and sea-level fluctuations in Port Valdez, Alaska: 823-B, P. B78-B80.

Williams, J.R., and Johnson, K.M., 1981, Surficial deposits of the Valdez quadrangle, Alaska: 823-B, P. B76-B78.

Williams, J.R., and Yeend, W.E., 1979, Deep thaw lake basins of the inner Arctic Coastal Plain, Alaska: 804-B, P. B35-B37.

Wilson, F.H., 1981, K-Ar ages on intrusive rocks and altered zones in the Chignik and Sutwik Island quadrangles: 823-B, P. B45-B46.

Wilson, F.H., Case, J.E., and Detterman, R.L., 1985, Preliminary description of a Miocene zone of structural complexity, Port Moller and Stepovak Bay quadrangles: 945 , p. 55-56.

Wilson, F.H., Detterman, R.L., and Silberman, M.L., 1978, New ages on intrusive rocks and altered zones on the Alaska Peninsula: 772-B, p. B63-B65.

Wilson, F.H., and Shew, Nora, 1982, Apparent episodicity of magmatic activity deduced from radiometric age determinations: 844 , p. 13-14. 1982, Preliminary results of potassium-argon age determinations from the Ugashik quadrangle, Alaska Peninsula: 844, p. 86-87.

Winkler, G.R., 1976, Reconnaissance geochemistry and tectonics of Gulf of Alaska greenstones: 733 , p. 11 .

1978, Framework grain mineralogy and provenance of sandstones from the Arkose Ridge and Chickaloon Formations, Matanuska Valley: 772-B, P. B70-B73. comp., 1986, Data releases and folio reports prepared for the Alaska Mineral Resource Assessment Program and the Regional Alaska Mineral Resource Assessment Program listed al phabetically by quadrangle: 978 , p. 110-145.

Winkler, G.R., and Grybeck, D.J., 1986, The Alaska Mineral Resource Assessment Program in 1985: 978 , P. 3-5.

Winkler, G.R., Mackevett, E.M., Jr., and Nelson, S.W., 1977, Strata-bound ironcopper-zinc sulfide deposits, Prince William Sound region, southern Alaska: $751-B$, P. B44-B45.

Winkler, G.R., Miller, R.J., and Case, J.E., 1981, Blocks and belts of blueschist and greenschist in the northwestern Valdez quadrangle: 823-B, P. B72-B74.

Winkler, G.R., Miller, R.J., Silberman, M.L., Grantz, Arthur, Case, J.E., and Pickthorn, W.J., 1981, Layered gabbroic belt of regional extent in the Valdez quadrangle: 823-B, P. B74-B76.

Winkler, G.R., and Plafker, George, 1981, Tectonic implications of framework grain mineralogy of sandstone from the Yakutat Group: 823-B, P. B68-B70.

Winkler, G.R., and Tysdal, R.G., 1977, Conglomerate in flysch of the Orca Group, Prince William Sound, southern Alaska: 751-B, p. B43-B44.

Yeend, W.E., 1978, Surficial geology of the foothills and mountains of NPRA: 772-B, P. B19-B20.

1981 , Placer gold deposits, Mount Hayes quadrangle, Alaska: 823-B, p. B68. 1982, Placers and placer mining, Circle District: 844, p. 64.

1984, Gold in Tertiary(?) rocks, Circle quadrangle, Alaska: 868, p. 65-66. 1984, Placers and placer mining in the Healy quadrangle, southern Alaska: 868, p. 95-98.

1984, Surficial geology of Lookout Ridge quadrangle: 939, p. 23-25.

1985, Trace elements of placer gold: 945, p. 4-7.

1987, Placer gold related to mafic schist(?) in the Circle District, Alaska: 998, p. 74-76. 
Yehle, L.A., 1976, Reconnaissance engineering geology and geological hazards of the Yakutat area: 733 , p. 54. 1977, Reconnaissance engineering geology and geologic hazards of the Metlakatla area, Annette Island: 751-B, P. B72.

1979, Reconnaissance engineering geology and geologic hazards of the Petersburg area, southeastern Alaska: 804-B, p. B130-B131.

York, J.E., Wilson, F.H., and Gamble, B.M., 1985, Digital image processing techniques for detecting surface alteration--An application on the Alaska Peninsula: 945 , p. 56-58.

Yount, M.E., 1976, Computer files of Alaskan data: 733, p. 1-2.

Yount, M.E., Miller, T.P., Emanuel, R.P., and Wilson, F.H., 1985, Eruption in an icefilled caldera, Mount Veniaminof, Alaska Peninsula: 945, p. 58-60.

Yount, M.E., Miller, T.P., and Gamble, B.M., 1987, The 1986 Eruptions of Augustine Volcano, Alaska--Hazards and effects: 998, p. 4-13.

Yount, M.E., Wilson, F.H., and Miller, J.W., 1985, Newly discovered Holocene volcanic vents, Port Moller and Stepovak Bay quadrangles: 945, p. 60-62.

Zayatz, M.R., 1987, Petrography of the Baird Mountains schistose lithologies, northwestern Alaska: 998, p. 49-52.

Zen, E-An, and Hammarstrom, J.M., 1984, Mineralogy and a petrogenetic model for the tonalite pluton at Bushy Point, Revillagigedo Island, Ketchikan $1^{\circ} \times 2^{\circ}$ quadrangle, southeastern Alaska: 939, p. 118-123.

Zenone, Chester, 1976, Geohydrology of the Anchorage area: 733, p. 52-53. 1977, Urban hydrology studies in the Anchorage area: 751-B, p. B52. 1978, Water resources studies in the Anchorage area: 772-B, p. B81-B82.

Zenone, Chester, and Anderson, G.S., 1978, Regional appraisal of Alaska's groundwater resources: $772-B, P . B 7$.

Zimmerman, Jay, and Frank, C.0., 1982, Possible obduction-related metamorphic rocks at the base of the ultramafic zone, Avan Hills complex, De Long Mountains: 844, p. 27-28.

Zimmerman, Jay, Frank, C.0., and Bryn, Sean, 1981, Mafic rocks in the Avan Hills ultramafic complex, De Long Mountains: 823-B, p. B14-B15.

Zimmerman, Jay, and Soustek, P.G., 1979, The Avan Hills ul tramafic complex, De Long Mountains, Alaska: 804-B, p. B8-B11. 


\section{ARTICLES ARRANGED REGIONALLY, THEN BY SUBJECT MATTER}

\section{Statewide}

\section{Compilations; bibliographies}

Anonymous, 1977, Reports on Alaska published by the U.S. Geological Survey, 1976: 751-B, P. B104-B112.

--1978 , Reports on Alaska published by the U.S. Geological Survey in 1977: 772-B, p. B102-B110.

Cobb, E.H., comp., 1979, Reports on Alaska published by the U.S. Geological Survey in 1978: 804-B, P. B 147-B158. comp., 1981, Reports on Alaska published by the U.S. Geological Survey in 1979: 823-B, p. B138-B145.

comp., 1982, Reports on Alaska published by the U.S. Geological Survey in 1980: 844, p. 154-165. comp., 1984, Reports on Alaska published by the U.S. Geological Survey in 1981: 868, p. 141-153.

Tailleur, M.E., comp., 1976, Reports on Alaska published by members of the U.S. Geological Survey in late 1974 and 1975: 733, p. 65-72.

White, E.R., comp., 1979, Reports on Alaska published by U.S. Geological Survey authors in outside publications in 1978: 804-B, P. B158-B161. comp., 1981, Reports on Alaska published by U.S. Geological Survey authors in outside publications in 1979: 823-B, p. B146-B149. comp., 1982, Reports on Alaska published by U.S. Geological Survey authors in outside publications, 1980: 844, p. 166-173. comp., 1984, Reports on Alaska published by U.S. Geological Survey authors in outside publications in 1981: 868, p. 154-157. comp., 1984, Reports on Alaska published by the U.S. Geological Survey in 1982: 939 , p. 133-144. comp., 1984, Reports about Alaska by U.S. Geological Survey authors in nonSurvey publications in 1982; 939, p. 145-149. comp., 1987, Reports about Alaska in USGS publications released in 1986: 998, p. $172-180$. comp., 1987, Reports about Alaska in non-USGS publications released in 1986 which include USGS authors: 998, p. 181-186.

White, E.R., Galloway, J.P., and Booth, S.E., comps., 1986, Reports about Alaska in USGS publications released in 1985: 978, p. 146-159. comps., 1986, Reports about Alaska in non-USGS publications released in 1985 that include USGS authors: 978 , p. 160-168.

Winkler, G.R., comp., 1986, Data releases and folio reports prepared for the Alaska Mineral Resource Assessment Program and the Regional Alaska Mineral Resource Assessment Program listed alphabetically by quadrangle: 978, p. 110-145.

Yount, M.E., 1976, Computer files of Alaskan data: 733, p. 1-2.

\section{Economic geology}

Cobb, E.H., 1976, Mineral resources of Alaska: 733, p. 2. 1977, Mineral resources of Alaska: 751-B, P. B1-B4. 1978, Mineral resources of Alaska: 772-B, p. B1. 1979, Mineral resources of Alaska: 804-B, p. Bl.

Leonard, K.R., and Huber, D.F., 1987, Status of Alaska Mineral Resources Data System: $998, \mathrm{p} \cdot 15-18$. 
Rosenblum, Sam, and Mosier, E.L., 1982, Europium-rich dark monazite in Alaska: 844, p. 9-11.

Watterson, J.R., Nishi, J.M., and Botinelly, Theodore, 1985, Evidence that gold crystals can nucleate on bacterial spores: 945, p. 1-4, 5 .

Winkler, G.R., and Grybeck, D.J., 1986, The Alaska Mineral Resource Assessment Program in 1985: 978, p. 3-5.

Yeend, Warren, 1985, Trace elements of placer gold: 945, p. 4-7.

\section{General geology}

Albert, N.R.D., Steele, W.C., and LeCompte, J.R., 1978, Landsat color mosaic of Alaska: 772-B, P. B1-B4. 1978, Landsat data interpretation of various AMRAP quagrangles, Alaska: 772-B, P. B4-B5.

Barnes, D.F., and Plouff, Donald, 1984, Computer-generated latitude and longitude templates for rapid determination of geographic positions in Alaska: 868, p. 10-11.

Beikman, H.M., 1977, Preliminary geologic map of Alaska: 751-B, P. B1.

Wilson, F.H., and Shew, Nora, 1982, Apparent episodicity of magmatic activity deduced from radiometric age determinations: 844 , p. 13-14.

Winkler, G.R., and Grybeck, D.J., 1986, The Alaska Mineral Resource Assessment Program in 1985: 978, p. 3-5.

\section{Geochemistry}

Curtin, G.C., Crim, W.D., King, H.D., Cooley, E.F., Forn, C.L., Hoffman, J.D., O'Leary, R.M., and Tripp, R.B., 1979, Reconnaissance geochemical studies in Alaska: $804-B$, p. B4-B5.

Curtin, G.C., Day, G.W., Forn, C.L., Hessin, T.D., Hoffman, J.D., Marsh, S.P., O'Leary, R.M., and Tripp, R.B., 1976, Exploration geochemistry in Alaska: 733, p. 5-7.

Curtin, G.C., Hessin, T.D., O'Leary, R.M., Cooley, E.F., Day, G.W., and Tripp, R.B., 1978, Geochemical exploration studies in Alaska: 772-B, P. B5-B6.

O'Leary, R.M., and Hoffman, J.D., 1984, Alaskan geochemical field laboratories: 868, p. 10 .

O'Leary, R.M., and McDanal, S.K., 1982, Alaskan geochemical field laboratories: 844, P. $11-12$.

Watterson, J.R., Nishi, J.M., and Botinelly, Theodore, 1985, Evidence that gold crystals can nucleate on bacterial spores: $945, \mathrm{p} .1-4,5$.

Yeend, Warren, 1985, Trace elements of placer gold: 945, p. 4-7.

\section{Geochronology}

Shew, Nora, and Wilson, F.H., 1982, Radiometric age file for Alaska: 844, p. 12-13. Wilson, F.H., and Shew, Nora, 1982, Apparent episodicity of magmatic activity deduced from radiometric age determinations: 844, p. 13-14.

\section{Geophysics}

Barnes, D.F., 1976, New gravity map of Alaska: 733, p. 2-5. 1984, Digital elevation models improve processing of Alaskan gravity data: 868, p. 5-7. 


\section{Geothermal studies}

Lachenbruch, A.H., Sass, J.H., Marshall, B.V., Moses, T.H., Jr., Munroe, R.J., and Smith, E.P., 1984, Geothermal studies in Alaska--Conditions at Prudhoe Bay: 868 , p. $19-20$.

Lawver, L.A., Lachenbruch, A.H., and Moses, T.H., Jr., 1979, Status of regional heatflow studies in Alaska: 804-B, p. B5-B7.

\section{Hydrology}

Childers, J.M., 1976, Streamflow, channel erosion, and icings along TAPS route: 733, p. 8.

Childers, J.M., Kernodle, D., and Loeffler, R., 1978, Stream flow and channel erosion investigations along the TAPS route: $772-B, P . B 6-B 7$.

Doyle, P.F., 1977, Streamflow and channel erosion along the TAPS route: $751-B$, P. B7.

Jones, S.H., 1976, Hydrologic reconnaissance of TAPS haulroad: 733, p. 9.

Madison, R.J., 1976, Alaskan quality-of-water station network (NASQAN): 733, p. 7. 1976, Hydrological studies for the Alaskan Air Command: 733, p. 30.

Mayo, L.R., 1977, Glacier research: 751-B, P. B5-B6.

McCoy, G.A., 1977, Fisheries enhancement studies--Limnological studies in southeastern Alaska and water quality measurements along the TAPS route during pipeline construction: 751-B, P. B7-B8.

Nauman, J.W., and Kernodle, D.R., 1976, Water quality and benthic invertebrates along the TAPS route: 733 , p. 8 .

Nauman, J.W., Sloan, C.E., and Kernodle, D.R., 1977, Effects of fuel oil leaks on water quality in three streams along the trans-Alaska pipeline: 751-B, P. B7.

Post, Austin, and Meier, M.F., 1979, Glacier inventories: 804-B, P. B7.

Sloan, C.E., 1976, Investigations of impact on hydrologic features by construction and operation of TAPS: 733 , p. 8-9.

Sloan, C.E., and Nauman, J.W., 1977, Investigations of impacts on hydrologic features by construction and operation of TAPS: 751-B, P. B6.

Zenone, Chester, and Anderson, G.S., 1978, Regional appraisal of Alaska's groundwater resources: $772-B, P . B 7$.

\section{Marine geology}

Thenhaus, P.C., Ziony, J.I., Diment, W.H., Hopper, M.G., Perkins, D.M., Hanson, S.L., and Algermissen, S.T., 1982, Probabalistic estimates of maximum seismic horizontal ground motion on rock in Alaska and the adjacent outer continental shelf: 844, p. 5-9.

\section{Miscellaneous}

Behrendt, E.C., 1984, The U.S. Geological Survey Public Inquiries office in Anchorage: 868 , p. 11-12.

\section{Oil and gas}

Nauman, J.W., Sloan, C.E., and Kernodle, D.R., 1977, Effects of fuel oil leaks on water quality in three streams along the trans-Alaska pipeline: 751-B, P. B7. 


\section{Paleontology}

Churkin, Michael, Jr., Carter, Claire, and Johnson, B.R., 1977, A new Ordovician time scale based on accumulation rates of graptolitic shale: 751-B, B4-B5.

\section{Petrology; petrography}

Rosenblum, Sam, and Mosier, E.L., 1982, Europium-rich dark monazite in Alaska: 844, p. 9-11.

\section{Quaternary geology}

Mayo, L.R., 1977, G1acier research: 751-B, p. B5-B6.

Post, Austin, and Meier, M.F., 1979, Glacier inventories: 804-B, P. B7.

Riehle, J.R., Meyer, C.E., Ager, T.A., Kaufman, D.S., and Ackerman, R.E., 1987, The Aniakchak tephra deposit, a late Holocene marker horizon in western Alaska: 998, p.19-22.

\section{Remote sensing}

Albert, N.R.D., Steele, W.C., and LeCompte, J.R., 1978, Landsat color mosaic of Alaska: 772-B, P. B1-B4. 1978, Landsat data interpretation of various AMRAP quadrangles, Alaska: 772-B, P. B4-B5.

LeCompte, J.R., Steele, W.C., and Albert, N.R.D., 1984, Sumary of Landsat quadrangle studies in Alaska: $868, \mathrm{p} .1-4$.

Steele, W.C., LeCompte, J.R., and Albert, N.R.D., 1979, Landsat data interpretation for various AMRAP quadrangles: $804-B$, P. B3-B4.

\section{Sedimentary geology}

Churkin, Michael, Jr., Carter, Claire, and Johnson, B.R., 1977, A new Ordovician time scale based on accumulation rates of graptolitic shale: 751-B, B4-B5.

Riehle, J.R., Meyer, C.E., Ager, T.A., Kaufman, D.S., and Ackerman, R.E., 1987, The Aniakchak tephra deposit, a late Holocene marker horizon in western Alaska: 998, p. 19-22.

\section{Seismicity}

Thenhaus, P.C., Ziony, J.I., Diment, W.H., Hopper, M.G., Perkins, D.M., Hanson, S.L., and Algermissen, S.T., 1982, Probabalistic estimates of maximum seismic horizontal ground motion on rock in Alaska and the adjacent outer continental shelf: 844 , p. 5-9.

\section{Structural geology; tectonics}

Jones, D.L., Silberling, N.J., Berg, H.C., and Plafker, George, 1982, Tectonostratigraphic terrane map of Alaska: 844, p. $1-5$.

\section{Volcanoes; volcanic rocks}

Riehle, J.R., Meyer, C.E., Ager, T.A., Kaufman, D.S., and Ackerman, R.E., 1987, The Aniakchak tephra deposit, a late Holocene marker horizon in western Alaska: 998, p.19-22. 


\section{Northern Alaska}

\section{Coa1}

Callahan, J.E., 1976, Northern Alaska coal investigations, western Naval Petroleum Reserve No. 4: 733, p. 30 .

Tailleur, I.L., and Brosge, W.P., 1976, Need to revise and test estimates of northern Alaska coal resources: 733 , p. 26-27.

\section{Economic geology}

Armstrong, A.K., 1982, Petrography and cathode luminescence of carbonate rocks at Bornite, Alaska: 844 , p. $38-40$.

Barnes, D.F., and Morin, R.L., 1984, Gravity measurements show large size of Red Dog zinc-lead-barite prospect in northwestern Alaska: 939, p. 1-5.

Brosge, W.P., and Reiser, H.N., 1977, Lead-zinc mineralization at Bear Mountain, southeastern Brooks Range: $751-B$, P. B8-B 10 .

Cathrall, J.B., 1982, Evidence from stream-sediment geochemical and biogeochemical data, mineral occurrences, and Landsat images for potential mineralized targets in the Brooks Range, Alaska: 844 , p. 41. 1982, Potential mineralized target areas in the Brooks Range schist belt are characterized by anomalous stream-sediment geochemistry, magnetic, and 1ithologic signature: 844 , p. 40-41.

Churkin, Michael, Jr., Huie, Carl, Mayfield, C.F., and Nokleberg, W.J., 1978, Geologic investigations of metallic mineral resources of southern NPRA: 772-B, p. B15-B17.

Dutro, J.T., Jr., 1978, Potential strata-bound lead-zinc mineralization, Philip Smith Mountains quadrangle, Alaska: 772-B, p. B9-B11.

Duttweiler, K.A., 1986, Sulfide occurrences in the Itkillik River region, southeast Chandler Lake quadrangle, Brooks Range: 978 , p. 10-13.

1987, Use of factor analysis in locating base metal mineralization in the Killik River quadrangle, Alaska: 998, p. 27-30.

Ellersieck, Inyo, Blanchard, D.C., Curtis, S.M., Mayfield, C.F., and Tailleur, I.L., 1984, Kivivik Creek--A possible zinc-lead-silver occurrence in the Kuna Formation, western Baird Mountains, Alaska: $868, \mathrm{p} .16-17$.

Ellersieck, I.F., Jansons, Uldis, Mayfield, C.F., and Tailleur, I.I., 1982, The Story Creek and Whoopee Creek lead-zinc-silver occurrences, western Brooks Range, Alaska: 844, p. 35-38.

Folger, P.F., Goldfarb, R.J., Bailey, E.A., O'Leary, R.M., and Sutley, S.J., 1985, Use of stream-sediment insoluble residues in geochemical exploration for carbonate-hosted mineral deposits in the Baird Mountains: 967, p. 5-8.

Folger, P.F., Goldfarb, R.J., and Schmidt, J.M., 1987, Preliminary evaluation of geochemical anomalies in the Baird Mountains quadrangle, Alaska: 998, p. $31-34$.

Grybeck, Donald, and Nokleberg, W.J., 1979, Metallogeny of the Brooks Range, Al aska: $804-B$, P. B19-B22.

Huffman, A.C., Kirk, A.R., and Molenaar, C.M., 1982, Uranium investigations-Northeastern Alaska: 844 , p. 41-43.

Mayfield, C.F., Curtis, S.M., Ellersieck, I.F., and Tailleur, I.L., 1979, The Ginny Creek zinc-lead-silver and Nimiuktuk barite deposits, northwestern Brooks Range, Alaska: 804-B, P. B $11-B 12$.

Nokleberg, W.J., and Winkler, G.R., 1978, Stratiform zinc-lead mineralization, Drenchwater Creek area, Howard Pass quadrangle, western Brooks Range, Alaska: $772-\mathrm{B}$, P. B17-B 19 . 
Schmidt, J.M., and Folger, P.F., 1986, Pb-Zn-Ag mineralization in Paleozoic dolostones, Powdermilk prospect, Baird Mountains B-4 quadrangle: 978, p. 19-21. 1987, Organic carbon occurrence and content in carbonate rocks from the Omar copper prospect, Baird Mountains, Alaska: 998, p. 43-46.

Tailleur, I.L., Ellersieck, I.F., and Mayfield, C.F., 1977, Mineral resources of the western Brooks Range: 751-B, p. B24-B25. 1977, Southwestern Brooks Range-Ambler River quadrangle AMRAP: 751-B, p. B22-B24.

\section{General geology}

Carter, L.D., Marincovich, Louie, Jr., Brouwers, E.M., and Forester, R.M., 1979, Paleogeography of a Pleistocene coastline, Alaskan Arctic Coastal Plain: 804-B, p. B39-B41.

Detterman, R.L., and Spicer, R.A., 1981, New stratigraphic assignment for rocks along Igilatvik (Sabbath) Creek, William 0. Douglas Arctic Wildlife Range, Alaska: $823-B$, P. B11-B12.

Ellersieck, Inyo, Tailleur, I.L., Mayfield, C.F., and Curtis, S.M., 1979, A new find of Upper Cretaceous or Tertiary sedimentary rocks in the Noatak Valley: 804-B, p. B13.

Grybeck, D.J., Cathrall, J.B., LeCompte, J.R., and Cady, J.W., 1985, Buried felsic plutons in Upper Devonian redbeds, central Brooks Range: 945, p. 8-10.

Huffman, A.C., Kirk, A.R., and Molenaar, C.M., 1982, Uranium investigations-Northeastern Alaska: 844 , p. 41-43.

LeCompte, J.R., and Steele, W.C., 1981, Landsat data interpretation in the southcentral Brooks Range and in southeastern Alaska: 823-B, P. B1-B3.

Tailleur, I.L., Ellersieck, I.F., and Mayfield, C.F., 1977, Southwestern Brooks Range-Ambler River quadrangle AMRAP: 751-B, P. B22-B24.

Tailleur, I.L., Mayfield, C.F., and Ellersieck, I.F., 1977, Late Paleozoic sedimentary sequence, southwestern Brooks Range: 751-B, P. B25-B27.

Tailleur, I.L., Pessel, G.H., Brosge, W.P., and Mayfield, C.F., 1976, Informal cooperation between U.S. Geological Survey and State of Alaska, Division of Geological and Geophysical Surveys in the Brooks Range: 733, p. 27-30.

\section{Geochemistry}

Cathrall, J.B., 1982, Evidence from stream-sediment geochemical and biogeochemical data, mineral occurrences, and Landsat images for potential mineralized targets in the Brooks Range, Alaska: 844 , p. 41.

1982, Potential mineralized target areas in the Brooks Range schist belt are characterized by anomalous stream-sediment geochemistry, magnetic and 1 ithologic signature: 844, p. 40-41.

Collett, T.S., Kvenvolden, K.A., Magoon, L.B., and Bird, K.J., 1987, Geochemical and geologic controls on the inferred occurrence of natural gas hydrate in the Kuparuk 2D-15 well, North Slope, Alaska: 998, p. 24-26.

Duttweiler, K.A., 1987, Use of factor analysis in locating base metal mineralization in the Killik River quadrangle, Alaska: 998, p. 27-30.

Folger, P.F., Goldfarb, R.J., Bailey, E.A., O'Leary, R.M., and Sutley, S.J., 1985, Use of stream-sediment insoluble residues in geochemical exploration for carbonate-hosted mineral deposits in the Baird Mountains: 967, p. 5-8.

Folger, P.F., Goldfarb, R.J., and Schmidt, J.M., 1987, Preliminary evaluation of geochemical anomalies in the Baird Mountains quadrangle, Alaska: 998, p. 31-34. 
Karl, S.M., Schmidt, J.M., and Folger, P.F., 1985, Selected anomalous rock and sediment samples from central and northwestern Baird Mountains quadrangle: 967, p. 8-13.

Magoon, L.B., and Claypool, G.E., 1978, Organic geochemistry of rocks from three NPRA wells: 772-B, P. B25-B26.

Nokleberg, W.J., and Winkler, G.R., 1978, Stratiform zinc-lead mineralization, Drenchwater Creek area, Howard Pass quadrangle, western Brooks Range, Alaska: $772-B$, P. B17-B 19 .

\section{Geochronology}

Brigham, J.K., 1984, Marine stratigraphy and amino acid geochronology of the Gubik Formation, western Arctic Coastal Plain, Alaska: 939, p. 5-9.

Brosge, W.P., Reiser, H.N., and Dutro, J.T., Jr., 1981, Significance of Middle Devonian clastic rocks in the eastern Brooks Range, Alaska: 823-B, P. B24-B25.

Hamilton, T.D., Ashley, G.M., Reed, K.M., and Van Etten, D.P., 1984, Stratigraphy and sedimentology of Epiguruk Bluff--A preliminary account: 939, p. 12-14.

Hamilton, T.D., and Hopkins, D.M., 1982, Correlation of northern Alaska glacial deposits--A provisional stratigraphic framework: 844, p. 15-18.

Hamilton, T.D., Lancaster, G.A. and Trimble, D.A., 1987, Glacial advance of late Wisconsin (Itkillik II) age in the upper Noatak River valley--A radiocarbondated stratigraphic record: 998 , p. 35-39.

Hopkins, D.M., and Robinson, S.W., 1979, Radiocarbon dates $f$ rom the Beaufort and Chukchi Sea coasts: 804-B, p. B44-B46.

Silberman, M.L., Brookins, D.G., Nelson, S.W., and Grybeck, Donald, 1979, Rubidiumstrontium and potassium-argon dating of emplacement and metamorphism of the Arrigetch Peaks and Mount Igikpak plutons, Survey Pass quadrangle, Alaska: 804-B, P. B18-B19.

\section{Geophysics}

Barnes, D.F., 1981, Gravity measurements useful in exploration and evaluation of the Nimiuktuk barite deposit: 823-B, p. B15-B17. 1985, Gravity lows may indicate Pleistocene deposits beneath glacial Lake Noatak: 967, p. $1-5$.

Barnes, D.F., and Morin, R.L., 1984, Gravity measurements show large size of Red Dog zinc-lead-barite prospect in northwestern Alaska: 939, p. 1-5.

Boucher, Gary, 1976, Study of the gravity field of the Beaufort shelf, north coast of Alaska: 733 , p. 21-22.

Curtis, S.M., Rossiter, Richard, Ellersieck, I.F., Mayfield, C.F., and Tailleur, I.L., 1979, Gamma-ray values in the Misheguk Mountain region and in parts of Barrow, Teshekpuk, and Harrison Bay quadrangles: 804-B, p. B14.

Giovanetti, Dennis, and Bird, K.J., 1978, Geophysical profiles through the ShaviovikEchooka River region: $772-B$, P. B32-B33.

Hillhouse, J.W., and Gromme, Sherman, 1982, Cretaceous overprint revealed by paleomagnetic study in the northern Brooks Range: 844, p. 43-46.

Long, C.L., and Thompson, Bill, 1986, Audio-magnetotelluric resistivity traverses in the Baird Mountains quadrangle: 978, p. 13-16.

\section{Geothermal studies}

Blanchard, D.C., and Tailleur, I.L., 1982, Preliminary geothermal isograd map, NPRA : 844 , p. 46-48. 
Lachenbruch, A.H., and Marshall, B.V., 1978, A simple target model for offshore permafrost at Prudhoe Bay: 772-B, p. B30-B32.

\section{Bydrology}

Carter, L.D., and Galloway, J.P., 1979, Arctic Coastal Plain pingos in National Petroleum Reserve in Alaska: 804-B, P. B33-B 34 .

Childers, J.M., Arctic water resources and environmental studies: 733 , p. 9.

Childers, J.M., and Kernodle, D.R., 1979, Water resources of the Noatak River basin: 804-B, P. B53-B54. 1982, Hydrologic reconnaissance of the Kobuk River basin: 844, p. 80-81.

Childers, J.M., Kernodle, D., and Loeffler, R., 1978, Hydrology of arctic Alaska: 772-B, P. B33-B 34 .

Feulner, A.J., and Williams, J.R., 1981, Further notes on the ground-water supply beneath Selim Creek near Cape Lisburne, northwestern Alaska: 823-B, p. B12-B14.

Jones, S.H., 1978, Streamflow in NPRA, 1977: 772-B, p. B29.

McCoy, G.A., 1982, Nutrient limitation in two arctic lakes: 844, p. 53.

Meckel, J.P., 1976, Environmental data collection along proposed Canadian gas pipeline along coastal route in Alaska: 733 , p. 23.

Nelson, G.L., 1976, North Slope water resources studies: 733, p. 23. 1977, North slope water resources studies: 751-B, p. B31.

Sloan, C.E., Arctic hydrology studies: 733, p. 23.

Sloan, C.E., and Snyder, R.F., 1978, Hydrologic reconnaissance of lakes in NPRA, 1977: 772-B, P. B28-B29.

Sloan, C.E., Trabant, Dennis, and Glude, William, 1978, Reconnaissance snow survey of NPRA, April 1977: 772-B, p. B28.

\section{Marine geology}

Boucher, Gary, 1976, Study of the gravity field of the Beaufort shelf, north coast of Alaska: 733 , p. 21-22.

Brigham, J.K., 1984, Marine stratigraphy and amino acid geochronology of the Gubik Formation, western Arctic Coastal Plain, Alaska: 939, p. 5-9.

Brouwers, E.M., Marincovich, Louie, Jr., and Hopkins, D.M., 1984, Pal eoenvironmental record of Pleistocene transgressive events preserved at Skull Cliff, northern Alaska: 939, p. 9-12.

Carter, L.D., Marincovich, Louie, Jr., Brouwers, E.M., and Forester, R.M., 1979, Paleogeography of a Pleistocene coastline, Alaskan Arctic Coastal Plain: 804-B, p. B39-B41.

Carter, L.D., and Robinson, S.W., 1981, Minimum age of beach deposits north of Teshekpuk Lake, Alaskan Arctic Coastal Plain: 823-B, p. B8-B9.

Hopkins, D.M., and Robinson, S.W., 1979, Radiocarbon dates from the Beaufort and Chukchi Sea coasts: 804-B, p. B44-B46.

Lachenbruch, A.H., and Marshall, B.V., 1978, A simple target model for offshore permafrost at Prudhoe Bay: $772-B$, p. B30-B 32 .

Marincovich, Louie, Jr., Brouwers, E.M., and Carter, L.D., 1984, Early Tertiary marine fossils from Ocean Point, Arctic Coastal Plain, and their relation to Arctic Ocean paleogeography: 939, p. 15-17.

\section{Metamorphic geology}

Hillhouse, J.W., and Gromme, Sherman, 1982, Cretaceous overprint revealed by paleomagnetic study in the northern Brooks Range: 844, p. 43-46.

Mayfield, C.F., 1976, Metamorphism in the southwestern Brooks Range: 733, p. 31-32. 
Mayfield, C.F., Silberman, M.L., and Tailleur, I.L., 1982, Precambrian metamorphic rocks from the Hub Mountain terrane, Baird Mountains quadrangle, Alaska: 844, p. $18-22$.

Nelson, S.W., and Grybeck, Donald, 1979, Tectonic significance of metamorphic grade distribution, Survey Pass quadrangle, Alaska: 804-B, P. B16-B17.

Silberman, M.L., Brookins, D.G., Nelson, S.W., and Grybeck, Donald, 1979, Rubidiumstrontium and potassium-argon dating of emplacement and metamorphism of the Arrigetch Peaks and Mount Igikpak plutons, Survey Pass quadrangle, Alaska: 804-B, P. B18-B19.

Zayatz, M.R., 1987, Petrography of the Baird Mountains schistose 1 ithologies, northwestern Alaska: 998, p. 49-52.

$\mathrm{Z}$ immerman, Jay, and Frank, C.0., 1982, Possible obduction-related metamorphic rocks at the base of the ultramafic zone, Avan Hills complex, De Long Mountains: 844, p. 27-28.

\section{Oil and gas}

Bird, K.J., 1976, Petroleum potential of the Lisburne Group, eastern Arctic Slope: 733 , P. 26.

Carter, R.D., 1976, North Slope petroleum program: 733, p. 23-24. 1978, Release of NPRA (NPR-4) data: 772-B, P. B26-B27. 1981, National Petroleum Reserve in Alaska--Data release: 823-B, P. B3-B4. 1982, NPRA data release, 1980: 844, p. 48-49.

Carter, R.D., and Lantz, R.J., 1978, Development and operation of gas fields in the South Barrow area: 772-B, P. B29-B30. 1979, Development and operation of gas fields in the Barrow area: 804-B, P. B52-B53.

Carter, R.D., and Madrid, R.J., 1979, Availability of NPRA data: 804-B, P. B53. Carter, R.D., Mul1, C.G., and Bird, K.J., 1977, Any Prudhoe Bays in Naval Petroleum Reserve No. 4?: 751-B, P. B14-B15.

Collett, T.S., Kvenvolden, K.A., Magoon, L.B., and Bird, K.J., 1987, Geochemical and geologic controls on the inferred occurrence of natural gas hydrate in the Kuparuk 2D-15 well, North Slope, Alaska: 998 , p. 24-26.

Magoon, L.B., and Claypool, G.E., 1978, Organic geochemistry of rocks from three NPRA wells: 772-B, p. B25-B26.

Molenaar, C.M., Egbert, R.M., and Krystinik, L.F., 1982, Depositional facies and reservoir potential of the Fortress Mountain Formation, central North Slope: 844 , p. 32-33.

Mul1, C.G., and Kososki, B.A., 1977, Hydrocarbon assessment of the Arctic National Wildlife Refuge, eastern Arctic Slope, Alaska: 751-B, P. B20-B22.

\section{Paleontology}

Armstrong, A.K., and Mamet, B.L., 1977, Carboniferous microfacies, microfossils, and corals, Lisburne Group, arctic Alaska: 751-B, P. B18. 1977, Mississippian microfacies of the Lisburne Group, Endicott Mountains, arctic Alaska: 751-B, P. B18-B19.

Bird, K.J., 1977, Late Paleozoic carbonates from the south-central Brooks Range: 751-B, P. B19-B20.

Blodgett, R.B., Clough, J.G., Dutro, J.T., Jr., Ormiston, A.R., Palmer, A.R., and Taylor, M.E., 1986, Age revisions for the Nanook Limestone and Katakturuk Dolomite, northeastern Brooks Range: 978, p. 5-10.

Detterman, R.L., 1976, Biostratigraphy of the Permian and Lower Triassic rocks in the Philip Smith Mountains quadrangle: 733 , p. 32-33. 
Detterman, R.L., and Dutro, J.T., Jr., 1977, Depositional environment and fauna for a section of the Sadlerochit Group, northeastern Alaska: 751-B, P. B10-B12.

Hamilton, T.D., Ashley, G.M., Reed, K.M., and Van Etten, D.P., 1984, Stratigraphy and sedimentology of Epiguruk Bluff--A preliminary account: 939, p. 12-14.

Marincovich, Louie, Jr., Brouwers, E.M., and Carter, L.D., 1984, Early Tertiary marine fossils from Ocean Point, Arctic Coastal Plain, and their relation to Arctic Ocean paleogeography: 939, p. 15-17.

Morgan, A.V., Morgan, Anne, and Carter, L.D., 1979, Paleoenvironmental interpretation of a fossil insect fauna from bluffs along the lower Colville River, Alaska: 804-B, P. B41-B44.

Murchey, B.L., Swain, P.B., and Curtis, Steven, 1981, Late Mississippian to Pennsylvanian radiolarian assemblages in the Siksikpuk(?) Formation at Nigu Bluff, Howard Pass quadrangle, Alaska: 823-B, P. B17-B19.

Plafker, George, Hudson, Travis, and Jones, D.L., 1978, Upper Triassic radiolarian chert from the Kobuk volcanic sequence in the southern Brooks Range: 772- $B$, p. B45-B47.

Reed, K.M., and Blome, C.D., 1986, Use of radiolarian biostratigraphy in stratigraphic problems in the Otuk Formation: 978 , p. 13-16.

Repenning, C.A., 1978, Fossil reconnaissance study, eastern NPRA: 772-B, p. B27.

Repetski, J.E., Carter, Claire, Harris, A.G., and Dutro, J.T., Jr., 1987, Ordovician and Silurian fossils from the Doonerak anticlinorium, central Brooks Range, Alaska: 998 , p. 40-42.

Sohn, I.G., 1984, Tethyan marine Triassic ostracodes in northeastern Alaska: 939 , p. 21-23.

Spicer, R.A., and Parrish, J.T., 1987, Plant megafossils, vertebrate remains, and paleoclimate of the Kogosukruk Tongue (Late Cretaceous), North Slope, Alaska: 998 , p. $47-48$.

\section{Petrology; petrography}

Ahlbrandt, T.S., and Huffman, A.C., 1978, Cretaceous Nanushuk Group, North Slope, Alaska: $772-B$, p. B 13-B 15 .

Armstrong, A.K., 1982, Petrography and cathode luminescence of carbonate rocks at Bornite, Alaska: 844 , p. 38-40.

Bartsch-Winkler, Susan, and Huffman, A.C., 1981, Compositional variation in sandstones of the Nanushuk Group, Arctic North Slope: 823-B, P. B6-B8.

Bird, K.J., 1977, Late Paleozoic carbonates from the south-central Brooks Range: 751-B, P. B19-B 20 .

Frank, C.O., and Zimmerman, Jay, 1982, Petrography of nonultramafic rocks from the Avan Hills complex, De Long Mountains, Alaska: 844, p. 22-27.

Loney, R.A., and Himmelberg, G.R., 1985, Ophiolitic ultramafic rocks of the Jade Mountains-Cosmos Hills area, southwestern Brooks Range: 967, p. 13-15.

Zayatz, M.R., 1987, Petrography of the Baird Mountains schistose 1ithologies, northwestern Alaska: 998, p. 49-52.

Zimmerman, Jay, Frank, C.0., and Bryn, Sean, 1981, Mafic rocks in the Avan Hills ultramafic complex, De Long Mountains: 823-B, p. B14-B15.

Zimmerman, Jay, and Soustek, P.G., 1979, The Avan Hills ultramafic complex, De Long Mountains, Alaska: $804-B$, P. B8-B 11 .

\section{Quaternary geology}

Brigham, J.K., 1984, Marine stratigraphy and amino acid geochronology of the Gubik Formation, western Arctic Coastal Plain, Alaska: 939, p. 5-9. 
Brouwers, E.M., Marincovich, Louie, Jr., and Hopkins, D.M., 1984, Paleoenvironmenta1 record of $P$ leistocene transgressive events preserved at skull Cliff, northern Alaska: 939 , p. 9-12.

Carter, L.D., and Galloway, J.P., 1979, Arctic Coastal Plain pingos in National Petroleum Reserve in Alaska: 804-B, P. B33-B34. 1979, Southward-progressing stabilization of Holocene eolian sand on the western Arctic Coastal Plain: 804-B, p. B37-B39. 1982, Terraces of the Colville Delta region, Alaska: 844, p. 49-51.

Carter, L.D., Marincovich, Louie, Jr., Brouwers, E.M., and Forester, R.M., 1979, Paleogeography of a Pleistocene coastline, Alaskan Arctic Coastal Plain: 804-B, P. B39-B41.

Carter, L.D., and Robinson, S.W, 1981, Minimum age of beach deposits north of Teshekpuk Lake, Alaskan Arctic Coastal Plain: 823-B, P. B8-B9.

Galloway, J.P., 1982, Grain-size analyses of 20 eolian sand samples from northern Alaska: 844 , p. 51-53.

Galloway, J.P., and Koster, E.A., 1984, Comparison of grain-size statistics from two northern Alaska dune fields: 868 , p. 20-21.

Hamilton, T.D., 1977, Surficial geology of the east-central Brooks Range: 751-B, p. B15-B16.

1978, Late Cenozoic stratigraphy of the south-central Brooks Range: 772-B, p. B36-B38.

1979, Late Cenozoic glaciations and erosion intervals, north-central Brooks Range: 804-B, P. B27-B29.

1981, Episodic Holocene alluviation in the central Brooks Range--Chronology, correlations, and climatic implications: 823-B, p. B21-B24.

Hamilton, T.D., Ashley, G.M., Reed, K.M., and Van Etten, D.P., 1984, Stratigraphy and sedimentology of Epiguruk Bluff--A preliminary account: 939, p. 12-14.

Hamilton, T.D., and Hopkins, D.M., 1982, Correlation of northern Alaska glacial deposits--A provisional stratigraphic framework: 844, p. 15-18.

Hamilton, T.D., Lancaster, G.A. and Trimble, D.A., 1987, Glacial advance of late Wisconsin (Itkillik II) age in the upper Noatak River Valley--A radiocarbondated stratigraphic record: 998 , p. 35-39.

Hamilton, T.D., and Thorson, R.M., 1976, Surficial geologic mapping in the Philip Smith Mountains and Chandalar quadrangles, Brooks Range: 733, p. 9-10.

Hamilton, T.D., and Van Etten, D.P., 1984, Late Pleistocene glacial dams in the Noatak Valley: 868 , p. 21-23.

Hopkins, D.M., and Robinson, S.W., 1979, Radiocarbon dates from the Beaufort and Chukchi Sea coasts: 804-B, P. B44-B46.

Morgan, A.V., Morgan, Anne, and Carter, L.D., 1979, Paleoenvironmental interpretation of a fossil insect fauna from bluffs along the lower Colville River, Alaska: 804-B, P. B41-B44.

Nelson, R.E., 1981, Paleoenvironments during deposition of a section of the Gubik Formation exposed along the lower Colville River, North Slope: 823-B, P. B9-B11.

Repenning, C.A., 1978, Fossil reconnaissance study, eastern NPRA: 772-B, P. B27.

Williams, J.R., 1979, Stratigraphy of the Gubik Formation at Skull Cliff, northern Alaska: 804-B, P. B31-B33.

Williams, J.R., Carter, L.D., and Yeend, W.E., 1978, Coastal plain deposits of NPRA: $772-B$, P. B20-B22. 


\section{Renote sensing}

Cathrall, J.B., 1982, Evidence from stream-sediment geochemical and biogeochemical data, mineral occurrences, and Landsat images for potential mineralized targets in the Brooks Range, Alaska: 844 , p. 41.

Grybeck, D.J., Cathral1, J.B., LeCompte, J.R., and Cady, J.W., 1985, Buried felsic plutons in Upper Devonian redbeds, central Brooks Range: 945, p. 8-10.

LeCompte, J.R., and Steele, W.C., 1981, Landsat data interpretation in the southcentral Brooks Range and in southeastern Alaska: 823-B, p. B1-B3.

Morrissey, L.A.,. and Ennis, R.A., 1979, Vegetation mapping of the National Petroleum Reserve in Alaska using Landsat digital data: 804-B, p. B50-B51.

\section{Sedimentary geology}

Ahlbrandt, T.S., and Huffman, A.C., 1978, Cretaceous Nanushuk Group, North Slope, Alaska: 772-B, p. B13-B15.

Armstrong, A.K., and Mamet, B.L., 1977, Carboniferous microfacies, microfossils, and corals, Lisburne Group, arctic Alaska: 751-B, p. B18.

1977, Mississippian microfacies of the Lisburne Group, Endicott Mountains, arctic Alaska: $751-B$, P. B18-B19.

Brigham, J.K., 1984, Marine stratigraphy and amino acid geochronology of the Gubik Formation, western Arctic Coastal Plain, Alaska: 939, p. 5-9.

Brosge, W.P., Reiser, H.N., and Dutro, J.T., Jr., 1981, Significance of Middle Devonian clastic rocks in the eastern Brooks Range, Alaska: 823-B, P. B24-B 25 .

Brouwers, E.M., Marincovich, Louie, Jr., and Hopkins, D.M., 1984, Paleoenvi ronmental record of $\mathrm{Pleistocene} \mathrm{transgressive} \mathrm{events} \mathrm{preserved} \mathrm{at} \mathrm{Skull} \mathrm{Cliff,} \mathrm{northern}$ Alaska: 939, p. 9-12.

Carter, L.D., and Galloway, J.P., 1979, Southward-progressing stabilization of Holocene eolian sand on the western Arctic Coastal Plain: 804-B, P. B37-B39.

Carter, L.D., Repenning, C.A., Marincovich, L.N., Hazel, J.E., Hopkins, D.M., McDouga11, Kristin, and Naeser, C.W., 1977, Gubik and pre-Gubik Cenozoic deposits along the Colville River near Ocean Point, North Slope, Alaska: 751-B, P. B12-B14.

Carter, L.D., and Robinson, S.W., 1981, Minimum age of beach deposits north of Teshekpuk Lake, Alaskan Arctic Coastal Plain: 823-B, p. B8-B9.

Detterman, R.L., and Spicer, R.A., 1981, New stratigraphic assignment for rocks along Igilatvik (Sabbath) Creek, William 0. Douglas Arctic Wildlife Range, Alaska: $823-B$, P. B11-B 12 .

Dutro, J.T., Jr., Brosge, W.P., and Reiser, H.N., 1977, Upper Devonian depositional history, central Brooks Range, Alaska: 751-B, p. B16-B18.

Ellersieck, Inyo, Tailleur, I.L., Mayfield, C.F., and Curtis, S.M., 1979, A new find of Upper Cretaceous or Tertiary sedimentary rocks in the Noatak Valley: 804-B, p. B13.

Galloway, J.P., 1982, Grain-size analyses of 20 eolian sand samples from northern Alaska: 844, p. 51-53.

Galloway, J.P., and Koster, E.A., 1984, Comparison of grain-size statistics from two northern Alaska dune fields: 868, p. 20-21.

Hamilton, T.D., 1978, Late Cenozoic stratigraphy of the south-central Brooks Range: $772-B$, P. B36-B 38 . 1979, Late Cenozoic glaciations and erosion intervals, north-central Brooks Range: $804-B$, P. B 27-B29. 1981, Episodic Holocene alluviation in the central Brooks Range--Chronology, correlations, and climatic implications: 823-B, p. B21-B24. 
Hamilton, T.D., Ashley, G.M., Reed, K.M., and Van Etten, D.P., 1984, Stratigraphy and sedimentology of Epiguruk Bluff--A preliminary account: 939 , p. 12-14.

Hamilton, T.D., Lancaster, G.A. and Trimble, D.A., 1987, Glacial advance of late Wisconsin (Itkillik II) age in the upper Noatak River Valley--A radiocarbondated stratigraphic record: 998 , p. 35-39.

Hopkins, D.M., Hartz, R.W., and Robinson, S.W., 1979, Record of a prehistoric storm surge in the Wainwright Inlet-Kuk River area: 804-B, P. B29-B31.

Huffman, A.C., and Ahlbrandt, T.S., 1979, The Cretaceous Nanushuk Group of the western and central North Slope, Alaska: 804-B, P. B46-B50.

Hunter, R.E., and Fox, J.E., 1976, Interpretation of depositional environments in the Fortress Mountain Formation, central Arctic Slope: 733, p. 30-31.

Mayfield, C.F., Tailleur, I.L., Mull, C.G., and Silberman, M.L., 1978, Granitic clasts from Upper Cretaceous conglomerate in the northwestern Brooks Range: $772-B$, P. B $11-B 13$.

Molenaar, C.M., 1981, Depositional history of the Nanushuk Group and related strata: 823-B, p. B4-B6.

Molenaar, C.M., Egbert, R.M., and Krystinik, L.F., 1982, Depositional facies and reservoir potential of the Fortress Mountain Formation, central North Slope: 844 , p. 32-33.

Molenaar, C.M., Huffman, A.C., and Kirk, A.R., 1982, Cretaceous-lower Tertiary depositional relations, northeastern Alaska: 844, p. 33-35.

Moore, T.E., and Nilsen, T.H., 1985, Sedimentology of meandering-stream cycles, upper part of the Ear Peak Member of the Kanayut Conglomerate, central Brooks Range: 967 , p. 15-19.

Moore, T.E., Nilsen, T.H., Grantz, Arthur, and Tailleur, I.L., 1984, Parautochthonous Mississippian marine and nonmarine strata, Lisburne Peninsula, Alaska: 939, p. 17-21.

Mul1, C.G., and Tailleur, I.L., 1977, Sadlerochit(?) Group in the Schwatka Mountains, southcentral Brooks Range: 751-B, P. B27-B29.

Mull, C.G., Tailleur, I.L., Mayfield, C.F., and Pessel, G.H., 1976, New structural and stratigraphic interpretations, central and western Brooks Range and Arctic Slope: 733 , p. 24-26.

Nelson, R.E., 1981, Paleoenvironments during deposition of a section of the Gubik Formation exposed along the lower Colville River, North Slope: 823-B, p. B9-B11.

Nelson, S.W., and Grybeck, Donald, 1978, The Arrigetch Peaks and Mount Igikpak plutons, Survey Pass quadrangle: 772-B, p. B7-B9.

Nilsen, T.H., Brosge, W.P., and Dutro, J.T., Jr., 1985, New reference section of the Noatak Sandstone, Nimiuktuk River, Misheguk Mountain quadrangle, central Brooks Range: 945 , p. 10-13.

Nilsen, T.H., Brosge, W.P., Dutro, J.T., Jr., and Moore, T.E., 1981 , Depositional model for the fluvial Upper Devonian Kanayut Conglomerate, Brooks Range, Alaska: $823-B, P . B 20-B 21$.

Nilsen, T.H., and Moore, T.E., 1984, The Kanayut Conglomerate in the westernmost Brooks Range, Alaska: 868, p. 12-16.

Plafker, George, Hudson, Travis, and Jones, D.L., 1978, Upper Triassic radiolarian chert from the Kobuk volcanic sequence in the southern Brooks Range: 772- $B$, P. B45-B47.

Reed, K.M., and Blome, C.D., 1986, Use of radiolarian biostratigraphy in stratigraphic problems in the Otuk Formation: 978, p. 13-16.

Repetski, J.E., Carter, Claire, Harris, A.G., and Dutro, J.T., Jr., 1987, Ordovician and Silurian fossils from the Doonerak anticlinorium, central Brooks Range, Alaska: 998 , p. 40-42. 
Spicer, R.A., and Parrish, J.T., 1987, Plant megafossils, vertebrate remains, and paleoclimate of the Kogosukruk Tongue (Late Cretaceous), North Slope, Alaska: 998 , p. 47-48.

Tailleur, I.L., Mayfield, C.F., and Ellersieck, I.F., 1977, Late Paleozoic sedimentary sequence, southwestern Brooks Range: 751-B, P. B25-B27.

Williams, J.R., 1979, Stratigraphy of the Gubik Formation at Skull Cliff, northern Alaska: 804-B, p. B31-B33.

Williams, J.R., Carter, L.D., and Yeend, W.E., 1978, Coastal plain deposits of NPRA: $772-B, P . B 20-B 22$.

\section{Structural geology; tectonics}

Bird, K.J., Connor, C.L., Tailleur, I.L., Silberman, M.L., and Christie, J.L., 1978, Granite on the Barrow arch, northeast NPRA: 772-B, p. B24-B 25 .

Churkin, Michael, Jr., Nokleberg, W.J., and Huie, Carl, 1979, Tectonic model for the western Brooks Range, Alaska: 804-B, P. B22-B25.

Dutro, J.T., Jr., Palmer, A.R., Repetski, J.E., Jr., and Brosge, W.P., 1984, The Doonerak anticlinorium revisited: 868, p. 17-19.

Ellersieck, Inyo, Mayfield, C.F., Tailleur, I.L., and Curtis, S.M., 1979, Thrust sequence in the Misheguk Mountain quadrangle, Brooks Range, Alaska: 804-B, P. B8.

Giovanetti, Dennis, and Bird, K.J., 1978, Geophysical profiles through the ShaviovikEchooka River region: 772-B, p. B32-B33.

Grybeck, Donald, and Nokleberg, W.J., 1979, Metallogeny of the Brooks Range, Alaska: 804-B, p. B19-B22.

Loney, R.A., and Himmelberg, G.R., 1985, Ophiolitic ultramafic rocks of the Jade Mountains-Cosmos Hills area, southwestern Brooks Range: 967, p. 13-15.

Mul1, C.G., 1977, Apparent south vergent folding and possible nappes in Schwatka Mountains: 751-B, P. B29-B30.

Mull, C.G., Tailleur, I.L., Mayfield, C.F., and Pessel, G.H., 1976, New structural and stratigraphic interpretations, central and western Brooks Range and Arctic Slope: 733 , p. 24-26.

Nelson, S.W., and Grybeck, Donald, 1978, The Arrigetch Peaks and Mount Igikpak plutons, Survey Pass quadrangle: $772-B$, P. B7-B9. 1979, Tectonic significance of metamorphic grade distribution, survey Pass quadrangle, Alaska: 804-B, p. B16-B 17 .

Nelson, S.W., Nokleberg, W.J., Miller-Hoare, Martha, and Mullen, M.W., 1979, Siniktanneyak Mountain ophiolite: 804-B, P. B14-B16.

Nilsen, T.H., Brosge, W.P., Moore, T.E., Dutro, J.T., Jr., and Balin, Donna, 1982, Significance of the Endicott Group for tectonic models of the Brooks Range: 844, p. 28-32.

Zimmerman, Jay, and Frank, C.0., 1982, Possible obduction-related metamorphic rocks at the base of the ultramafic zone, Avan Hills complex, De Long Mountains: 844, p. 27-28.

\section{Surficial geology}

Hamilton, T.D., 1977, Surficial geology of the east-central Brooks Range: 751-B, P. B15-B16.

Hamilton, T.D., and Thorson, R.M., 1976, Surficial geologic mapping in the Philip Smith Mountains and Chandalar quadrangles, Brooks Range: 733, p. 9-10.

Hamilton, T.D., and Van Etten, D.P., 1984, Late Pleistocene glacial dams in the Noatak Valley: 868 , p. 21-23. 
Kachadoorian, Reuben, Crory, F.E., and Berg, D.L., 1978, Studies of proposed airfields at the Inigok and Tunalik well sites, NPRA: 772-B, p. B22-B24. 1979, Design of airfields in National Petroleum Reserve in Alaska: 804-B, P. B51-B52.

Meckel, J.P., 1976, Environmental data collection along proposed Canadian gas pipeline along coastal route in Alaska: 733, p. 23.

Williams, J.R., Carter, L.D., and Yeend, W.E., 1978, Coastal plain deposits of NPRA: $772-B$, P. B20-B22.

Williams, J.R., and Yeend, W.E., 1979, Deep thaw lake basins of the inner Arctic Coastal Plain, Alaska: 804-B, P. B35-B37.

Yeend, Warren, 1978, Surficial geology of the foothills and mountains of NPRA: $772-B$, P. B19-B 20 . 1984, Surficial geology of Lookout Ridge quadrangle: 939, p. 23-25.

\section{Volcanoes; volcanic rocks}

Reiser, H.N., Brosge, W.P., Dutro, J.T., Jr., and Detterman, R.L., 1979, Upper Paleozoic volcanic rocks in the eastern and central Brooks Range: 804-B, p. B25-B27. 


\section{West-Central Alaska}

Coal

Sloan, E.G., Shearer, G.B., Easton, James, and Almquist, Car1, 1978, Preliminary investigations of coal outcrops near Farewel1, Alaska: 772-B, P. B50.

\section{Economic geology}

Gamble, B.M., Ashley, R.P., and Pickthorn, W.J., 1985, Preliminary study of lode gold deposits, Seward Peninsula: 967, p. 27-29.

Hudson, Travis, Barker, Fred, and Arth, Joseph, 1978, Tin-granites of Seward Peninsula: 772-B, P. B44-B45.

Hudson, Travis, and Mays, R.E., 1976, Trace-element composition of biotite from a tin-granite complex, Seward Peninsula: 733, p. 36-37.

Johnson, B.R., Miller, T.P., and Karl, Susan, 1979, Uranium-thorium investigations of the Darby pluton, Seward Peninsula, Alaska: 804-B, p. B68-B70.

Miller, T.P., and Johnson, B.R., 1978, An occurrence of parsonite, a secondary uranium mineral, in alaskite of the Wheeler Canyon pluton: 772-B, p. B42-B44.

Nelson, C.H., Jenne, E.A., Larsen, B.R., and Sorg, D.H., 1976, Mercury dispersal in Kuskokwim River and Bay: 733, p. 43-44.

Staatz, M.H., and Miller, T.P., 1976, Uranium and thorium content of radioactive phases of the Zane Hills pluton: 733 , p. 39-41.

\section{General geology}

Chapman, R.M., 1976, Progress report on new geologic mapping in the Ruby quadrangle: 733 , p. 41-42.

Chapman, R.M., and Patton, W.W., Jr., 1978, Preliminary summary of the geology of the northwest part of the Ruby quadrangle: 772-B, P. B39-B41. 1979, Two upper Paleozoic sedimentary rock units identified in southwestern part of the Ruby quadrangle: 804-B, p. B59-B61.

Chapman, R.M., Patton, W.W., Jr., and Mol1, E.J., 1982, Preliminary summary of the geology in eastern part of Ophir quadrangle: 844, p. 70-72.

Dumoulin, J.A., and Till, A.B., 1985, Seacliff exposures of metamorphosed carbonate and schist, northern Seward Peninsula: 945, p. 18-22.

Humme1, C.L., 1976, Revised interpretation of regional geological controls of mineralization in southwest Seward Peninsula, west-central Alaska: 733, p. 37-39.

Mo11, E.J., and Patton, W.W., Jr., 1982, Preliminary report on the Late Cretaceous and early Tertiary volcanic and related plutonic rocks in western Alaska: 844, p. 73-76.

Patton, W.W., Jr., and Mol1, E.J., 1984, Reconnaissance geology of the northern part of the Unalakleet quadrangle: 868 , p. 24-27.

\section{Geochemistry}

Church, S.E., Briskey, J.A., Delevaux, M.H., and LeHuray, A.P., 1985, Preliminary results of $\mathrm{Pb}$-isotope analyses of deposits from the Seward Peninsula: 967, P. 24-27.

Gamble, B.M., Ashley, R.P., and Pickthorn, W.J., 1985, Preliminary study of lode gold deposits, Seward Peninsula: 967, p. 27-29.

Hudson, Travis, and Mays, R.E., 1976, Trace-element composition of biotite from a tin-granite complex, Seward Peninsula: 733, p. 36-37. 
King, H.D., 1984, Geochemical survey of the Solomon and Bendeleben quadrangles, Seward Peninsula, Alaska: 939, p. 33-37.

Silberman, M.L., O'Leary, R.M., Gray, L.B., and Patton, W.W., Jr., 1984, Trace-metal anomalies associated with silicification and argillic alteration in a rhyolite flow-dome complex in volcanic rocks of the Nowitna River area, Medfra quadrangle, Alaska: 868 , p. 32-34.

Staatz, M.H., and Miller, T.P., 1976, Uranium and thorium content of radioactive phases of the Zane Hills pluton: 733, p. 39-41.

\section{Geochronology}

Church, S.E., Briskey, J.A., Delevaux, M.H., and LeHuray, A.P., 1985, Preliminary results of $\mathrm{Pb}-$ isotope analyses of deposits from the Seward Peninsula: 967, p. 24-27.

Dillon, J.T., Patton, W.W., Jr., Mukasa, S.B., Tilton, G.R., Blum, Joel, and Moll, E.J., 1985, New radiometric evidence for the age and thermal history of the metamorphic rocks of the Ruby and Nixon Fork terranes, west-central Alaska: 945, p. 13-18.

Patton, W.W., Jr., Moll, E.J., Lanphere, M.A., and Jones, D.L., 1984, New age data for the Kaiyuh Mountains, west-central Alaska: 868, p. 30-32.

Silberman, M.L., Moll, E.J., Chapman, R.M., Patton, W.W., Jr., and Connor, C.L., 1979, Potassium-argon age of granitic and volcanic rocks from the Ruby, Medfra, and adjacent quadrangles, west-central Alaska: 804-B, P. B63-B66.

\section{Geophysics}

Cady, J.W., 1986, Geophysics of the Yukon-Koyukuk province: 978, p. 21-25.

\section{Geothermal studies}

Dillon, J.T., Patton, W.W., Jr., Mukasa, S.B., Tilton, G.R., Blum, Joel, and Moll, E.J., 1985, New radiometric evidence for the age and thermal history of the metamorphic rocks of the Ruby and Nixon Fork terranes, west-central Alaska: 945, p. $13-18$.

\section{Hydrology}

Nelson, C.H., Jenne, E.A., Larsen, B.R., and Sorg, D.H., 1976, Mercury dispersal in Kuskokwim River and Bay: 733, p. 43-44.

\section{Marine geology}

Nelson, C.H., Jenne, E.A., Larsen, B.R., and Sorg, D.H., 1976, Mercury dispersal in Kuskokwim River and Bay: 733, p. 43-44.

\section{Metanorphic geology}

Angeloni, L.M., and Miller, M.L., 1985, Greenschist facies metamorphic rocks of north-central Iditarod quadrangle: 967 , p. 19-21.

Dumoulin, J.A., and Till, A.B., 1985, Seacliff exposures of metamorphosed carbonate and schist, northern Seward Peninsula: 945, p. 18-22.

Miller, M.L., and Bundtzen, T.K., 1985, Metamorphic rocks in the western Iditarod quadrangle, west-central Alaska: 945, p. 24-28. 
Patton, W.W., Jr., and Dutro, J.T., Jr., 1979, Age of the metamorphic complex in the northern Kuskokwim Mountains, west-central Alaska: 804-B, P. B61-B63.

Silberman, M.L., Moll, E.J., Patton, W.W., Jr., Chapman, R.M., and Connor, C.L., 1979, Precambrian age of metamorphic rocks from the Ruby province, Medfra and Ruby quadrangles--Preliminary evidence from radiometric data: 804-B, p. B66-B68.

\section{Oil and gas}

Palmer, I.F., Bolm, J.G., Flett, T.0., Lyle, W.M., Morehouse, J.A., Riehle, J., and Emmel, K.S., 1979, Hydrocarbon reservoir and source rock characteristics from selected areas of western Alaska: $804-B$, p. B86.

\section{Paleontology}

Chapman, R.M., Churkin, Michael, Jr., Carter, Claire, and Trexler, J.H., Jr., 1981, Ordovician graptolites and early Paleozoic radiolarians in the Lake Minchumina area date a regional shale and chert belt: 823-B, P. B32-B34.

Chapman, R.M., and Patton, W.W., Jr., 1979, Two upper Paleozoic sedimentary rock units identified in southwestern part of the Ruby quadrangle: 804-B, p. B59-B61.

Dutro, J.T., Jr., and Patton, W.W., Jr., 1981, Lower Paleozoic platform carbonate sequence in the Medfra quadrangle, west-central Alaska: 823-B, P. B42-B44.

Mammay, S.H., and Reed, B.L., 1984, Permian plant megafossils from the conglomerate of Mount Dall, central Alaska Range: 868, p. 98-102.

Patton, W.W., Jr., 1976, Newly discovered Upper Triassic and Lower Cretaceous strata in the northern Kuskokwim Mountains: 733, p. 42-43.

\section{Petrology; petrography}

Dumoulin, J.A., and Till, A.B., 1985, Seacliff exposures of metamorphosed carbonate and schist, northern Seward Peninsula: 945, p. 18-22.

Hudson, Travis, and Mays, R.E., 1976, Trace-element composition of biotite from a tin-granite complex, Seward Peninsula: 733, p. 36-37.

Johnson, B.R., Miller, T.P., and Karl, Susan, 1979, Uranium-thorium investigations of the Darby pluton, Seward Peninsula, Alaska: 804-B, p. B68-B70.

Loney, R.A., and Himmelberg, G.R., 1984, Preliminary report on ophiolites in the Yuki River and Mount Hurst areas, west-central Alaska: 868, p. 27-30. 1985, Distribution and character of the peridotite-layered gabbro complex of the southeastern Yukon-Koyukuk ophiolite belt: 945, p. 46-48.

Miller, T.P., and Johnson, B.R., 1978, An occurrence of parsonite, a secondary uranium mineral, in alaskite of the Wheeler Canyon pluton: 772-B, P. B42-B44.

Staatz, M.H., and Miller, T.P., 1976, Uranium and thorium content of radioactive phases of the Zane Hills pluton: 733, p. 39-41.

Throckmorton, M.L., and Hummel, C.L., 1979, Quartzofeldspathic, mafic, and ultramafic granulites identified in the Kigluaik Mountains, Seward Peninsula, Alaska: $804-B$, P. B $70-B 72$.

\section{Quaternary geology}

Ager, T.A., and Bradbury, Platt, 1982, Quaternary history of vegetation and climate of the Yukon Delta-Norton Sound area: 844, p. 78-80.

Kaufman, D.S., 1985, Windy Creek and Crater Creek faults, Seward Peninsula: 945, p. $22-24$. 


\section{Sedimentary geology}

Chapman, R.M., and Patton, W.W., Jr., 1979, Two upper Paleozoic sedimentary rock units identified in southwestern part of the Ruby quadrangle: 804-B, p. B59-B61.

Dutro, J.T., Jr., and Patton, W.W., Jr., 1981, Lower Paleozoic platform carbonate sequence in the Medfra quadrangle, west-central Alaska: 823-B, p. B42-B44.

Nilsen, T.H., and Patton, W.W., Jr., 1984, Cretaceous fluvial to deep-marine deposits of the central Yukon-Koyukuk basin, Alaska: 939, p. 37-40.

Palmer, I.F., Bolm, J.G., Flett, T.0., Lyle, W.M., Morehouse, J.A., Riehle, J., and Emmel, K.S., 1979, Hydrocarbon reservoir and source rock characteristics from selected areas of western Alaska: $804-B$, p. B86.

Patton, W.W., Jr., 1976, Newly discovered Upper Triassic and Lower Cretaceous strata in the northern Kuskokwim Mountains: 733, p. 42-43. 1977, Pre-Ordovician unconformity in central Alaska: 751-B, p. B39.

Patton, W.W., Jr., Dutro, J.T., Jr., and Chapman, R.M., 1977, Late Paleozoic and Mesozoic stratigraphy of the Nixon Fork area, Medfra quadrangle, Alaska: 751-B, P. B38-B39.

Patton, W.W., Jr., and Moll, E.J., 1982, Structural and stratigraphic sections along a transect between the Alaska Range and Norton Sound: 844, p. 76-78.

\section{Structural geology; tectonics}

Box, S.E., Patton, W.W., Jr., and Carlson, Christine, 1985, Early Cretaceous evolution of the northeastern Yukon-Koyukuk basin, west-central Alaska: 967, p. 21-24.

Dumoulin, J.A., and Till, A.B., 1985, Seacliff exposures of metamorphosed carbonate and schist, northern Seward Peninsula: 945, p. 18-22.

Dutro, J.T., Jr., and Patton, W.W., Jr., 1981, Lower Paleozoic platform carbonate sequence in the Medfra quadrangle, west-central Alaska: 823-B, p. B42-B44.

Hudson, Travis, and Plafker, George, 1978, Kigluaik and Bendeleben faults, Seward Peninsula: 772-B, p. B47-B50.

Kaufman, D.S., 1985, Windy Creek and Crater Creek faults, Seward Peninsula: 945, p. 22-24.

Loney, R.A., and Himmelberg, G.R., 1984, Preliminary report on ophiolites in the Yuki River and Mount Hurst areas, west-central Alaska: 868, p. 27-30. 1985, Distribution and character of the peridotite-layered gabbro complex of the southeastern Yukon-Koyukuk ophiolite belt: 945, p. 46-48.

Patton, W.W., Jr., 1978, Juxtaposed continental and oceanic-island arc terranes in the Medfra quardangle, west-central Alaska: 772-B, p. B38-B39.

Patton, W.W., Jr., and Moll, E.J., 1982, Structural and stratigraphic sections along a transect between the Alaska Range and Norton Sound: 844, p. 76-78.

\section{Surficial geology}

Chapman, R.M., and Patton, W.W., Jr., 1978, Landslides near Melozitna River canyon: $772-B$, p. B41-B42, B43.

\section{Volcanoes; volcanic rocks}

Mol1, E.J., and Patton, W.W., Jr., 1982, Preliminary report on the Late Cretaceous and early Tertiary volcanic and related plutonic rocks in western Alaska: 844, p. 73-76. 
Silberman, M.L., Moll, E.J., Chapman, R.M., Patton, W.W., Jr., and Connor, C.L., 1979, Potassium-argon age of granitic and volcanic rocks from the Ruby, Medfra, and adjacent quadrangles, west-central Alaska: 804-B, p. B63-B66.

Silberman, M.L., O'Leary, R.M., Gray, L.B., and Patton, W.W., Jr., 1984, Trace-metal anomalies associated with silicification and argillic alteration in a rhyolite flow-dome complex in volcanic rocks of the Nowitna River area, Medfra quadrangle, Alaska: 868 , p. 32-34. 


\section{East-Central Alaska}

\section{Economic geology}

Antweiler, J.C., Tripp, R.B., Cathra11, J.B., and Mosier, E.L., 1985, Studies of gold in the Chandalar and Koyukuk districts, Wiseman and Bettles quadrangles--A progress report: 945 , p. 28-29.

Foster, H.L., and O'Leary, R.M., 1982, Gold found in bedrock of Lost Chicken Creek gold placer mine, Fortymile area, Alaska: 844, p. 62-63.

Jones, G.M., Menzie, W.D., and Foster, H.L., 1985, Statistical discrimination between potential tin- and uranium-bearing areas in east-cental Alaska on the basis of stream-sediment trace-element geochemistry: 945, p. 40-46.

Keith, T.E.C., Page, N.J., Oscarson, R.L., and Foster, H.L., 1987, Platinum-group element concentrations in a biotite-rich clinopyroxenite suite, Eagle $\mathrm{C}-3$ quadrangle, Alaska: 998 , p. 62-66.

Light, T.D., Cady, J.W., Weber, F.R., McCammon, R.B., and Rinehart, C.D., 1987, Sources of placer gold in the southern part of the White Mountains Recreation Area, east-central Alaska: 998 , p. 67-69.

Menzie, W.D., Foster, H.L., and Mosier, D.L., 1981, Metalliferous mineral resource potential of the Big Delta quadrangle: 823-B, P. B38-B39.

Menzie, W.D., Reed, B.L., and Keith, T.E.C., 1986, Lime Peak--An evolved granite with tin-enriched alteration: 978 , p. 25-27.

Tripp, R.B., Detra, D.E., and Nishi, J.M., 1982, Mineralized zones in bedrock near Miller Creek, Circle quadrangle: 844, p. 62-63.

Yeend, W.E, 1982, Placers and placer mining, Circle District: 844, p. 64 . 1984, Gold in Tertiary(?) rocks, Circle quadrangle, Alaska: 868, p. 65-66. 1987, Placer gold related to mafic schist(?) in the Circle District, Alaska: 998, p. $74-76$.

\section{General geology}

Albert, N.R.D., and Steele, W.C., 1977, LANDSAT data interpretation, McCarthy, Tanacross, and Talkeetna quadrangles: 751-B, P. B58-B61.

Chapman, R.M., Trexler, J.H., Jr., Churkin, Michael, Jr., and Weber, F.R., 1985, New concepts of the Mesozoic flysch belt in east-central Alaska: 945, p. 29-32.

Chapman, R.M., and Yeend, Warren, 1981, Geologic reconnaissance of the east half of Kantishna River quadrangle and adjacent areas: 823-B, P. B30-B32.

Dover, J.H., and Miyaoka, R.T., 1985, Major rock packages of the Ray Mountains, Tanana and Bettles quadrangles: 945, p. 32-36.

Foster, H.L., and Keith, T.E.C., 1987, Preliminary geology, including the Tintina fault system, of part of the southwestern Charley River quadrangle, Alaska: 998 , p. $59-61$.

Foster, H.L., and Weber, F.R., 1976, Reconnaissance geologic mapping in the eastern Big Delta quadrangle: 733 , p. $34-36$.

Foster, H.L., Weber, F.R., and Dutro, J.T., Jr., 1984, Paleozoic limestones of the Crazy Mountains and vicinity, Circle quadrangle, east-central Alaska: 868, p. 60-62.

Foster, H.L., Weber, F.R., and Keith, T.E.C., 1979, Metamorphic rock units of the southern part of the Circle quadrangle, east-central Alaska: 804-B, P. B54-B55.

\section{Geochemistry}

Chapman, R.M., 1977, Geochemical anomalies in bedrock, west half of Kantishna River quadrangle: $751-B$, P. B35-B 36 . 
Dusel-Bacon, Cynthia, 1984, Trace-element evidence for the tectonic affinities of some amphibolites from the Yukon-T anana Upland, east-central Alaska: 868, p. 50-54.

Jones, G.M., Menzie, W.D., and Foster, H.L., 1985, Statistical discrimination between potential tin- and uranium-bearing areas in east-cental Alaska on the basis of stream-sediment trace-element geochemistry: 945, p. 40-46.

Marsh, S.P., 1976, Geochemical reconnaissance of the Chandalar quadrangle: 733, p. 33-34.

Tripp, R.B., Detra, D.E., and Nishi, J.M., 1982, Mineralized zones in bedrock near Miller Creek, Circle quadrangle: 844, p. 62-63.

Wheeler, K.L., Forbes, R.B., Weber, F.R., and Rinehart, C.D., 1987, Lithostratigraphy, petrology, and geochemistry of the Ordovician Fossil Creek Volcanics, White Mountains, east-central Alaska: 998, p. 70-73.

\section{Geochronology}

Aleinikoff, J.N., Dusel-Bacon, Cynthia, and Foster, H.L., 1981, Geochronologic studies in the Yukon-Tanana Upland, east-central Alaska: 823-B, P. B34-B37. 1984, Uranium-lead isotopic ages of zircon from sillimanite gneiss and implications for Paleozoic metamorphism, Big Del ta quadrangle, east-central Alaska: 868 , p. 45-48.

Aleinikoff, J.N., Foster, H.L., Nokleberg, W.J., and Duse1-Bacon, Cynthia, 1984, Isotopic evidence from detrital zircons for Early Proterozoic crustal material, east-central Alaska: 868 , p. 43-45.

Foster, H.L., 1981, A minimum age for Prindle Volcano, Yukon-Tanana Upland: 823-B, P. B37-B38.

Hamilton, T.D., and Bischoff, J.L., 1984, Uranium-series dating of fossil bones from the Canyon Creek vertebrate locality in central Alaska: 939, p. 26-29.

Miller, T.P., and Lanphere, M.A., 1981, K-Ar age measurements on obsidian from the Little Indian River locality in interior Alaska: 823-B, P. B39-B42.

\section{Geophysics}

Light, T.D., Cady, J.W., Weber, F.R., McCammon, R.B., and Rinehart, C.D., 1987, Sources of placer gold in the southern part of the White Mountains Recreation Area, east-central Alaska: 998, p. 67-69.

\section{Geothermal studies}

Keith, T.E.C., and Foster, H.L., 1979, Big Windy Creek hot springs, Circle A-1 quadrangle, Alaska: 804-B, p. B55-B57.

Keith, T.E.C., Presser, T.S., and Foster, H.L., 1981, New chemical and isotope data for the hot springs along Big Windy Creek, Circle A-1 quadrangle, Alaska: $823-B$, P. B25-B28.

\section{Hydrology}

Burroughs, R.L., Emmett, W.W., and Parks, Bruce, 1982, Sediment transport in the Tanana River in the vicinity of Fairbanks, Alaska: 844, p. 67-69.

Keith, T.E.C., and Foster, H.L., 1979, Big Windy Creek hot springs, Circle A-1 quadrangle, Alaska: 804-B, p. B55-B57.

Keith, T.E.C., Presser, T.S., and Foster, H.L., 1981, New chemical and isotope data for the hot springs along $B i g$ Windy Creek, Circle A-1 quadrangle, Alaska: 823-B, P. B25-B28. 
Krumhardt, Andrea, 1979, Geohydrology of Fairbanks North Star Borough: 804-B, p. B59.

1982, Geohydrology of the Fairbanks North Star Borough, Alaska: 844, p. 68-69.

Nelson, G.L., 1976, Geohyrdrology of the Fairbanks North Star Borough: 733, p. 34 .

1977, Geohydrology of the Fairbanks-North Star Borough: 751-B, P. B36-B37.

1978, Geohydrology of the Del ta-Clearwater area: 772-B, p. B38.

1978, Geohydrology of the Fairbanks-North Star Borough: 772-B, P. B38.

Wilcox, D.E., 1979, Geohydrology of the Delta-Clearwater area: 804-B, P. B59.

\section{Metamorphic geology}

Aleinikoff, J.N., Dusel-Bacon, Cynthia, and Foster, H.L., 1984, Uranium-lead isotopic ages of zircon from sillimanite gneiss and implications for Paleozoic metamorphism, Big Delta quadrangle, east-central Alaska: 868, p. 45-48.

Burack, A.C., Laird, Jo, Foster, H.L., and Cushing, G.W., 1984, Metamorphic petrology of the Table Mountain area, Circle quadrangle, Alaska: 868, p. 54-57.

Dover, J.H., and Miyaoka, R.T., 1985, Major rock packages of the Ray Mountains, Tanana and Bettles quadrangles: 945 , p. 32-36. 1985, Metamorphic rocks of the Ray Mountains--Preliminary structural analysis and regional tectonic implications: 945 , p. 36-38.

Dusel-Bacon, Cynthia, and Bacon, C.R., 1984, Concordant bands of augen gneiss within metasedimentary rocks in the $\mathrm{Big}$ Del ta $\mathrm{C}-2$ quadrangle, east-central Alaska: 868 , p. 48-50.

Dusel-Bacon, Cynthia, Stern, T.W., Foster, H.L., and Bentz, J.L., 1979, Preliminary results of an augen gneiss study, Big Delta quadrangle: 804-B, p. B57-B59.

Foster, H.L., Weber, F.R., and Dusel-Bacon, Cynthia, 1977, Gneiss dome in the Big Delta C-4 quadrangle, Yukon-T anana Upland, Alaska: 751-B, P. B33.

Foster, H.L., Weber, F.R., and Keith, T.E.C., 1979, Metamorphic rock units of the southern part of the Circle quadrangle, east-central Alaska: 804-B, P. B54-B55.

Laird, Jo, and Foster, H.L., 1984, Description and interpretation of a mylonitic foliated quartzite unit and feldspathic quartz wacke (grit) unit in the Circle quadrangle, Alaska: 939 , p. 29-33.

Laird, Jo, Foster, H.L., and Weber, F.W., 1984, Amphibolite eclogite in the Circle quadrangle, Yukon-T anana Upland, Alaska: 868, p. 57-60.

Miyaoka, R.T., and Dover, J.H., 1985, Preliminary study of shear sense in mylonites, eastern Ray Mountains, T anana quadrangle: 967, p. 29-32.

\section{Paleontology}

Blodgett, R.B., Wheeler, K.L., Rohr, D.M., Harris, A.G., and Weber, F.R., 1987, A Late Ordovician age reappraisal for the Upper Fossil Creek Volcanics, and possible significance for glacio-eustasy: 998 , p. 54-58.

Churkin, Michael, Jr., Trexler, J.H., Jr., and Carter, Claire, 1982, Graptolites discovered in the Woodchopper Volcanics: 844, p. 53-56.

Foster, H.L., Cushing, G.W., Weber, F.R., Jones, D.L., Murchey, Benita, and Blome, C.D., 1984, Late Paleozoic and early Mesozoic radiolarians in the Circle quadrangle, east-central Alaska: 868, p. 62-64.

Foster, H.L., Jones, D.L., Keith, T.E.C., Wardlaw, Bruce, and Weber, F.R., 1978, Late Paleozoic radiolarians and conodonts found in chert of $B$ ig Del ta quadrangle: $772-B$, P. B34-B 36 .

Foster, H.L., Weber, F.R., and Dutro, J.T., Jr., 1984, Paleozoic limestones of the Crazy Mountains and vicinity, Circle quadrangle, east-central Alaska: 868, p. 60-62. 
Hamilton, T.D., and Bischoff, J.L., 1984, Uranium-series dating of fossil bones from the Canyon Creek vertebrate locality in central Alaska: 939, p. 26-29.

Jones, D.L., Silberling, N.J., Chapman, R.M., and Coney, P.J., 1984, New ages of radiolarian chert from the Rampart district, east-central Alaska: 868, p. 439-43.

\section{Petrology; petrography}

Burack, A.C., Laird, Jo, Foster, H.L., and Cushing, G.W., 1984, Metamorphic petrology of the Table Mountain area, Circle quadrangle, Alaska: 868, p. 54-57.

Dusel-Bacon, Cynthia, and Bacon, C.R., 1984, Concordant bands of augen gneiss within metasedimentary rocks in the $\mathrm{Big}$ Delta $\mathrm{C}-2$ quadrangle, east-central Alaska: 868 , p. 48-50.

Dusel-Bacon, Cynthia, Stern, T.W., Foster, H.L., and Bentz, J.L., 1979, Preliminary results of an augen gneiss study, Big Delta quadrangle: 804-B, P. B57-B59.

Keith, T.E.C., Barnes, Ivan, and Foster, H.L., 1981 , Laumontite occurrence in the Circle A-1 quadrangle, Alaska: 823-B, p. B28-B29.

Keith, T.E.C., and Foster, H.L., 1977, U1tramafic rocks near Volkmar Lake, Big Delta quadrangle, Yukon-T anana Upland, Alaska: 751-B, P. B32-B33.

Keith, T.E.C., Page, N.J., Oscarson, R.L., and Foster, H.L., 1987, P1atinum-group element concentrations in a biotite-rich clinopyroxenite suite, Eagle C-3 quadrangle, Alaska: 998, p. 62-66.

Laird, Jo, and Foster, H.L., 1984, Description and interpretation of a mylonitic foliated quartzite unit and feldspathic quartz wacke (grit) unit in the Circle quadrangle, Alaska: 939, p. 29-33.

Laird, Jo, Foster, H.L., and Weber, F.W., 1984, Amphibolite eclogite in the Circle quadrangle, Yukon-T anana Upl and, Al aska: 868, p. 57-60.

Menzie, W.D., Reed, B.L., and Keith, T.E.C., 1986, Lime Peak--An evolved granite with tin-enriched alteration: 978 , p. 25-27.

Wheeler, K.L., Forbes, R.B., Weber, F.R., and Rinehart, C.D., 1987, Lithostratigraphy, petrology, and geochemistry of the Ordovician Fossil Creek Volcanics, White Mountains, east-central Alaska: 998, p. 70-73.

\section{Quaternary geology}

Ager, T.A., 1982, Pollen studies of Quaternary-age lake sediments in the Tanana Valley, Alaska: 844 , p. 64-67.

Carter, L.D., and Galloway, J.P., 1984, Lacustrine and eolian deposits of Wisconsin age at Riverside Bluff in the upper Tanana River valley, Alaska: 868, p. 66-68.

Foster, H.L., 1981, A minimum age for Prindle Volcano, Yukon-Tanana Upland: 823-B, P. B 37-B 38 .

Hamilton, T.D., and Bischoff, J.L., 1984, Uranium-series dating of fossil bones from the Canyon Creek vertebrate locality in central Alaska: 939, p. 26-29.

Weber, F.R., and Ager, T.A., 1984, Glacial-lake deposits in the Mount Harper area, Yukon-T anana Upland: 868, p. 68-70.

Weber, F.R., and Foster, H.L., 1982, Tertiary(?) conglomerate and Quaternary faulting in the Circle quadrangle, Alaska: 844, p. 58-61.

\section{Remote sensing}

Albert, N.R.D., and Steele, W.C., 1977, LANDSAT data interpretation, McCarthy, Tanacross, and Talkeetna quadrangles: 751-B, P. B58-B61. 


\section{Sedimentary geology}

Blodgett, R.B., Wheeler, K.L., Rohr, D.M., Harris, A.G., and Weber, F.R., 1987, A Late Ordovician age reappraisal for the Upper Fossil Creek Volcanics, and possible significance for glacio-eustasy: 998, p. 54-58.

Carter, L.D., and Galloway, J.P., 1984, Lacustrine and eolian deposits of Wisconsin age at Riverside Bluff in the upper Tanana River valley, Alaska: 868, p. 66-68.

Weber, F.R., and Foster, H.L., 1982, Tertiary(?) conglomerate and Quaternary faulting in the Circle quadrangle, Alaska: 844, p. 58-61.

Wheeler, K.L., Forbes, R.B., Weber, F.R., and Rinehart, C.D., 1987, Lithostratigraphy, petrology, and geochemistry of the Ordovician Fossil Creek Volcanics, White Mountains, east-central Alaska: 998, p. 70-73.

\section{Structural geology; tectonics}

Chapman, R.M., Trexler, J.H., Jr., Churkin, Michael, Jr., and Weber, F.R., 1985, New concepts of the Mesozoic flysch belt in east-central Alaska: 945, p. 29-32.

Cushing, G.W., and Foster, H.L., 1984, Structural observations in the Circle quadrangle, Yukon-T anana Upl and, Alaska: 868, p. 64-65.

Cushing, G.W., Foster, H.L., Laird, Jo, and Burack, A.C., 1982, Description and preliminary interpretation of folds and faults in a small area in the Circle B-4 and B-5 quadrangles, Alaska: 844, p. 56-58.

Dover, J.H., and Miyaoka, R.T., 1985, Metamorphic rocks of the Ray Mountains-Preliminary structural analysis and regional tectonic implications: 945, p. 36-38.

Dusel-Bacon, Cynthia, 1984, Trace-element evidence for the tectonic affinities of some amphibolites from the Yukon-Tanana Upland, east-central Alaska: 868, p. 50-54.

Foster, H.L., and Cushing, G.W., 1985, Tertiary(?) folding in the Tanacross. quadrangle: 945 , p. 38-40.

Foster, H.L., Weber, F.R., and Dusel-Bacon, Cynthia, 1977, Gneiss dome in the Big Del ta C-4 quadrangle, Yukon-T anana Upland, Alaska: 751-B, p. B33.

Foster, H.L., Weber, F.R., and Dutro, J.T., Jr., 1984, Paleozoic limestones of the Crazy Mountains and vicinity, Circle quadrangle, east-central Alaska: 868, p. 60-62.

Hudson, Travis, Foster, H.L., and Weber, F.R., 1977, The Shaw Creek fault, eastcentral Alaska: 751-B, P. B33-B34.

Miyaoka, R.T., and Dover, J.H., 1985, Preliminary study of shear sense in mylonites, eastern Ray Mountains, Tanana quadrangle: 967, p. 29-32.

Weber, F.R., and Foster, H.L., 1982, Tertiary(?) conglomerate and Quaternary faulting in the Circle quadrangle, Alaska: 844, p. 58-61.

\section{Volcanoes; volcanic rocks}

Churkin, Michael, Jr., Trexler, J.H., Jr., and Carter, Claire, 1982, Graptolites discovered in the Woodchopper Volcanics: 844, p. 53-56.

Foster, H.L., 1981, A minimum age for Prindle Volcano, Yukon-Tanana Upland: 823-B, P. B37-B38.

Weber, F.R, 1982, Two new tephra localities in the Yukon-Tanana Upland: 844, p. 61-62. 


\section{Southwestern Alaska}

\section{Economic geology}

York, J.E., Wilson, F.H., and Gamble, B.M., 1985, Digital image processing techniques for detecting surface alteration--An application on the Alaska Peninsula: 945, p. 56-58.

\section{General geology}

Box, S.E., 1985, Geologic setting of high-pressure metamorphic rocks, Cape Newenham area, southwestern Alaska: 967 , p. 37-42.

Childs, J.R., Scholl, D.W., and Vallier, Tracy, 1981, Onshore and offshore studies, Amlia Island area, Aleutian Ridge: 823-B, p. B134-B138.

Detterman, R.L., Case, J.E., and Wilson, F.H., 1979, Paleozoic rocks on the Alaska Peninsula: 804-B, p. B85-B86.

Hoare, J.M., and Coonrad, W.L., 1977, Blue amphibole occurrences in southwestern Alaska: $751-\mathrm{B}$, P. B39-B40. 1978, New geologic map of the Goodnews-Hagemeister quadrangles region, Alaska: $772-B$, p. B50-B55.

\section{Geochemistry}

Detra, D.E., Detterman, R.L., Cox, D.P., Wilson, F.H., and Theodore, T.G., 1982, Reconnaissance geochemical studies in the Bristol Bay, Ugashik and Karluk quadrangles, Alaska: 844, p. 87-88.

\section{Geochronology}

Wilson, F.H., 1981, K-Ar ages on intrusive rocks and altered zones in the Chignik and Sutwik Island quadrangles: 823-B, p. B45-B46.

Wilson, F.H., Detterman, R.L., and Silberman, M.L., 1978, New ages on intrusive rocks and altered zones on the Alaska Peninsula: 772-B, p. B63-B65.

Wilson, F.H., and Shew, Nora, 1982, Preliminary results of potassium-argon age determinations from the Ugashik quadrangle, Alaska Peninsula: 844, p. 86-87.

\section{Geophysics}

Case, J.E., Cox, D.P., Detra, D.E., Detterman, R.L., and Wilson, F.H., 1982, Aeromagnetic survey of Chignik and Sutwik Island quadrangles: 844, p. 88-89.

Karl, Susan, and Hoare, J.M., 1979, Results of a preliminary paleomagnetic study of volcanic rocks from Nuyakuk Lake, southwestern Alaska: 804-B, P. B74-B78.

\section{Marine geology}

Childs, J.R., Scholl, D.W., and Vallier, Tracy, 1981, Onshore and offshore studies, Amlia Island area, Aleutian Ridge: 823-B, p. B134-B138.

Palmer, I.F., and Lyle, W.M., 1977, Cooperative stratigraphic project in lower Cook Inlet and Kodiak areas, U.S. Geological Survey and State of Alaska Division of Geological and Geophysical Surveys: 751-B, p. B45-B46. 


\section{Metamorphic geology}

Box, S.E., 1985, Geologic setting of high-pressure metamorphic rocks, Cape Newenham area, southwestern Alaska: 967 , p. 37-42.

Hoare, J.M., and Coonrad, W.L., 1977, Blue amphibole occurrences in southwestern Alaska: 751-B, p. B39-B40. 1978, Lawsonite in southwestern Alaska: 772-B, P. B55-B57. 1979, The Kanektok metamorphic complex, a rootless belt of Precambrian rocks in southwestern Alaska: 804-B, P. B72-B74.

\section{Oil and gas}

McLean, Hugh, 1978, Tertiary sedimentary rocks of the Alaska Peninsula between Pavlof Bay and False Pass; their geology and petroleum potential: 772-B, P. B65.

\section{Paleontology}

Detterman, R.L., Case, J.E., and Wilson, F.H., 1979, Paleozoic rocks on the Alaska Peninsula: 804-B, P. B85-B86.

Detterman, R.L., and Miller, J.W., 1986, A widespread catastrophic event in the Naknek Formation, Alaska Peninsula: 978, p. 27-29.

Hoare, J.M., and Coonrad, W.L., 1976, Atomodesma in southwestern Alaska: 733, p. 44. Hoare, J.M., and Jones, D.L., 1981, Lower Paleozoic radiolarian chert and associated rocks in the Tikchik Lakes area, southwestern Alaska: 823-B, P. B44-B45.

Miller, J.W., and Detterman, R.L., 1985, The Buchia zones in upper Jurassic rocks on the Alaska Peninsula: 945, p. 51-53.

Miller, J.W., Detterman, R.L., and Case, J.E., 1982, Lower Cretaceous (Albian) rocks on the Alaska Peninsula: 844, p. 83-86.

Reed, K.M., Blome, C.D., Gilbert, W.G., and Solie, D.N., 1985, Jurassic Radiolaria from the Lime Hills quadrangle: 945 , p. 53-54.

\section{Petrology; petrography}

Egbert, R.M., and Magoon, L.B., 1981, Petrography, provenance, and tectonic significance of Middle and Upper Jurassic sandstone from Tuxedni Bay, Cook Inlet, Alaska: 823-B, p. B86-B88.

Hildreth, Wes, Fierstein, J.E., Grunder, Anita, and Jager, Larry, 1984, The 1912 eruption in the Valley of Ten Thousand Smokes, Katmai National Park-A summary of the stratigraphy and petrology of the ejecta: 868, p. 37-39.

Hoare, J.M., and Coonrad, W.L., 1978, Lawsonite in southwestern Alaska: 772-B, p. B55-B57.

Lankford, S.M., and Magoon, L.B., 1978, Petrography of the Upper Jurassic through 01 igocene sandstones in the Cape Douglas area, lower Cook Inlet: 772-B, p. B60-B62.

Mullen, M.W., 1987, Petrology and provenance of sandstones of the Naknek Formation, Alaska Peninsula: 998 , p. 86-90.

\section{Quaternary geology}

Weber, F.R., 1985, Late Quaternary glaciation of the Pavlof Bay and Port Moller areas, Alaska Peninsula: 967 , p. 42-44.

Yount, M.E., Wilson, F.H., and Miller, J.W., 1985, Newly discovered Holocene volcanic vents, Port Moller and Stepovak Bay quadrangles: 945, p. 60-62. 


\section{Remote sensing}

York, J.E., Wilson, F.H., and Gamble, B.M., 1985, Digital image processing techniques for detecting surface alteration--An application on the Alaska Peninsula: 945 , p. 56-58.

\section{Sedimentary geology}

Allaway, W.H., Jr., and Miller, J.W., 1984, Newly recognized sedimentary environments in the Shelikof Formation: 868, p. 34-37.

Box, S.E., and Murphy, J.M., 1987, Late Mesozoic structural and stratigraphic framework, eastern Bethel quadrangle, southwestern Alaska: 998, p. 78-82.

Decker, J.E., and Hoare, J.M., 1982, Sedimentology of the Cretaceous Kuskokwim Group, southwest Alaska: 844, p. 81-83.

Detterman, R.L., 1978, Interpretation of depositional environments in the Chignik Formation, Alaska Peninsula: 772-B, p. B62-B63.

Detterman, R.L., and Miller, J.W., 1985, Kaguyak Formation--An Upper Cretaceous flysch deposit: 945, p. 49-51.

Egbert, R.M., and Magoon, L.B., 1981, Petrography, provenance, and tectonic significance of Middle and Upper Jurassic sandstone from Tuxedni Bay, Cook Inlet, Alaska: 823-B, p. B86-B88.

Hildreth, Wes, Fierstein, J.E., Grunder, Anita, and Jager, Larry, 1984, The 1912 eruption in the Valley of Ten Thousand Smokes, Katmai National Park--A sumary of the stratigraphy and petrology of the ejecta: 868, p. 37-39.

Lankford, S.M., and Magoon, L.B., 1978, Petrography of the Upper Jurassic through Oligocene sandstones in the Cape Douglas area, lower Cook Inlet: 772-B, P. B60-B62.

Magoon, L.B., Egbert, R.M., and Petering, George, 1978, Upper Jurassic and Cretaceous rocks of the Kamishak Hills-Douglas River area, lower Cook Inlet: 772-B, p. B57-B59.

McLean, Hugh, 1978, Tertiary sedimentary rocks of the Alaska Peninsula between Pavlof Bay and False Pass; their geology and petroleum potential: 772-B, P. B65.

Miller, J.W., Detterman, R.L., and Case, J.E., 1982, Lower Cretaceous (Albian) rocks on the Alaska Peninsula: 844, p. 83-86.

Mullen, M.W., 1987, Petrology and provenance of sandstones of the Naknek Formation, Alaska Peninsula: 998 , p. 86-90.

Murphy, J.M., 1987, Early Cretaceous cessation of terrane accretion, northern Eek Mountains, southwestern Alaska: 998, p. 83-85.

Nilsen, T.H., 1984, Miocene back-arc tidal deposits of the Bear Lake Formation, Alaska Peninsula: 939 , p. 85-88.

\section{Seismicity}

Lisowski, Michael, Savage, J.C., and Prescott, W.H., 1984, Horizontal-strain observations in the Shumagin Island and Yakataga seismic gaps, Alaska: 868, p. 9-10.

\section{Structural geology; tectonics}

Box, S.E., 1985, Terrane analysis of the northern Bristol Bay region, southwestern Alaska: 967, p. 32-37.

Box, S.E., and Murphy, J.M., 1987, Late Mesozoic structural and stratigraphic framework, eastern Bethel quadrangle, southwestern Alaska: 998, p. 78-82. 
Egbert, R.M., and Magoon, L.B., 1981, Petrography, provenance, and tectonic significance of Middle and Upper Jurassic sandstone from Tuxedni Bay, Cook Inlet, Alaska: 823-B, p. B86-B88.

Hoare, J.M., and Coonrad, W.L., 1979, The Kanektok metamorphic complex, a rootless belt of Precambrian rocks in southwestern Alaska: 804-B, P. B72-B74.

Murphy, J.M., 1987, Early Cretaceous cessation of terrane accretion, northern Eek Mountains, southwestern Alaska: 998, p. 83-85.

Nilsen, T.H., 1984, Miocene back-arc tidal deposits of the Bear Lake Formation, Alaska Peninsula: 939, p. 85-88.

Wilson, F.H., Case, J.E., and Detterman, R.L., 1985, Preliminary description of a Miocene zone of structural complexity, Port Moller and Stepovak Bay quadrangles: 945 , p. 55-56.

\section{Volcanoes; volcanic rocks}

Coonrad, W.L., and Hoare, J.M., The Togiak tuya: 733, p. 44-45.

Hildreth, Wes, Fierstein, J.E., Grunder, Anita, and Jager, Larry, 1984, The 1912 eruption in the Valley of Ten Thousand Smokes, Katmai National Park--A summary of the stratigraphy and petrology of the ejecta: 868, p. 37-39.

Johnston, D.A., 1979, Onset of volcanism at Augustine Volcano, lower Cook Inlet: 804-B, P. B 78-B80. 1979, Volcanic gas studies at Alaskan volcanoes: 804-B, p. B83-B84.

Johnston, D.A., and Detterman, R.L., 1979, Revision of the recent eruption history of Augustine Volcano--Elimination of the "1902 eruption": 804-B, p. B80-B83.

Karl, Susan, and Hoare, J.M., 1979, Results of a preliminary paleomagnetic study of volcanic rocks from Nuyakuk Lake, southwestern Alaska: 804-B, P. B74-B78.

Keith, T.E.C., 1984, Preliminary observations on fumarole distribution and al teration, Valley of 10,000 Smokes, Alaska: 939, p. 82-85.

Miller, T.P., and Smith, R.L., 1976, "New" volcanoes in the Aleutian volcanic arc: 733 , p. 11 .

1976, Two caldera-forming eruptions on Umnak Island, eastern Aleutian Islands: 733 , p. 45.

Yount, M.E., Miller, T.P., Emanuel, R.P., and Wilson, F.H., 1985, Eruption in an icefilled caldera, Mount Veniaminof, Alaska Peninsula: 945, p. 58-60.

Yount, M.E., Miller, T.P., and Gamble, B.M., 1987, The 1986 Eruptions of Augustine Volcano, Alaska--Hazards and effects: 998, p. 4-13.

Yount, M.E., Wilson, F.H., and Miller, J.W., 1985, Newly discovered Holocene volcanic vents, Port Moller and Stepovak Bay quadrangles: 945, p. 60-62. 


\section{Southern Alaska}

\section{Coal}

Sanders, R.B., 1976, Summary of geology and coal resources of the Bering River Coal Field: 733 , p. 54 .

Schmoll, H.R., and Yehle, L.A., 1978, Generalized physiography and geology of the Beluga coal field and vicinity, south-central Alaska: 772-B, P. B73-B76.

Scully, D.R., 1976, Hydrologic investigations related to coal resources: 733 , p. 45.

Severson, R.C., and Gough, L.P., 1984, Estimated physiological tolerance ranges for selected elements in soils, Capps coal field: 939, p. 75-78.

Stanley, R.G., 1987, Effects of weathering on petroleum-source evaluation of coals from the Suntrana Formation near Healy, Alaska: 998, p. 99-103.

\section{Economic geology}

Armstrong, A.K., and Mackevett, E.M., Jr., 1976, Relations between Triassic carbonate sabkhas and Kennecott-type copper deposits, Wrangell Mountains: 733, p. 50-51. 1977, Carbonate sedimentation, sabkha facies, diagenesis, and stratigraphy, lower part of the Chitistone Limestone--The Triassic host rock for Kennecotttype copper deposits: 751-B, p. B56.

Dickinson, K.A., 1979, Uraninite in sideritic nodules from Tertiary continental sedimentary rocks in the Healy Creek basin area, central Alaska: 804-B, P. B98-B99.

Evenson, E.B., Stephens, G.C, Neher, F.R., King, H.D., and Detra, D.E., 1984, Mineral exploration and reconnaissance bedrock mapping using active alpine glaciers, Mount Hayes and Healy quadrangles, southern Alaska: 868, p. 94-95.

Gray, J.E., Church, S.E., and Delevaux, M.H., 1986, Lead-isotope results from goldbearing quartz veins from Valdez and Orca Groups, Chugach National Forest: 978 , p. 45-50.

LeHuray, A.P., Church, S.E., and Nokleberg, W.J., 1985, Lead isotopes in sulfide deposits from the Jarvis Creek Glacier and Wrangellia terranes, Mount Hayes quadrangle, eastern Alaska Range: 945, p. 72-73.

Nokleberg, W.J., and Lange, I.M., 1985, Volcanogenic massive sulfide occurrences, Jarvis Creek Glacier terrane, western Mount Hayes quadrangle, eastern Alaska Range: 945 , p. 77-80.

Nokleberg, W.J., Lange, I.M., and Roback, R.C., 1984, Preliminary accretionary terrane model for metallogenesis of the Wrangellia terrane, southern Mount Hayes quadrangle, eastern Alaska Range, Alaska: 939, p. 60-65.

Pickthorn, W.J., 1984, Stable isotope study of quartz veins in the Port Valdez gold district: 939 , p. 67-70.

Pickthorn, W.J., Goldfarb, R.J., O'Leary, R.M., Sutley, S.J., and Weaver, Sarah, 1985, Kayak Island--Analysis of a geochemical anomaly: 945, p. 82-83.

Pickthorn, W.J., and Nelson, S.W., 1984, Preliminary reconnaissance sulfur isotope geochemistry of massive sulfide occurrences in the Prince William Sound district: 939 , p. 70-71.

Pickthorn, W.J., and Silberman, M.L., 1984, Structural relations and fluid-inclusion data for mineralized and nonmineralized quartz veins in the Port Valdez gold district, Valdez quadrangle, southern Alaska: 868 , p. 86-89.

Silberman, M.L., Mathews, Alan, Potter, R.W., and Nissenbaum, Arie, 1977, Stable isotope geochemistry, sulfide mineralogy, and potassium-argon ages of the Kennecott massive sulfide deposits, Alaska: 751-B, p. B56-B58. 
Silberman, M.L., Mitchell, P.A., and O'Neil, J.R., 1981, Isotopic data bearing on the origin and age of the epithermal lode gold deposits in the Hope-Sunrise district, northern Kenai Peninsula, Alaska: 823-B, p. B81-B84.

Silberman, M.L., Morton, J.L., Cox, D.C., and Richter, D.H., 1977, Potassium-argon ages of disseminated copper and molybdenum mineralization in the $\mathrm{Klein}$ Creek and Nabesna plutons, eastern Alaska Range: 751-B, p. B54-B56.

Silberman, M.L., and O'Leary, R.M., 1976, Geochemical anomalies in the Willow Creek mining district, Talkeetna Mountains: 733, p. 48-49.

Silberman, M.L., Potter, R.W., II, and Nissenbaum, Arie, 1976, Stable isotope, sulfide mineralogy, fluid inclusion, and $\mathrm{K}-\mathrm{Ar}$ age study of the massive sulfide deposits at Kennecott: 733, p. 51-52.

Winkler, G.R., Mackevett, E.M., Jr., and Nelson, S.W., 1977, strata-bound ironcopper-zinc sulfide deposits, Prince William Sound region, southern Alaska: 751-B, P. B44-B45.

Yeend, Warren, 1981, Placer gold deposits, Mount Hayes quadangle, Alaska: 823-B, p. B68.

1984, Placers and placer mining in the Healy quadrangle, southern Alaska: 868 , p. 95-98.

\section{General geology}

Albert, N.R.D., 1976, LANDSAT data interpretation, Nabesna and McCarthy quadrangles: 733 , p. 49-50.

Albert, N.R.D., and Steele, W.C., 1977, LANDSAT data interpretation, McCarthy, Tanacross, and Talkeetna quadrangles: 751-B, P. B58-B61.

Brew, D.A., and Morrell, R.P., 1979, Correlation of the Sitka Graywacke, unnamed rocks in the Fairweather Range, and Valdez Group, southeastern and south-central Alaska: 804-B, p. B123-B 125 .

Cowing, D.J., and Emanuel, Richard, 1982, Water resources of the Anchorage area: 844 , p. 117 .

Csejtey, Bela, Jr., 1979, Regional significance of tectonics of the Talkeetna Mountains, south-central Alaska: 804-B, P. B90-B92.

Csejtey, Bela, Jr., and Evarts, R.C., 1979, Serpentinite bodies in the Willow Creek district, southwestern Talkeetna Mountains, Alaska: 804-B, P. B92-B93.

Csejtey, Bela, Jr., and Nelson, W.H., 1979, Trondhjemite in the Talkeetna Mountains, south-central Alaska: 804-B, P. B93-B96.

Dumoulin, J.A., and Miller, M.L., 1984, The Jeanie Point complex revisited: 868, p. $75-77$.

Evenson, E.B., Stephens, G.C., and Detra, D.E., 1985, Bedrock mapping of remote areas using moraine debris from active glaciers, Mt. Hayes and Healy quadrangles: 967 , p. 55-56.

Evenson, E.B., Stephens, G.C., Neher, F.R., King, H.D., and Detra, D.E., 1984, Mineral exploration and reconnaissance bedrock mapping using active alpine glaciers, Mount Hayes and Healy quadrangles, southern Alaska: 868, p. 94-95.

Goldfarb, R.J., 1984, A preliminary geochemical interpretation of the Chugach Wilderness, southern Alaska: 868 , p. 89-92.

Hudson, Travis, 1979, Plutonism and regional geology in southern Alaska: 804-B, p. B86-B88.

Nelson, W.H., Csejtey, Bela, Jr., and Dean, R.M., 1976, Reconnaissance geology of the western Talkeetna Mountains quadrangle: 733, p. 47-48.

Nokleberg, W.J., Zehner, R.E., and Miyaoka, R.T., 1982, Geologic setting of the Maclaren metamorphic belt, Mount Hayes $A-6$ and $B-6$ quadrangles, eastern Alaska Range, Alaska: 844, p. 97-100. 
Plafker, George, Nokleberg, W.J., and Lull, J.S., 1985, Summary of 1984 TACT geologic studies on the northern Chugach Mountains and southern Copper River basin: 967, p. 76-79.

Sanders, R.B., 1976, Sumary of geology and coal resources of the Bering River Coal Field: 733 , p. 54 .

\section{Geochemistry}

Church, S.E., Gray, J.E., and Delevaux, M.H., 1986, Use of Pb-isotopic signatures for geochemical exploration in the Healy quadrangle, eastern Alaska Range: 978, p. $38-41$.

Curtin, G.C., Tripp, R.B., O'Leary, R.M., and Huston, D.L., 1984, Geochemically anomalous areas north of the Denali fault in the Mount Hayes quadrangle, southern Alaska: 868 , p. 92-93.

Dickinson, K.A., 1979, Uraninite in sideritic nodules from Tertiary continental sedimentary rocks in the Healy Creek basin, area, central Alaska: 804-B, P. B98-B99.

Evenson, E.B., Stephens, G.C., Curtin, G.C., and Tripp, R.B., 1982, Geochemical exploration using englacial debris: 844, p. 108-109.

Goldfarb, R.J., 1984, A preliminary geochemical interpretation of the Chugach Wilderness, southern Alaska: 868, p. 89-92.

Goldfarb, R.J., Folger, P.F., Smaglik, S.M., and Tripp, R.B., 1984, A statistical interpretation of geochemical data from Chugach National Forest: 939, p. 47-50.

Gray, J.E., Church, S.E., and Delevaux, M.H., 1986, Lead-isotope results from goldbearing quartz veins from Valdez and Orca Groups, Chugach National Forest: 978, P. 45-50.

Hoffman, J.D., 1987, An application of oblique rotation R-Mode factor analysis in the Mount Hayes quadrangle, Alaska abstract : 998, p. 108.

King, H.D., 1982, Reconnaissance geochemical survey of the Healy quadrangle: 844, p. 107-108.

Light, T.D., 1985, Preliminary interpretation of factor analysis of geochemical data from the Healy quadrangle: 967 , p. 64-66.

Mull, C.G., and Nelson, S.W., 1986, Anomalous thermal maturity data from the Orca Group (Paleocene and Eocene), Katalla-Kayak Island area: 978, p. 50-55.

Pickthorn, W.J., 1984, Stable isotope study of quartz veins in the Port Valdez gold district: 939 , p. 67-70.

Pickthorn, W.J., Goldfarb, R.J., O'Leary, R.M., Sutley, S.J., and Weaver, Sarah, 1985, Kayak Island--Analysis of a geochemical anomaly: 945, p. 82-83.

Pickthorn, W.J., and Nelson, S.W., 1984, Preliminary reconnaissance sulfur isotope geochemistry of massive sulfide occurrences in the Prince William Sound district: 939 , p. $70-71$.

Pickthorn, W.J., and Silberman, M.L., 1984, Structural relations and fluid-inclusion data for mineralized and nonmineralized quartz veins in the Port Valdez gold district, Valdez quadrangle, southern Alaska: 868 , p. 86-89.

Silberman, M.L., Mathews, Alan, Potter, R.W., and Nissenbaum, Arie, 1977, Stable isotope geochemistry, sulfide mineralogy, and potassium-argon ages of the Kennecott massive sulfide deposits, Alaska: 751-B, P. B56-B58.

Silberman, M.L., and O'Leary, R.M., 1976, Geochemical anomalies in the Willow Creek mining district, Talkeetna Mountains: 733, p. 48-49.

Silberman, M.I., Potter, R.W., II, and Nissenbaum, Arie, 1976, Stable isotope, sulfide mineralogy, fluid inclusion, and $K-A r$ age study of the massive sulfide deposits at Kennecott: 733, p. 51-52.

Winkler, G.R., 1976, Reconnaissance geochemistry and tectonics of Gulf of Alaska greenstones: 733 , p. 11 . 
Winkler, G.R., Miller, R.J., Silberman, M.L., Grantz, Arthur, Case, J.E., and Pickthorn, W.J., 1981, Layered gabbroic belt of regional extent in the Valdez quadrangle: 823-B, p. B74-B 76 .

\section{Geochronology}

Aleinikoff, J.N., and Nokleberg, W.J., 1984, Early Proterozoic metavolcanic rocks in the Jarvis Creek Glacier tectonostratigraphic terrane, Mount Hayes C-6 quadrangle, eastern Alaska Range, Alaska: 939, p. 40-44. 1984, Uranium-lead geochronology of a metarhyodacite from the Pingston terrane, Mount Hayes C-6 quadrangle, eastern Alaska Range: 868 , p. 73-75. 1985, Age of Devonian igneous-arc terranes in the northern Mount Hayes quadrangle, eastern Alaska Range: 967 , p. 44-49. 1985, Age of intrusion and metamorphism of a granodiorite in the Lake George terrane, northeastern Mount Hayes quadrangle: 945 , p. 62-65.

Aleinikoff, J.N., Nokleberg, W.J., and Herzon, P.L., 1982, Age of intrusion and metamorphism of the East Susitna batholith, Mount Hayes B-6 quadrangle, eastern Alaska Range, Alaska: 844, P. 100-102.

Brew, D.A., and Morrel1, R.P., 1979, Correlation of the Sitka Graywacke, unnamed rocks in the $F$ airweather Range, and Valdez Group, southeastern and south-central Alaska: $804-B$, P. B123-B 125 .

Church, S.E., Gray, J.E., and Delevaux, M.H., 1986, Use of Pb-isotopic signatures for geochemical exploration in the Healy quadrangle, eastern Alaska Range: 978, P. $38-41$.

Gray, J.E., Church, S.E., and Delevaux, M.H., 1986, Lead-isotope results from goldbearing quartz veins from Valdez and Orca Groups, Chugach National Forest: 978, p. 45-50.

Plafker, George, Keller, Gerta, Nelson, S.W., Dumoul in, J.A., and Miller, M.L., 1985, Summary of data on the age of the Orca Group: 967, p. 74-76.

Silberman, M.L., Csejtey, Bela, Jr., Smith, J.G., Lanphere, M.A., and Wilson, F.H., 1978, New potassium-argon data on the age of mineralization and metamorphism in the Willow Creek mining district, southern Talkeetna Mountains, Alaska: 772-B, p. B65-B69.

Silberman, M.L., MacKevett, E.M., Jr., Connor, C.L., Klock, P.R., and Kalechitz, Georgiana, 1981, K-Ar ages of the Nikolai Greenstone from the McCarthy quadrangle, Alaska--The "docking" of Wrangellia: 823-B, p. B61-B63.

Silberman, M.L., Mathews, Alan, Potter, R.W., and Nissenbaum, Arie, 1977, Stable isotope geochemistry, sulfide mineralogy, and potassium-argon ages of the Kennecott massive sulfide deposits, Alaska: 751-B, p. B56-B58.

Silberman, M.L., Mitchell, P.A., and O'Neil, J.R., 1981, Isotopic data bearing on the origin and age of the epithermal lode gold deposits in the Hope-Sunrise district, northern Kenai Peninsula, Alaska: 823-B, p. B81-B84.

Silberman, M.L., Morton, J.L., Cox, D.C., and Richter, D.H., 1977, Potassium-argon ages of disseminated copper and molybdenum mineralization in the Klein Creek and Nabesna plutons, eastern Alaska Range: 751-B, p. B54-B56.

Silberman, M.L., Potter, R.W., II, and Nissenbaum, Arie, 1976, Stable isotope, sulfide mineralogy, fluid inclusion, and $\mathrm{K}-\mathrm{Ar}$ age study of the massive sulfide deposits at Kennecott: 733, p. 51-52. 


\section{Geophysics}

Barnes, D.F., and Csejtey, Bela, Jr., 1985, Strong magnetic and gravity contrasts across the Talkeetna, Totschunda, and Eureka Creek faults versus the lesser geophysical expression of the Denali fault and its strands--A geological puzzle for TACT program: 945, p. 65-68.

Campbel1, D.L., and Barnes, D.F., 1985, Gravity and magnetic model of a part of the 1984 TACT line, Chugach Mountains and southern Copper River basin: 967, p. 5255 .

Campbel1, D.L., and Nokleberg, W.J., 1984, Magnetic profile across accreted terranes, Mount Hayes quadrangle, eastern Alaska Range, Alaska: 939, p. 44-47. 1985, Magnetic profile across Denali fault, Mount Hayes quadrangle, eastern Alaska Range: 945 , p. 68-72. 1986, Magnetic model of a profile across northern Copper River basin, northeastern Gulkana quadrangle: 978 , p. 35-38.

Fuis, G.S., and Ambos, E.L., 1986, Deep structure of the Contact fault and Prince William terrane--Preliminary results of the 1985 TACT seismic-refraction survey: 978 , p. 41-45.

Fuis, G.S., Ambos, E.L., Mooney, W.D., Page, R.A., and Campbel1, D.L., 1985, Preliminary results of TACT 1984 seismic-refraction survey of southern Alaska: 967 , p. 56-60.

Hillhouse, J.W., and Gromme, Sherman, 1981, Paleolatitude of Triassic basalt in the Clearwater Mountains, south-central Alaska: 823-B, P. B55-B56.

1981 , Paleomagnetic investigation in the Chulitna terrane, south-cental Alaska: 823-B, p. B58-B61. 1984, Paleomagnetic latitude of Paleocene volcanic rocks of the Cantwell Formation, central Alaska: 868, p. 80-82. 1985, Paleomagnetism of sedimentary rocks, Prince William and Yakutat terranes: 967, p. $60-62$.

Hillhouse, J.W., Gromme, Sherman, and Csejtey, Bela, Jr., 1984, Paleomagnetism of Early Tertiary volcanic rocks in the northern Talkeetna Mountains: 939, p. 50-52.

Panuska, B.C., Decker, J.E., and Berg, H.C., 1984, A preliminary paleomagnetic study of the Gravina-Nutzotin belt, southern and southeastern Alaska: 868, p. 117-120.

Plafker, George, Nokleberg, W.J., and Lull, J.S., 1985, Summary of 1984 TACT geologic studies on the northern Chugach Mountains and southern Copper River basin: 967, p. 76-79.

Stanley, W.D., 1986, Magnetotelluric study of a compressed flysch in the Healy and adjacent quadrangles: 978 , p. 78-81.

\section{Geothermal studies}

Mu11, C.G., and Nelson, S.W., 1986, Anomalous thermal maturity data from the Orca Group (Paleocene and Eocene), Katalla-Kayak Island area: 978, p. 50-55.

\section{Bydrology}

Anderson, G.S., 1976, Lake level fluctuations, North Kenai area: 733, p. 54. Bartsch-Winkler, Susan, Emanuel, R.P., and Winkler, G.R., 1985, Reconnaissance hydrology and suspended sediment analysis, Turnagain Arm, upper Cook Inlet: 967 , p. 49-52.

Freethey, Geoffrey, 1979, Sources of water for a confined aquifer at Anchorage: $804-B$, P. B 106 . 
Kachadoorian, Reuben, and Moore, H.J., 1979, Watana and Devils Canyon damsites, Susitna River, Alaska: 804-B, P. B99-B101.

Mayo, L.R., 1977, Glacier research: 751-B, P. B5-B6.

Meier, M.F., Mayo, L.R., Post, Austin, Sikonia, W.G., and Trabant, D.C., 1979, Stability of Columbia Glacier, Alaska: 804-B, p. B106-B107.

Nauman, J.W., Sloan, C.E., and Kernodle, D.R., 1977, Stream relocation and benthic invertebrates in Canyon Slough near Valdez, Alaska: 751-B, p. B46.

Richard, J.K., 1978, Application of remotely sensed data for ground-water analysis near Denali, Alaska: 772-B, P. B78-B79. (Report prepared under contract)

Scully, D.R., 1976, Hydrologic investigations related to coal resources: $733, \mathrm{p} .45$.

Sloan, C.E., 1976, Water-resources investigations of the Valdez-Delta Junction area: 733 , p. 47. 1977, Arctic hydrology studies: 751-B, P. B30-B31.

Trabant, D.C., 1976, Alaska glaciology studies: 733, p. 45-47. 1976, Glaciers along TAPS route: 733 , p. 47.

Zenone, Chester, 1976, Geohydrology of the Anchorage area: 733, p. 52-53. 1977, Urban hydrology studies in the Anchorage area: 751-B, P. B52. 1978, Water resources studies in the Anchorage area: 772-B, p. B81-B82.

\section{Marine geology}

Bartsch-Winkler, Susan, 1986, Channel migration in Turnagain Arm: 978, p. 29-33.

Brouwers, E.M., 1982, Preliminary report on ostracode assemblages from the northeast Gulf of Alaska continental shelf: 844 , p. 151-153.

1984, Paleoenvironmental analysis of the ostracodes in Quaternary sediment from cores taken near Icy Bay, Gulf of Alaska: 868, p. 136-139.

Lins, H.F., Jr., 1978, Analysis of remotely sensed data for use in evaluating the onshore impacts of offshore petroleum development at Kenai, Alaska: 772-B, P. B 76-B 78 .

Mullen, M.W., and Csejtey, Bella, Jr., 1986, Recognition of a Nixon Fork terrane equivalent in the Healy quadrangle: 978, p. 55-60.

Palmer, I.F., and Lyle, W.M., 1977, Cooperative stratigraphic project in lower Cook Inlet and Kodiak areas, and State of Alaska Division of Geological and Geophysical Surveys: 751-B, p. B45-B46.

Stephens, Christopher, 1978, Seismicity near Icy Bay, Alaska, and in the eastern Gulf of Alaska: $772-B$, P. B96-B97.

\section{Metamorphic geology}

Aleinikoff, J.N., and Nokleberg, W.J., 1984, Early Proterozoic metavolcanic rocks in the Jarvis Creek Glacier tectonostratigraphic terrane, Mount Hayes $\mathrm{C}-6$ quadrangle, eastern Alaska Range, Alaska: 939, p. 40-44. 1984, Uranium-lead geochronology of a metarhyodacite from the Pingston terrane, Mount Hayes C-6 quadrangle, eastern Alaska Range: 868, p. 73-75. 1985, Age of intrusion and metamorphism of a granodiorite in the Lake George terrane, northeastern Mount Hayes quadrangle: 945 , p. 62-65.

Aleinikoff, J.N., Nokleberg, W.J., and Herzon, P.L., 1982, Age of intrusion and metamorphism of the East Susitna batholith, Mount Hayes B-6 quadrangle, eastern Alaska Range, Alaska: 844, p. 100-102.

Csejtey, Bela, Jr., and Evarts, R.C., 1979, Serpentinite bodies in the Willow Creek district, southwestern Talkeetna Mountains, Alaska: 804-B, p. B92-B93.

Miller, M.L., Dumoulin, J.A., and Nelson, S.W., 1984, A transect of metamorphic rocks along the Copper River, Cordova, and Valdez quadrangles, Alaska: 939, p. 52-57. 
Nokleberg, W.J., and Aleinikoff, J.N., 1985, Summary of stratigraphy, structure, and metamorphism of Devonian igneous-arc terranes, northeastern Mount Hayes quadrangle, eastern Alaska Range: 967, p. 66-71.

Nokleberg, W.J., Aleinikoff, J.N., and Lange, I.M., 1986, Cretaceous deformation and metamorphism in the northeastern Mount Hayes quadrangle, eastern Alaska Range: 978, p. 64-69.

Nokleberg, W.J., Zehner, R.E., and Miyaoka, R.T., 1982, Geologic setting of the Maclaren metamorphic belt, Mount Hayes $A-6$ and $B-6$ quadrangles, eastern Alaska Range, Alaska: 844, p. 97-100.

Silberman, M.L., Csejtey, Bela, Jr., Smith, J.G., Lanphere, M.A., and Wilson, F.H., 1978, New potassium-argon data on the age of mineralization and metamorphism in the Willow Creek mining district, southern Talkeetna Mountains, Alaska: 772-B, P. B65-B69.

Winkler, G.R., Miller, R.J., and Case, J.E., 1981, Blocks and belts of blueschist and greenschist in the northwestern Valdez quadrangle: 823-B, p. B72-B74.

\section{Oil and gas}

Lins, H.F., Jr., 1978, Analysis of remotely sensed data for use in evaluating the onshore impacts of offshore petroleum development at Kenai, Alaska: 772-B, P. B76-B 78.

Stanley, R.G., 1987, Effects of weathering on petroleum-source evaluation of coals from the Suntrana Formation near Healy, Alaska: 998, p. 99-103.

Stanley, R.G., 1987, Thermal maturity and petroleum-source potential of the Cantwell Formation (Paleocene), Alaska Range: 998, p. 104-107.

Whitney, J.W., and Thurston, D.K., 1981, Geologic constraints for petroleum devlopment of the lower Cook Inlet, Alaska, Outer Continental Shelf lease area: $823-B$, P. B122-B124.

\section{Paleontology}

Armstrong, A.K., Harris, A.G., Reed, B.L., and Carter, Claire, 1977, Paleozoic sedimentary rocks in the northwest part of the Talkeetna quadrangle, Alaska Range, Alaska: 751-B, p. B61-B64.

Blueford, J.R., 1986, New radiolarian data from the Orca Group, Prince William Sound: 978, p. 33-35.

Brouwers, E.M., 1984, Paleoenvironmental analysis of the ostracodes in Quaternary sediment from cores taken near I cy Bay, Gulf of Alaska: 868, p. 136-139.

Churkin, Michael, Jr., Reed, B.L., Carter, Claire, and Winkler, G.R., 1977, Lower Paleozoic graptolitic section in the Terra Cotta Mountains, southern Alaska Range: $751-B$, P. B $37-B 38$.

Csejtey, Bela, Jr., Nelson, W.H., Jones, D.L., and Silberling, N.J., 1978, Tectonic significance of newly discovered lower Paleozoic strata in the upper Chulitna Valley, south-central Alaska: 772-B, P. B69-B70.

Jones, D.L., Silberling, N.J., Wardlaw, Bruce, and Richter, Don, 1981, Revised ages of Paleozoic and Mesozoic rocks in the Talkeetna quadrangle, south-central Alaska: 823-B, P. B46-B49.

Karl, Susan, Decker, John, and Jones, D.L., 1979, Early Cretaceous radiolarians from the McHugh Complex, south-central Alaska: 804-B, p. B88-B90.

McClellan, P.H., and Giovanetti, D.M., 1981, New invertebrate fossils, but still no 1 and vertebrates from nonmarine Tertiary rocks of the Kenai Peninsula: 823-B, p. B84-B86. 
Nelson, S.W., Blome, C.D. Harris, A.G., Reed, K.M., and Wilson, F.H., 1986, Late Paleozoic and Early Jurassic fossil ages from the McHugh Complex: 978, p. $60-64$.

Nelson, S.W., Blome, C.D., and Karl, S.M., 1987, Late Triassic and Early Cretaceous fossil ages from the McHugh complex, southern Alaska: 998, p. 96-98.

Plafker, George, Harris, A.G., and Reed, K.M., 1985, Early Pennsylvanian conodonts from the Strelna Formation, Chitina Valley: 967, p. 71-74.

Plafker, George, Keller, Gerta, Nelson, S.W., Dumoulin, J.A., and Miller, M.L., 1985, Summary of data on the age of the Orca Group: 967, p. 74-76.

Wardlaw, B.R., 1982, Smithian and Spathian (Early Triassic) conodont faunas from the Chulitna terrane, south-central Alaska: 844, p. 106-107.

\section{Petrology; petrography}

Armstrong, A.K., and Mackevett, E.M., Jr., 1976, Relations between Triassic carbonate sabkhas and Kennecott-type copper deposits, Wrangell Mountains: 733, p. 50-51. 1977, Carbonate sedimentation, sabkha facies, diagenesis, and stratigraphy, lower part of the Chitistone Limestone--The Triassic host rock for Kennecotttype copper deposits: 751-B, P. B56.

Csejtey, Bela, Jr., and Nelson, W.H., 1979, Trondhjemite in the Talkeetna Mountains, south-central Alaska: 804-B, p. B93-B96.

Egbert, R.M., 1981, Petrography and provenance of Upper Cretaceous sandstone from Saddle Mountain in the Iniskin-Tuxedni area, lower Cook Inlet, Alaska: 823-B, P. B88-B90.

Lull, J.S., and Plafker, George, 1985, Petrography of sandstone from the Yakutat Group, Malaspina district, southern Alaska: 945, p. 73-77.

Nokleberg, W.J., Schwab, C.E., Miyaoka, R.T., and Buhrmaster, C.L., 1984, Stratigraphy, petrology, and structure of the Pingston terrane, Mount Hayes C-5 and C-6 quadrangles, eastern Alaska Range, Alaska: 868, p. 70-73.

Winkler, G.R., 1978, Framework grain mineralogy and provenance of sandstones from the Arkose Ridge and Chickaloon Formations, Matanuska Valley: 772-B, P. B70-B73.

Winkler, G.R., Miller, R.J., Silberman, M.L., Grantz, Arthur, Case, J.E., and Pickthorn, W.J., 1981, Layered gabbroic belt of regional extent in the Valdez quadrangle: $823-B$, P. B 74-B 76 .

Winkler, G.R., and Plafker, George, 1981, Tectonic implications of framework grain mineralogy of sandstone from the Yakutat Group: 823-B, P. B68-B70.

\section{Quaternary geology}

Ager, T.A., 1982, Quaternary history of vegetation in the north Alaska Range: 844 , p. $109-111$.

Ager, T.A., and Sims, J.D., 1984, Postglacial pollen and tephra records from lakes in the Cook Inlet region, southern Alaska: 868, p. 103-105.

Bartsch-Winkler, Susan, and Schmoll, H.R., 1984, Convoluted beds in late Holocene in tidal sediment at the mouth of Knik Arm, upper Cook Inlet, Alaska: 868, p. 105-108.

1987, Earthquake-caused sedimentary couplets in the Upper Cook Inlet region: 998 , p. 92-95.

Brouwers, E.M., 1984, Paleoenvironmental analysis of the ostracodes in Quaternary sediment from cores taken near Icy Bay, Gulf of Alaska: 868, p. 136-139.

Connor, C.L., 1984, A middle Wisconsin pollen record from the Copper River basin, Alaska: 868, P. 102-103.

Hudson, Travis, Plafker, George, and Rubin, Meyer, 1976, Uplift rates of marine terrace sequences in the Gulf of Alaska: 733, p. 11-13. 
Kachadoorian, Reuben, Ovenshine, A.T., and Bartsch-Winkler, Susan, 1977, Late Wisconsin history of the south shore of Turnagain Arm, Alaska: 751-B, p. B49-B50.

Mayo, L.R., 1977, Glacier research: 751-B, p. B5-B6.

Plafker, George, Hudson, Travis, Rubin, Meyer, and Dixon, K.L., 1982, Holocene marine terraces and uplift history in the Yakataga seismic gap near Icy Cape, Alaska: 844, p. 111-115.

Sims, J.D., and Rymer, M.J., 1977, Study of modern lacustrine and glaciolacustrine sediments for earthquake-induced deformational structures, Kenai Peninsula: 751-B, P. B46-B47.

Williams, J.R., 1986, New radiocarbon dates from the Matanuska Glacier bog section: 978, p. 85-88.

Williams, J.R., and Coulter, H.W., 1981, Deglaciation and sea-level fluctuations in Port Valdez, Alaska: 823-B, p. B $78-B 80$.

\section{Remote sensing}

Albert, N.R.D., 1976, LANDSAT data interpretation, Nabesna and McCarthy quadrangles: 733 , p. 49-50.

Albert, N.R.D., and Steele, W.C., 1977, LANDSAT data interpretation, McCarthy, Tanacross, and Talkeetna quadrangles: 751-B, P. B58-B61.

Lins, H.F., Jr., 1978, Analysis of remotely sensed data for use in evaluating the onshore impacts of offshore petroleum development at Kenai, Alaska: 772-B, p. B76-B78.

Richard, J.K., 1978, Application of remotely sensed data for ground-water analysis near Denali, Alaska: 772-B, p. B78-B79. (Report prepared under contract)

Rohde, W.G., Miller, W.A., and Nelson, C.A., 1978, Classification of vegetation in the Denali, Alaska area with digital Landsat data: 772-B, p. B80-B81. (Report prepared under contract)

Sheehan, C.A., 1978, Computer enhancement of Landsat digital data for mapping material-related geomorphic features near Denali, Alaska: 772-B, p. B79-B80. (Report prepared under contract)

Stanley, W.D., 1986, Magnetotelluric study of a compressed flysch in the Healy and adjacent quadrangles: 978 , p. 78-81.

\section{Sedimentary geology}

Armstrong, A.K., Harris, A.G., Reed, B.L., and Carter, Claire, 1977, Paleozoic sedimentary rocks in the northwest part of the Talkeetna quadrangle, Alaska Range, Alaska: 751-B, p. B61-B64.

Armstrong, A.K., and MacKevett, E.M., Jr., 1976, Relations between Triassic carbonate sabkhas and Kennecott-type copper deposits, Wrangell Mountains: 733, p. 50-51. 1977, Carbonate sedimentation, sabkha facies, diagenesis, and stratigraphy, lower part of the Chitistone Limestone-The Triassic host rock for Kennecotttype copper deposits: 751-B, p. B56.

Bartsch-Winkler, Susan, 1986, Channel migration in Turnagain Arm: 978, p. 29-33.

Bartsch-Winkler, Susan, and Garrow, H.C., 1982, Depositional system approaching maturity at Portage Flats: 844 , p. 115-117.

Bartsch-Winkler, Susan, and Schmoll, H.R., 1984, Convoluted beds in late Holocene intertidal sediment at the mouth of Knik Arm, upper Cook Inlet, Alaska: 868, p. $105-108$.

1987, Earthquake-caused sedimentary couplets in the Upper Cook Inlet region: 998, p. 92-95. 
Brew, D.A., and Morrel1, R.P., 1979, Correlation of the Sitka Graywacke, unnamed rocks in the Fairweather Range, and Valdez Group, southeastern and south-central Alaska: 804-B, p. B123-B125.

Egbert, R.M., 1981, Petrography and provenance of Upper Cretaceous sandstone from Saddle Mountain in the Iniskin-Tuxedni area, lower Cook Inlet, Alaska: 823-B, p. B88-B90.

Kachadoorian, Reuben, Ovenshine, A.T., and Bartsch-Winkler, Susan, 1977, Late Wisconsin history of the south shore of Turnagain Arm, Alaska: 751-B, P. B49-B50.

Lull, J.S., and Plafker, George, 1985, Petrography of sandstone from the Yakutat Group, Malaspina district, southern Alaska: 945, p. 73-77.

McClellan, P.H., and Giovanetti, D.M., 1981, New invertebrate fossils, but still no land vertebrates from nonmarine Tertiary rocks of the Kenai Peninsula: 823-B, p. B84-B86.

Mullen, M.W., and Csejtey, Bkla, Jr., 1986, Recognition of a Nixon Fork terrane equivalent in the Healy quadrangle: 978 , p. 55-60.

Nelson, S.W., Blome, C.D., and Karl, S.M., 1987, Late Triassic and Early Cretaceous fossil ages from the McHugh complex, southern Alaska: 998, p. 96-98.

Nilsen, T.H., Plafker, George, Atwood, D.E., and Hill, E.R., 1984, Sedimentology of flysch of the upper Mesozoic Yakutat Group, Malaspina district, Alaska: 939, p. 57-60.

Nokleberg, W.J., Albert, N.R.D., Herzon, P.L., Miyaoka, R.T., and Zehner, R.E., 1981, Recognition of two subterranes within the Wrangellia terrane, southern Mount Hayes quadrangle, Alaska: 823-B, p. B64-B66.

Nokleberg, W.J., and Aleinikoff, J.N., 1985, Summary of stratigraphy, structure, and metamorphism of Devonian igneous-arc terranes, northeastern Mount Hayes quadrangle, eastern Alaska Range: 967, p. 66-71.

Nokleberg, W.J., Schwab, C.E., Miyaoka, R.T., and Buhrmaster, C.L., 1984, Stratigraphy, petrology, and structure of the Pingston terrane, Mount Hayes C-5 and C-6 quadrangles, eastern Alaska Range, Alaska: 868, p. 70-73.

Ovenshine, A.T., Bartsch-Winkler, Susan, Rupert, Jeff, and Kachadoorian, Reuben, 1977, Preliminary studies of a 93-m core at Portage, Alaska: 751-B, P. B50-B51.

Plafker, George, Harris, A.G., and Reed, K.M., 1985, Early Pennsylvanian conodonts from the Strelna Formation, Chitina Valley: 967, p. 71-74.

Plafker, George, Richter, D.H., and Hudson, Travis, 1977, Reinterpretation of the origin of inferred Tertiary tillite in the northern Wrangell Mountains, Alaska: $751-B$, p. B52-B54.

Sims, J.D., and Rymer, M.J., 1977, Study of modern lacustrine and glaciolacustrine sediments for earthquake-induced deformational structures, Kenai Peninsula: $751-B$, P. B46-B47.

Stanley, R.G., 1987, Effects of weathering on petroleum-source evaluation of coals from the Suntrana Formation near Healy, Alaska: 998, p. 99-103.

Stanley, R.G., 1987, Thermal maturity and petroleum-source potential of the Cantwell Formation ( $P$ al eocene), Alaska Range: 998, p. 104-107.

Williams, J.R., 1986, New radiocarbon dates from the Matanuska Glacier bog section: 978 , p. 85-88.

Winkler, G.R., 1978, Framework grain mineralogy and provenance of sandstones from the Arkose Ridge and Chickaloon Formations, Matanuska Valley: 772-B, p. B70-B73.

Winkler, G.R., and Plafker, George, 1981, Tectonic implications of framework grain mineralogy of sandstone from the Yakutat Group: 823-B, P. B68-B70.

Winkler, G.R., and Tysdal, R.G., 1977, Conglomerate in flysch of the Orca Group, Prince William Sound, southern Alaska: 751-B, P. B43-B44. 


\section{Seismicity}

Bartsch-Winkler, Susan, and Schmol1, H.R., 1987, Earthquake-caused sedimentary couplets in the Upper Cook Inlet region: 998, p. 92-95.

Blackford, Michael, 1977, Seismicity patterns in the Cook Inlet, Prince William Sound region, Alaska: 751-B, P. B94-B 96 .

Lahr, J.C., and Blackford, Michael, 1976, Gulf of Alaska seismicity: 733, p. 55.

Lahr, J.C., Page, R.A., Fogleman, K.A., and Stephens, C.D., 1985, New evidence for activity on the Talkeetna segment, Castle Mountain-Caribou fault system--The 1984 Sutton earthquake: 967 , p. 62-63.

Lisowski, Michael, Savage, J.C., and Prescott, W.H., 1984, Horizontal-strain observations in the Shumagin Island and Yakataga seismic gaps, Alaska: 868, P. $9-10$.

Page, R.A., Hassler, M.H., Stephens, C.D., and Criley, E.E., 1984, Fault zone geometry of the 1979 St. Elias, Alaska earthquake: 939, p. 65-67.

Page, R.A., Stephens, C.D., Fogleman, K.A., and Maley, R.P., 1985, The Columbia Bay earthquakes of 1983: 945 , p. 80-82.

Plafker, George, Hudson, Travis, Rubin, Meyer, and Dixon, K.L., 1982, Holocene marine terraces and uplift history in the Yakataga seismic gap near Icy Cape, Alaska: 844, P. $111-115$.

Sims, J.D., and Rymer, M.J., 1977, Study of modern lacustrine and glaciolacustrine sediments for earthquake-induced deformational structures, Kenai Peninsula: 751-B, p. B46-B47.

Stephens, C.D., 1978, Seismicity near Icy Bay, Alaska, and in the eastern Gulf of Alaska: 772-B, p. B96-B97.

Stephens, C.D., Fogleman, K.A., Lahr, J.C., and Page, R.A., 1985, Seismicity in southern Alaska, October 1983-September 1984: 967, p. 79-82. 1986, Seismicity in southern Alaska, October 1984-September 1985: 978, p. $81-85$.

Stephens, C.D., Fogleman, K.A., Page, R.A., and Lahr, J.C., 1985, Seismicity in southern Alaska, October 1982-September 1983: 945, p. 83-86.

Stephens, C.D., and Lahr, J.C., 1979, Seismicity in southern and southeastern Alaska: 804-B, p. B 104-B 106. 1982, Seismic studies in southern and southeastern Alaska: 844, p. 89-93.

Stephens, C.D., Lahr, J.C., and Page, R.A., 1984, Seismic studies in southern Alaska: 868 , p. 7-9. 1984, Seismicity along southern coastal Alaska--October 1981-September 1982: 939, p. 78-82.

\section{Structural geology; tectonics}

Albert, N.R.D., and Steele, W.C., 1979, Clay model showing deformation of the Wrangell Mountains along gravity-correlative Landsat lineaments in the McCarthy quadrangle, Alaska: 804-B, P. B101-B102.

Aleinikoff, J.N., and Nokleberg, W.J., 1984, Early Proterozoic metavolcanic rocks in the Jarvis Creek Glacier tectonostratigraphic terrane, Mount Hayes C-6 quadrangle, eastern Alaska Range, Alaska: 939, p. 40-44. 1985, Age of Devonian igneous-arc terranes in the northern Mount Hayes quadrangle, eastern Alaska Range: 967, p. 44-49.

Barnes, D.F., and Csejtey, Bela, Jr., 1985, Strong magnetic and gravity contrasts across the Talkeetna, Totschunda, and Eureka Creek faults versus the lesser geophysical expression of the Denali fault and its strands--A geological puzzle for TACT program: 945, p. 65-68. 
Brew, D.A., and Morrel1, R.P., 1979, Correlation of the Sitka Graywacke, unnamed rocks in the Fairweather Range, and Valdez Group, southeastern and south-central Alaska: $804-B$, p. B123-B 125 .

Campbell, D.L., and Barnes, D.F., 1985, Gravity and magnetic model of a part of the 1984 TACT line, Chugach Mountains and southern Copper River basin: 967, P. 52-55.

Campbe11, D.L., and Nokleberg, W.J., 1984, Magnetic profile across accreted terranes, Mount Hayes quadrangle, eastern Alaska Range, Alaska: 939, p. 44-47. 1985, Magnetic profile across Denali fault, Mount Hayes quadrangle, eastern Alaska Range: 945 , p. 68-72. 1986, Magnetic model of a profile across northern Copper River basin, northeastern Gulkana quadrangle: 978, p. 35-38.

Coney, P.J., Silberling, N.J., Jones, D.L., and Richter, D.H., 1981, Structural relations along the leading edge of the Wrangellia terrane in the Clearwater Mountains, Alaska: 823-B, P. B56-B58.

Csejtey, Bela, Jr., 1979, Regional significance of tectonics of the Talkeetna Mountains, south-central Alaska: 804-B, P. B90-B92. 1979 , Serpentinite bodies in the Willow Creek district, southwestern Talkeetna Mountains, Alaska: 804-B, P. B92-B93.

Csejtey, Bela, Jr., Cox, D.P., Evarts, R.C., Stricker, G.D., and Mullen, M.W., 1982, The Denali fault system of Alaska--The case for minor rather than major Cenozoic lateral displacement: 844, p. 102-106.

Csejtey, Bella, Jr., Nelson, W.H., Jones, D.L., and Silberling, N.J., 1978, Tectonic significance of newly discovered lower Paleozoic strata in the upper Chulitna Valley, south-central Alaska: 772-B, p. B69-B70.

Csejtey, Bella, Jr., and St. Aubin, Dennis, 1981, Evidence for northwestward thrusting of the Talkeetna superterrane and its regional significance: 823-B, P. B49-B51.

Csejtey, Bela, Jr., Yeend, W.E., and Goerz, D.J., III, 1984, Occurrence of the Cantwell(?) Formation south of the Denali fault system in the Healy quadrangle, southern Alaska: 868, p. 77-79.

Dumoulin, J.A., and Miller, M.L., 1984, The Jeanie Point complex revisited: 868, p. $75-77$.

Fuis, G.S., and Ambos, E.L., 1986, Deep structure of the Contact fault and Prince William terrane--preliminary results of the 1985 TACT seismic-refraction survey: 978 , p. 41-45.

Fuis, G.S., Ambos, E.L., Mooney, W.D., Page, R.A., and Campbe11, D.L., 1985, Preliminary results of TACT 1984 seismic-refraction survey of southern Alaska: 967 , p. 56-60.

Grome, Sherman, and Hillhouse, J.W., 1981, Paleomagnetic evidence for northward movement of the Chugach terrane, southern and southeastern Alaska: 823-B, P. B 70-B 72 .

Hudson, Travis, Plafker, George, and Rubin, Meyer, 1976, Uplift rates of marine terrace sequences in the Gulf of Alaska: 733, p. 11-13.

Hudson, Travis, and Weber, F.R, 1977, The Donnelly Dome and Granite Mountain faults, south-central Alaska: 751-B, P. B64-B66.

LeHuray, A.P., Church, S.E., and Nokleberg, W.J., 1985, Lead isotopes in sulfide deposits from the Jarvis Creek Glacier and Wrangellia terranes, Mount Hayes quadrangle, eastern Alaska Range: 945, p. 72-73.

Mullen, M.W., and Csejtey, Bela, Jr., 1986, Recognition of a Nixon Fork terrane equivalent in the Healy quadrangle: 978, p. 55-60.

Nilsen, T.H., 1982, Accretion model for the Cretaceous Chugach terrane, southern Alaska: 844 , p. 93-97. 
Nokleberg, W.J., Albert, N.R.D., Herzon, P.L., Miyaoka, R.T., and Zehner, R.E., 1981, Cross section showing accreted Andean-type arc and island arc terranes in southwestern Mount Hayes quadrangle, Alaska: 823-B, P. B66-B67.

1981, Recognition of two subterranes within the Wrangellia terrane, southern Mount Hayes quadrangle, Alaska: 823-B, P. B64-B66.

Nokleberg, W.J., Albert, N.R.D., and Zehner, R.E., 1979, The ophiolite of Tangle Lakes in the southern Mount Hayes quadrangle, eastern Alaska Range--An accreted terrane?: 804-B, P. B96-B98.

Nokleberg, W.J., and Aleinikoff, J.N., 1985, Summary of stratigraphy, structure, and metamorphism of Devonian igneous-arc terranes, northeastern Mount Hayes quadrangle, eastern Alaska Range: 967, p. 66-71.

Nokleberg, W.J., Aleinikoff, J.N., and Lange, I.M., 1986, Cretaceous deformation and metamorphism in the northeastern Mount Hayes quadrangle, eastern Alaska Range: 978 , p. 64-69.

Nokleberg, W.J., and Lange, I.M., 1985, Volcanogenic massive sulfide occurrences, Jarvis Creek Glacier terrane, western Mount Hayes quadrangle, eastern Alaska Range: 945 , p. 77-80.

Nokleberg, W.J., Lange, I.M., and Roback, R.C., 1984, Preliminary accretionary terrane model for metallogenesis of the Wrangellia terrane, southern Mount Hayes quadrangle, eastern Alaska Range, Alaska: 939, p. 60-65.

Nokleberg, W.J., Schwab, C.E., Miyaoka, R.T., and Buhrmaster, C.L., 1984, Stratigraphy, petrology, and structure of the Pingston terrane, Mount Hayes C-5 and C-6 quadrangles, eastern Alaska Range, Alaska: 868, p. 70-73.

Nokleberg, W.J., Wade, W.M., Lange, I.M., and Plafker, George, 1986, Summary of the geology of the Peninsular Terrane, metamorphic complex of Gulkana River, and Wrangellia Terrane, north-central and northwestern Gulkana quadrangle: 978, p. 69-74.

Nokleberg, W.J., Zehner, R.E., and Miyaoka, R.T., 1982, Geologic setting of the Maclaren metamorphic belt, Mount Hayes $A-6$ and $B-6$ quadrangles, eastern Alaska Range, Alaska: 844, p. 97-100.

Pickthorn, W.J., and Silberman, M.L., 1984, Structural relations and fluid-inclusion data for mineralized and nonmineralized quartz veins in the Port Valdez gold district, Valdez quadrangle, southern Alaska: 868 , p. 86-89.

Plafker, George, and Campbell, R.B., 1979, The Border Ranges fault in the Saint Elias Mountains: $804-B$, P. B102-B 104.

Plafker, George, Hudson, Travis, and Richter, D.H., 1977, Preliminary observations on late Cenozoic displacements along the Totschunda and Denali fault systems: 751-B, P. B67-B69.

Plafker, George, Hudson, Travis, Rubin, Meyer, and Dixon, K.L., 1982, Holocene marine terraces and uplift history in the Yakataga seismic gap near Icy Cape, Alaska: 844, P. 111-115.

Plafker, George, Jones, D.L., Hudson, Travis, and Berg, H.C., 1976, The Border Ranges fault system in the Saint Elias Mountains and Alexander Archipelago: 733, p. 14-16.

Plafker, George, Jones, D.L., and Pessagno, E.A., Jr., 1977, A Cretaceous accretionary flysch and melange terrane along the Gulf of Alaska margin: 751-B, p. B41-B43.

Plafker, George, Nokleberg, W.J., and Lul1, J.S., 1985, Summary of 1984 TACT geologic studies on the northern Chugach Mountains and southern Copper River basin: 967, p. 76-79.

Plafker, George, Nokleberg, W.J., Lull, J.S., Roeske, S.M., and Winkler, G.R., 1986, Nature and timing of deformation along the Contact fault system in the Cordova, Bering Glacier, and Valdez quadrangles: 978, p. 74-77. 
Silberling, N.J., Richter, D.H., and Jones, D.L., 1981, Recognition of the Wrangellia terrane in the Clearwater Mountains and vicinity, south-central Alaska: 823-B, p. B51-B55.

Silberman, M.L., and Grantz, Arthur, 1984, Paleogene volcanic rocks of the Matanuska Valley area and the displacement history of the Castle Mountain fault: 868, p. $82-86$.

Silberman, M.L., Mackevett, E.M., Jr., Connor, C.L., Klock, P.R., and Kalechitz, Georgiana, 1981, K-Ar ages of the Nikolai Greenstone from the McCarthy quadrangle, Alaska--The "docking" of Wrangellia: 823-B, P. B61-B63.

Stanley, W.D., 1986, Magnetotelluric study of a compressed flysch in the Healy and adjacent quadrangles: 978 , p. 78-81.

Tysdal, R.G., and Case, J.E., 1977, The McHugh Complex in the Seward quadrangle, south-central Alaska: 751-B, p. B48-B49. 1977, Placer River fault, Seward and Blying Sound quadrangles: 751-B, p. B47-B48.

Weber, F.R., and Turner, D.L., 1977, A late Tertiary thrust fault in the central Alaska Range: 751-B, P. B66-B67.

Winkler, G.R., 1976, Reconnaissance geochemistry and tectonics of Gulf of Alaska greenstones: 733 , p. 11 .

Winkler, G.R., Miller, R.J., and Case, J.E., 1981, Blocks and belts of blueschist and greenschist in the northwestern Valdez quadrangle: 823-B, P. B72-B74.

Winkler, G.R., Miller, R.J., Silberman, M.L., Grantz, Arthur, Case, J.E., and Pickthorn, W.J., 1981, Layered gabbroic belt of regional extent in the Valdez quadrangle: $823-B$, P. $B 74-B 76$.

Winkler, G.R., and Plafker, George, 1981, Tectonic implications of framework grain mineralogy of sandstone from the Yakutat Group: 823-B, p. B68-B 70 .

\section{Surficial geology}

Dobrovolny, Ernest, and Schmoll, H.R., 1976, Engineering geology of the Greater Anchorage Area Borough: 733, p. 52.

Kachadoorian, Reuben, and Moore, H.J., 1979, Watana and Devils Canyon damsites, Susitna River, Alaska: 804-B, P. B99-B101.

Kachadoorian, Reuben, and Ovenshine, A.T., 1984, Natural restoration from the effects of the 1964 earthquake at Portage, southern Alaska: 868, p. 109-110.

Ovenshine, A.T., and Kachadoorian, Reuben, 1976, Estimate of time required for natural restoration of the effects of the 1964 earthquake at Portage: 733, p. 53-54.

Schmoll, H.R., 1977, Engineering geology of Anchorage Borough: 751-B, P. B51-B52.

Schmol1, H.R., and Yehle, L.A., 1978, Generalized physiography and geology of the Beluga coal field and vicinity, south-central Alaska: 772-B, P. B73-B76.

Sheehan, C.A., 1978, Computer enhancement of Landsat digital data for mapping material-related geomorphic features near Denali, Alaska: 772-B, p. B79-B80. (Report prepared under contract)

Whitney, J.W., and Thurston, D.K., 1981, Geologic constraints for petroleum devlopment of the lower Cook Inlet, Alaska, Outer Continental Shelf lease area: 823-B, P. B122-B 124 .

Williams, J.R., and Johnson, K.M., 1981, Surficial deposits of the Valdez quadrangle, Alaska: $823-B$, P. B76-B 78 .

Yehle, L.A., 1976, Reconnaissance engineering geology and geological hazards of the Yakutat area: 733 , p. 54. 


\section{Volcanoes; volcanic rocks}

Hillhouse, J.W., and Gromme, Sherman, 1984, Paleomagnetic latitude of Paleocene volcanic rocks of the Cantwell Formation, central Alaska: 868, p. 80-82.

Hillhouse, J.W., Gromme, Sherman, and Csejtey, Bela, Jr., 1984, Paleomagnetism of Early Tertiary volcanic rocks in the northern Talkeetna Mountains: 939 , p. 50-52.

Miller, T.P., and Smith, R.L., 1976, Ash flows associated with Wrangell Volcano: 733, p. 52.

Richter, D.H., Smith, J.G., Ratte, J.C., and Leeman, W.P., 1984, Shield volcanoes in the Wrangell Mountains: 939, p. 71-75.

Silberman, M.L., and Grantz, Arthur, 1984, Paleogene volcanic rocks of the Matanuska Valley area and the displacement history of the Castle Mountain fault: 868, p. $82-86$. 


\section{Southeastern Alaska}

\section{Economic geology}

Balding, G.0., 1979, Surface-water data from molybdenum resource area, Keta River basin: $804-B$, P. B131-B 132 .

Barton, C.C., and Light, T.D., 1987, Structural fabric analysis of the Perseverance Slate and gold-bearing quartz veins in the south ore body of the Alaska-Juneau lode system, southeastern Alaska: 998, p. 110-112.

Berg, H.C., 1979, Significance of geotectonics in the metallogenesis and resource appraisal of southeastern Alaska--A progress report: 804-B, P. B116. 1981, Upper Triassic volcanogenic massive-sulfide metallogenic province identified in southeastern Alaska: 823-B, P. B104-B108.

Berg, H.C., Elliott, R.L., and Koch, R.D., 1976, Progress report on geology and mineral resources of the Ketchikan quadrangle: 733, p. 62-65.

Brew, D.A., Grybeck, Donald, and Johnson, B.R., 1979, Summary of mineral resources, Glacier Bay National Monument Wilderness Study Area, southeastern Alaska: 804-B, P. B112-B 114 .

Brew, D.A., Grybeck, Donald, Johnson, B.R., and Nutt, C.J., 1976, Glacier Bay National Monument mineral-resource studies recommended: 733, p. 58-59.

Brew, D.A., Himelberg, G.R., Ford, A.B., and Jachens, R.C., 1987, U1tramafic and mafic sills in the vicinity of the Treadwell gold deposits, Douglas Island, southeastern Alaska: 998, p. 119-123.

Erdman, J.A., and Motooka, J.M., 1985, Biogeochemical response at the Greens Creek massive sulfide deposit, Admiralty Island: 945, p. 88-91.

Filipek, L.H., 1984, The possible siginificance of diagenetic remobilization of ore elements in the mud-flat estuarine environment: 939, p. 96-100.

Filipek, L.H., Botinelly, Theodore, and Ficklin, W.H., 1985, Lack of relation between the tidal-flat environment and upstream mineralization, Petersburg quadrangle: 945, P. 92-95.

Ford, A.B., and Brew, D.A., 1978, Minor-metal content of Cretaceous greenstone near Juneau, Alaska: 772-B, P. B85-B88.

1987, The Wright Glacier volcanic plug and dike swarm, southeastern Alaska: 998 , p. 116-118.

Goldfarb, R.J., Light, T.D., and Leach, D.L., 1986, Nature of the ore fluids at the Alaska-Juneau gold deposit: 978, p. 92-95.

Grybeck, Donald, and Brew, D.A., 1979, Mineral resource evaluation method used in Glacier Bay National Monument Wilderness Study Area, southeastern Alaska: 804-B, P. B110-B112.

Hudson, Travis, Elliott, R.L., and Smith, J.G., 1977, Investigations of the Wilson Arm molybdenite deposit: 751-B, p. B74. 1978, Chemistry of Quartz Hills intrusive rocks, Ketchikan quadrangle: 772-B, P. B83-B85.

Koch, R.D., Brew, D.A., and Ford, A.B., 1987, Newly discovered molybdenite occurrence near Boundary Creek, Coast Mountains, southeastern Alaska: 998, p. 124-125.

LeHuray, A.P., Stowel1, H.S., and Church, S.E., 1985, Lead isotopes from volcanogenic massive sulfide deposits in the Alexander terrane: 945, p. 95-96.

Loney, R.A., Himmelberg, G.R., and Shew, Nora, 1987, Salt Chuck palladium-bearing ul tramafic body, Prince of Wales Island: 998, p. 126-127.

Newberry, R.J., and Brew, D.A., 1987, The Alaska-Juneau gold deposit--Remobilized syngenetic versus exotic epigenetic origin: 998, p. 128-131.

Sonnevil, R.A., 1981, New data concerning the geology of the North Bradfield River iron prospects, southeastern Alaska: 823-B, P. B117-B118. 
Staatz, M.H., 1977, I and L vein system, Bokan Mountain, Prince of Wales Island: 751-B, P. B 74-B 75 .

\section{General geology}

Berg, H.C., Elliott, R.L., and Koch, R.D., 1976, Progress report on geology and mineral resources of the Ketchikan quadrangle: 733, p. 62-65.

Berg, H.C., Elliott, R.L., Smith, J.G., and Koch, R.D., 1978, New geological map of Ketchikan and Prince Rupert quadrangles, southeastern Alaska: 772-B, p. B82-B83.

Brew, D.A., 1987, Cenozoic magmatism in southeastern Alaska abstract : 998, p. 137. Brew, D.A., Berg, H.C., Morrell, R.P., Sonnevil, R.A., Hunt, S.J., and Huie, Carl, 1979, The Tertiary Kuiu-Etolin volcanic-plutonic belt, southeastern Alaska: 804-B, P. B129-B 130 .

Brew, D.A., and Ford, A.B., 1977, Coast Range megalineament and Clarence Strait lineament on west edge of Coast Range batholithic complex, southeastern Alaska: 751-B, p. B79. 1987, The Meade Glacier Fault--An important tectonic boundary in the Northern Cordillera, southeastern Alaska: 998, p. 113-115.

Brew, D.A., Ford, A.B., and Garwin, S.L., 1985, Fossiliferous Middle and (or) Upper Triassic rocks within the Coast plutonic-metamorphic complex southeast of Skagway: 967 , p. 86-89.

Brew, D.A., Himmelberg, G.R., Ford, A.B., and Jachens, R.C., 1987, Ultramafic and mafic sills in the vicinity of the Treadwell gold deposits, Douglas Island, southeastern Alaska: 998, p. 119-123.

Brew, D.A., Johnson, B.R., Ford, A.B., and Morrel1, R.P., 1978, Intrusive rocks in the Fairweather Range, Glacier Bay National Monument: 772-B, P. B88-B90.

Brew, D.A., Johnson, B.R., Nutt, C.J., Grybeck, Donald, and Ford, A.B., 1977, Newly discovered granitic and gabbroic bodies in the Fairweather Range, Glacier Bay National Monument, Alaska: 751-B, P. B90-B91.

Brew, D.A., Loney, R.A., Kistler, R.W., Czamanske, G.K., Gromme, C.S., and Tatsumoto, Mitsunobu, 1977, Probable Precambrian or lower Paleozoic rocks in the Fairweather Range, Glacier Bay National Monument, Alaska: 751-B, P. B91-B93.

Brew, D.A., and Morrel1, R.P., 1979, Correlation of the Sitka Graywacke, unnamed rocks in the Fairweather Range, and Valdez Group, southeastern and south-central Alaska: 804-B, P. B123-B125.

1979, Intrusive rock belts of southeastern Alaska: 804-B, P. B116-B121.

Burrel1, P.D., 1984, Cretaceous plutonic rocks, Mitkof and Kupreanof Islands, Petersburg quadrangle, southeastern Alaska: 868, p. 124-126. 1984, Late Cretaceous plutonic rocks, Petersburg quadrangle, southeast Alaska: 939, p. 93-96.

Churkin, Michael, Jr., and Eberlein, G.D., 1977, Correlation of the rocks of southeastern Alaska with other parts of the Cordillera: 751-B, P. B69-B72.

Eberlein, G.D., and Churkin, Michael, Jr., 1976, Progress report on geologic investigations in the Craig quadrangle: 733, p. 61-62.

Ford, A.B., and Brew, D.A., 1987, The Wright Glacier volcanic plug and dike swarm, southeastern Alaska: 998, p. 116-118.

Gehrels, G.E., Saleeby, J.B., and Berg, H.C., 1984, Geologic framework of Paleozoic rocks on southern Annette and Hotspur Islands, southern Alexander terrane: 868, p. $113-115$. 1984, Progress in geologic studies of southern Prince of Wales Island, southern Alexander terrane, southeastern Alaska: 939, p. 102-105. 
Grybeck, Donald, Brew, D.A., Johnson, B.R., and Nutt, C.J., 1977, Ultramafic rocks in part of the Coast Range batholithic complex, southeastern Alaska: 751-B, p. B82-B85.

Hudson, Travis, Dixon, Kirk, and Plafker, George, 1982, Regional uplift in southeastern Alaska: 844, p. 132-135.

Koch, R.D., Brew, D.A., and Ford, A.B., 1987, Newly discovered molybdenite occurrence near Boundary Creek, Coast Mountains, southeastern Alaska: 998, p. 124-125.

LeCompte, J.R., and Steele, W.C., 1981, Landsat data interpretation in the southcentral Brooks Range and in southeastern Alaska: 823-B, P. B1-B3.

Mankinen, E.A., and Plafker, George, 1987, Paleomagnetic evidence for a latest Pliocene and early Pleistocene age of the upper Yakataga Formation on Middleton Island, Alaska: 998 , p. 132-136.

Newberry, R.J., and Brew, D.A., 1987, The Alaska-Juneau gold deposit--Remobilized syngenetic versus exotic epigenetic origin: 998, p. 128-131.

Sonnevil, R.A., 1981, The Chilkat-Prince of Wales plutonic province, southeastern Alaska: $823-B$, P. B112-B 115 . 1981 , New data concerning the geology of the North Bradfield River iron prospects, southeastern Alaska: 823-B, p. B117-B118.

\section{Geochemistry}

Brew, D.A., and Ford, A.B., 1981, The Coast plutonic complex sill, southeastern Alaska: 823-B, P. B96-B99.

Brew, D.A., Johnson, B.R., Ford, A.B., and Morrel1, R.P., 1978, Intrusive rocks in the Fairweather Range, Glacier Bay National Monument: 772-B, p. B88-B90.

Erdman, J.A., and Motooka, J.M., 1985, Biogeochemical response at the Greens Creek massive sulfide deposit, Admiralty Island: 945, p. 88-91.

Filipek, L.H., 1984, The possible siginificance of diagenetic remobilization of ore elements in the mud-flat estuarine environment: 939, p. 96-100.

Filipek, L.H., Botinelly, Theodore, and Ficklin, W.H., 1985, Lack of relation between the tidal-flat environment and upstream mineralization, Petersburg quadrangle: 945, p. 92-95.

Ford, A.B., and Brew, D.A., 1977, Chemical nature of Cretaceous greenstone near Juneau, Alaska: 751-B, p. B88-B90. 1978, Minor-metal content of Cretaceous greenstone near Juneau, Alaska: 772-B, p. B85-B88.

Goldfarb, R.J., Light, T.D., and Leach, D.L., 1986, Nature of the ore fluids at the Alaska-Juneau gold deposit: 978, p. 92-95.

Hessin, T.D., 1982, Geochemical studies in the West Chichagof-Yakobi Wilderness: 844, p. $135-136$.

Himelberg, G.R., Ford, A.B., Brew, D.A., and Van Horn, Stephen, 1985, Chemical zonation of garnet in pelitic rocks of the Coast plutonic-metamorphic complex near Juneau: 945 , p. 91-92.

Hudson, Travis, Elliott, R.L., and Smith, J.G., 1978, Chemistry of Quartz Hills intrusive rocks, Ketchikan quadrangle: 772-B, p. B83-B85.

Johnson, B.R., Forn, C.L., Hoffman, J.D., Brew, D.A., and Nutt, C.J., 1977, Geochemical sampling of stream sediments, Tracy Arm, southeastern Alaska: $751-B$, p. B80-B82.

LeHuray, A.P., Stowel1, H.S., and Church, S.E., 1985, Lead isotopes from volcanogenic massive sulfide deposits in the Alexander terrane: 945, p. 95-96.

Staatz, M.H., 1977, I and $L$ vein system, Bokan Mountain, Prince of Wales Island: 751-B, P. B74-B75.

Stowel1, Harold, 1985, Sphalerite geobarometry in the Coast Range megalineament zone near Holkham Bay: 945, p. 96-99. 


\section{Geochronology}

Brew, D.A., Loney, R.A., Kistler, R.W., Czamanske, G.K., Gromme, C.S., and Tatsumoto, Mitsunobu, 1977, Probable Precambrian or lower Paleozoic rocks in the Fairweather Range, Glacier Bay National Monument, Alaska: 751-B, p. B91-B93.

Brew, D.A., and Morrel1, R.P., 1979, Correlation of the Sitka Graywacke, unnamed rocks in the Fairweather Range, and Valdez Group, southeastern and south-central Alaska: 804-B, p. B123-B125.

Churkin, Michael, Jr., and Eberlein, G.D., 1977, Correlation of the rocks of southeastern Alaska with other parts of the Cordillera: 751-B, p. B69-B72.

Decker, J.E., and Plafker, George, 1982, Correlation of rocks in the Tarr Inlet suture zone with the Kelp Bay Group: 844, p. 119-123.

Elliott, R.L., Koch, R.D., and Robinson, S.W., 1981, Age of basalt flows in the Blue River valley, Bradfield Canal quadrangle: 823-B, p. B115-B116.

Gehrels, G.E., Brew, D.A., and Saleeby, J.B., 1984, Progress report on U/Pb (zircon) geochronologic studies in the Coast plutonic-metamorphic complex east of Juneau, southeastern Alaska: 939, p. 100-102.

Loney, R.A., Himmelberg, G.R., and Shew, Nora, 1987, Salt Chuck palladium-bearing ultramafic body, Prince of Wales Island: 998, p. 126-127.

Saleeby, J.B., Gehrels, G.E., Eberlein, G.D., and Berg, H.C., 1984, Progress in lead/uranium zircon studies of lower Paleozoic rocks of the southern Alexander terrane: 868 , p. $110-113$.

\section{Geophysics}

Barnes, D.F., 1984, No measurable gravity change at Glacier Bay regional uplift area: 939 , P. 88-90. 1986, Gravity data indicate large mass and depth of the gabbro body at Haines: 978 , p. 88-92.

Barnes, D.F., and Watts, R.D., 1977, Geophysical surveys in Glacier Bay National Monument: 751-B, P. B93-B94.

Brew, D.A., Himmelberg, G.R., Ford, A.B., and Jachens, R.C., 1987, Ultramafic and mafic sills in the vicinity of the Treadwell gold deposits, Douglas Island, southeastern Alaska: 998, p. 119-123.

Mankinen, E.A., and Plafker, George, 1987, Paleomagnetic evidence for a latest Pliocene and early Pleistocene age of the upper Yakataga Formation on Middleton Island, Alaska: 998 , p. 132-136.

Panuska, B.C., Decker, J.E., and Berg, H.C., 1984, A preliminary paleomagnetic study of the Gravina-Nutzotin belt, southern and southeastern Alaska: 868,

p. $117-120$.

\section{Geothermal studies}

Gehrels, G.E., and Taylor, H.P., Jr., 1984, Fossil hydrothermal systems in the Ketchikan area, southeastern Alaska: 868, p. 134-136.

\section{Hydrology}

Balding, G.0., 1976, Aquifer investigations in Mendenhall Valley near Juneau: 733, p. 60 .

1979, Surface-water data from molybdenum resource area, Keta River basin: 804-B, P. B131-B 132 . 
Dearborn, L.L., and Balding, G.0., 1979, Ground-water data from molybdenum resource area, Keta River basin: 804-B, p. B 131 .

Erdman, J.A., and Motooka, J.M., 1985, Biogeochemical response at the Greens Creek massive sulfide deposit, Admiralty Island: 945, p. 88-91.

McCoy, G.A., 1976, Limnological investigations in southeastern Alaska: 733, p. 61.

\section{Marine geology}

Carlson, P.R., Wheeler, M.C., Molnia, B.F., and Atwood, T.J., 1979, Neoglacial sedimentation in Glacier Bay, Alaska: 804-B, P. B114-B116.

Stephens, Christopher, 1978, Seismicity near Icy Bay, Alaska, and in the eastern Gulf of Alaska: $772-B$, P. B96-B97.

\section{Metamorphic geology}

Brew, D.A., and Ford, A.B., 1981, The Coast plutonic complex sill, southeastern Alaska: 823-B, p. B96-B99.

1984, The northern Coast plutonic-metamorphic complex, southeastern Alaska and northwestern British Columbia: 868, p. 120-124.

1984, Tectonostratigraphic terranes in the Coast plutonic-metamorphic complex, southeastern Alaska: 939, p. 90-93.

Brew, D.A., Ford, A.B., Grybeck, Donald, Johnson, B.R., and Nutt, C.J., 1976, Key foliated quartz diorite sill along southwest side of coast Range complex, northern southeastern Alaska: 733, p. 60 .

Brew, D.A., Loney, R.A., Kistler, R.W., Czamanske, G.K., Gromme, C.S., and Tatsumoto, Mitsunobu, 1977, Probable Precambrian or lower Paleozoic rocks in the Fairweather Range, Glacier Bay National Monument, Alaska: 751-B, p. B91-B93.

Douglass, S.L., and Brew, D.A., 1985, Polymetamorphism in the eastern Petersburg quadrangle, southeastern Alaska: 967 , p. 89-92.

Ford, A.B., and Brew, D.A., 1977, Truncation of regional metamorphic zonation pattern of the Juneau, Alaska, area by the Coast Range batholith: 751-B, P. B85-B87. 1981 , Orthogneiss of Mount Juneau--An early phase of Coast Mountains plutonism involved Barrovian regional metamorphism near Juneau: 823-B, P. B99-B102.

Gehrels, G.E., Brew, D.A., and Saleeby, J.B., 1984, Progress report on U/Pb (zircon) geochronologic studies in the Coast plutonic-metamorphic complex east of Juneau, southeastern Alaska: 939, p. 100-102.

Himelberg, G.R., Ford, A.B., and Brew, D.A., 1984, Progressive metamorphism of pelitic rocks in the Juneau area, southeastern Alaska: 868, p. 131-134. 1984, Reaction isograds in pelitic rocks of the Coast plutonic-metamorphic complex near Juneau, Alaska: 939, p. 105-108.

Karl, Susan, and Brew, D.A., 1984, Migmatites of the Coast plutonic-metamorphic complex, southeastern Alaska: 939, p. 108-111.

Koch, R.D., Elliott, R.L., Smith, J.G., and Berg, H.C., 1977, Metamorphosed trondjhemite of the Alexander terrane in Coast Range plutonic complex: 751-B, P. B72-B74.

Stowe11, Harold, 1985, Sphalerite geobarometry in the Coast Range megalineament zone near Holkham Bay: 945 , p. 96-99.

\section{Paleontology}

Brew, D.A., Ford, A.B., and Garwin, S.L., 1985, Fossiliferous Middle and (or) Upper Triassic rocks within the Coast plutonic-metamorphic complex southeast of Skagway: 967 , p. 86-89. 
Dutro, J.T., Jr., Armstrong, A.K., Douglass, R.C., and Mamet, B.L., 1981, Carboniferous biostratigraphy, southeastern Alaska: 823-B, P. B94-B96.

Jones, D.L., Berg, H.C., Coney, P.J., and Harris, Anita, 1981, Structural and stratigraphic significance of Upper Devonian and Mississippian fossils from the Cannery Formation, Kupreanof Island, southeastern Alaska: 823-B, P. B109-B112.

Marincovich, Louie, Jr., 1976, Miocene mollusks from the Topsy Formation, Lituya district: 733 , p. 58 .

Plafker, George, Hudson, Travis, and Silberling, N.J., 1979, Late Triassic fossils from a sequence of volcanic and sedimentary rocks on the Chilkat Peninsula, southeastern Alaska: 804-B, P. B107-B110.

Savage, N.M., Eberlein, G.D., and Churkin, Michael, Jr., 1977, Early Devonian conodonts found with a classical Upper Silurian brachiopod fauna, southeastern Alaska: $751-B$, P. B 79-B 80 .

Silberling, N.J., Wardlaw, B.R., and Berg, H.C., 1982, New paleontologic age determinations from the Taku terrane, Ketchikan area, southeastern Alaska: 844, p. 117-119.

\section{Petrology; petrography}

Brew, D.A., 1987, Cenozoic magmatism in southeastern Alaska abstract : 998, P. 137. Brew, D.A., Sonnevil, R.A., Hunt, S.J., and Ford, A.B., 1981, Newly recognized alkali granite stock, southwestern Kupreanof Island, Alaska: 823-B, P. B108-B109.

Brew, D.A., Himmelberg, G.R., Ford, A.B., and Jachens, R.C., 1987, Ultramafic and mafic sills in the vicinity of the Treadwell gold deposits, Douglas Island, southeastern Alaska: 998, p. 119-123.

Burrel1, P.D., 1984, Cretaceous plutonic rocks, Mitkof and Kupreanof Islands, Petersburg quadrangle, southeastern Alaska: 868, p. 124-126. 1984, Late Cretaceous plutonic rocks, Petersburg quadrangle, southeast Alaska: 939, P. 93-96.

Ford, A.B., and Brew, D.A., 1987, The Wright Glacier volcanic plug and dike swarm, southeastern Alaska: 998 , p. 116-118.

Himmelberg, G.R., Ford, A.B., and Brew, D.A., 1984, Progressive metamorphism of pelitic rocks in the Juneau area, southeastern Alaska: 868, p. 131-134. 1984, Reaction isograds in pelitic rocks of the Coast plutonic-metamorphic complex near Juneau, Alaska: 939, p. 105-108. 1985, U1tramafic bodies in the Coast plutonic-metamorphic complex near Skagway, southeastern Alaska: 967, p. 92-93. 1986, Chemical composition of olivine and orthopyroxene in peridotite of the Coast plutonic-metamorphic complex near Skagway: 978, p. 95-99. 1986, The occurrence and chemical composition of chloritoid in the metamorphic rocks of the Coast plutonic-metamorphic complex: 978, p. 99-102.

Himelberg, G.R., Ford, A.B., Brew, D.A., and Van Horn, Stephen, 1985, Chemical zonation of garnet in pelitic rocks of the Coast plutonic-metamorphic complex near Juneau: 945 , p. 91-92.

Hudson, Travis, Elliott, R.L., and Smith, J.G., 1977, Investigations of the Wilson Arm molybdenite deposit: 751-B, P. B 74 . 1978, Chemistry of Quartz Hills intrusive rocks, Ketchikan quadrangle: 772-B, p. B83-B85.

Hunt, S.J., 1984, Preliminary study of a zoned leucocratic-granite body on central Etolin Island, southeastern Alaska: 868, p. 128-130.

Koch, R.D., and Elliott, R.I., 1984, Late Oligocene gabbro near Ketchikan, southeastern Alaska: 868 , p. 126-128.

Loney, R.A., Himmelberg, G.R., and Shew, Nora, 1987, Salt Chuck palladium-bearing ultramafic body, Prince of Wales Island: 998, p. 126-127. 
Webster, J.H., 1984, Preliminary report on a large granitic body in the Coast Mountains, northeast Petersburg quadrangle, southeastern Alaska: 939, P. 116-118.

Zen, E-An, and Hammarstrom, J.M., 1984, Mineralogy and a petrogenetic model for the tonalite pluton at Bushy Point, Revillagigedo Island, Ketchikan $1^{\circ} \times 2^{\circ}$ quadrangle, southeastern Alaska: 939, p. 118-123.

\section{Quaternary geology}

Carlson, P.R., Wheeler, M.C., Molnia, B.F., and Atwood, T.J., 1979, Neoglacial sedimentation in Glacier Bay, Alaska: 804-B, p. B114-B116.

Plafker, George, Hudson, Travis, and Rubin, Meyer, 1976, Late Holocene offset features along the Fairweather fault: 733, p. 57-58.

Riehle, J.R., and Brew, D.A., 1984, Explosive latest Pleistocene(?) and Holocene activity of the Mount Edgecumbe volcanic field, Alaska: 939, p. 111-115.

\section{Remote sensing}

LeCompte, J.R., and Steele, W.C., 1981, Landsat data interpretation in the southcentral Brooks Range and in southeastern Alaska: 823-B, P. B1-B3.

Steele, W.C., LeCompte, J.R., and Albert, N.R.D., 1979, Landsat color mosaic of southeastern Alaska: 804-B, P. B3.

\section{Sedimentary geology}

Brew, D.A., and Morrel1, R.P., 1979, Correlation of the Sitka Graywacke, unnamed rocks in the $F$ airweather Range, and Valdez Group, southeastern and south-central Alaska: 804-B, p. B123-B125.

Carlson, P.R., Wheeler, M.C., Molnia, B.F., and Atwood, T.J., 1979, Neoglacial sedimentation in Glacier Bay, Alaska: 804-B, p. B114-B116.

Decker, John, Nilsen, T.H., and Karl, Susan, 1979, Turbidite facies of the Sitka Graywacke, southeastern Alaska: 804-B, P. B125-B129.

Decker, J.E., and Plafker, George, 1982, Correlation of rocks in the Tarr Inlet suture zone with the Kelp Bay Group: 844 , p. 119-123.

Jones, D.L., Berg, H.C., Coney, P.J., and Harris, Anita, 1981, Structural and stratigraphic significance of Upper Devonian and Mississippian fossils from the Cannery Formation, Kupreanof Island, southeastern Alaska: 823-B, P. B109-B112.

Karl, Susan, 1984, Recognition of the Burnt Island Conglomerate on the Screen Islands, southeastern Alaska: 868, p. 115-117.

Mankinen, E.A., and Plafker, George, 1987, Paleomagnetic evidence for a latest Pliocene and early Pleistocene age of the upper Yakataga Formation on Middleton Island, Alaska: 998, p. 132-136.

Plafker, George, Hudson, Travis, and Silberling, N.J., 1979, Late Triassic fossils from a sequence of volcanic and sedimentary rocks on the Chilkat Peninsula, southeastern Alaska: 804-B, p. B107-B 110 .

\section{Seismicity}

Osbakken, W.E., 1976, Automated observatory system installed at Sitka Observatory: 733 , p. 60 .

Stephens, Christopher, 1978, Seismicity near Icy Bay, Alaska, and in the eastern Gulf of Alaska: $772-B$, P. B96-B97.

Stephens, Christopher, and Lahr, J.C., 1979, Seismicity in southern and southeastern Alaska: 804-B, p. B104-B 106 . 
Stephens, C.D., and Lahr, J.C., 1982, Seismic studies in southern and southeastern Alaska: 844 , p. 89-93.

\section{Structural geology; tectonics}

Barton, C.C., and Light, T.D., 1987, Structural fabric analysis of the Perseverance Slate and gold-bearing quartz veins in the south ore body of the Alaska-Juneau lode system, southeastern Alaska: 998, p. 110-112.

Berg, H.C., 1979, Significance of geotectonics in the metallogenesis and resource appraisal of southeastern Alaska--A progress report: 804-B, P. B116.

Berg, H.C., Smith, J.G., Elliott, R.L., and Koch, R.D., 1977, Structural elements of Insular Belt and Coast Range plutonic complex near Ketchikan, Alaska--A progress report: $751-B, P . B 76-B 78$.

Brew, D.A., 1987, Cenozoic magmatism in southeastern Alaska abstract : 998, p. 137.

Brew, D.A., Berg, H.C., Morrell, R.P., Sonnevil, R.A., Hunt, S.J., and Huie, Carl, 1979, The Tertiary Kuiu-Etolin volcanic-plutonic belt, southeastern Alaska: $804-B$, P. B129-B 130 .

Brew, D.A., Carlson, Christine, and Nutt, C.J., 1976, Apparent pre-middle Tertiary right-lateral offset on Excursion Inlet fault, Glacier Bay National Monument: 733 , p. 59.

Brew, D.A., and Ford, A.B., 1977, Coast Range megalineament and Clarence strait lineament on west edge of Coast Range batholithic complex, southeastern Alaska: $751-B$, p. B 79 . 1981, The Coast plutonic complex sill, southeastern Alaska: 823-B, P. B96-B99. 1984, The northern Coast plutonic-metamorphic complex, southeastern Alaska and northwestern British Columbia: 868, p. 120-124. 1984, Tectonostratigraphic terranes in the Coast plutonic-metamorphic complex, southeastern Alaska: 939, p. 90-93. 1985, Southeastern Alaska coincident zone: 967, p. 82-86.

1987, The Meade Glacier Fault--An important tectonic boundary in the Northern Cordillera, southeastern Alaska: 998, p. 113-115.

Brew, D.A., Johnson, B.R., Ford, A.B., and Morrell, R.P., 1978, Intrusive rocks in the Fairweather Range, Glacier Bay National Monument: 772-B, p. B88-B90.

Brew, D.A., Loney, R.A., Kistler, R.W., Czamanske, G.K., Gromme, C.S., and Tatsumoto, Mitsunobu, 1977, Probable Precambrian or lower Paleozoic rocks in the Fairweather Range, Glacier Bay National Monument, Alaska: 751-B, P. B91-B93.

Brew, D.A., and Morrell, R.P., 1978, Tarr Inlet suture zone, Glacier Bay National Monument, Alaska: 772-B, P. B90-B91.

1979, Correlation of the Sitka Graywacke, unnamed rocks in the Fairweather Range, and Valdez Group, southeastern and south-central Alaska: 804-B, p. B123-B125. 1979, Intrusive rock belts of southeastern Alaska: 804-B, P. B116-B121. 1979, The Wrangell terrane ("Wrangellia") in southeastern Alaska--The Tarr Inlet suture zone with its northern and southern extensions: 804-B, p. B121-B123.

Brew, D.A., Sonnevil, R.A., Hunt, S.J., and Ford, A.B., 1981, Newly recognized alkali granite stock, southwestern Kupreanof Island, Alaska: 823-B, P. B108-B109.

Churkin, Michael, Jr., and Eberlein, G.D., 1977, Correlation of the rocks of southeastern Alaska with other parts of the Cordillera: 751-B, p. B69-B72.

Decker, J.E., and Plafker, George, 1982, Correlation of rocks in the Tarr Inlet suture zone with the Kelp Bay Group: 844, p. 119-123.

Decker, John, and Johnson, B.R., 1981, The nature and position of the Border Ranges fault on Chichagof Island: 823-B, P. B102-B104.

Ford, A.B., and Brew, D.A., 1977, Truncation of regional metamorphic zonation pattern of the Juneau, Alaska, area by the Coast Range batholith: 751-B, p. B85-B87. 
Gehrels, G.E., Saleeby, J.B., and Berg, H.C., 1984, Geologic framework of Paleozoic rocks on southern Annette and Hotspur Islands, southern Alexander terrane: 868, p. 113-115.

Himmelberg, G.R., Brew, D.A., and Ford, A.B., 1985, Ultramafic bodies in the Coast plutonic-metamorphic complex near Skagway, southeastern Alaska: 967, p. 92-93.

Hudson, Travis, Dixon, Kirk, and Plafker, George, 1982, Regional uplift in southeastern Alaska: 844, p. 132-135.

Hudson, Travis, and Plafker, George, 1981, Emplacement of the Crillon-La Perouse pluton, Fairweather Range: 823-B, p. B90-B94.

Hudson, Travis, Plafker, George, and Dixon, Kirk, 1982, Horizontal offset history of the Chatham Strait fault: 844, p. 128-132.

Hunt, S.J., and Brew, D.A., 1986, Geometric structural analysis of part of the Coast plutonic-metamorphic complex east of Wrangell: 978, p. 102-108.

Jones, D.L., Berg, H.C., Coney, P.J., and Harris, Anita, 1981, Structural and stratigraphic significance of Upper Devonian and Mississippian fossils from the Cannery Formation, Kupreanof Island, southeastern Alaska: 823-B, p. B109-B112.

Karl, Susan, and Brew, D.A., 1984, Migmatites of the Coast plutonic-metamorphic complex, southeastern Alaska: 939, p. 108-111.

Karl, Susan, Decker, J.E., and Johnson, B.R., 1982, Discrimination of Wrangellia and the Chugach terrane in the Kelp Bay Group on Chichagof and Baranof Islands, southeastern Alaska: 844 , P. 124-128.

Koch, R.D., Elliott, R.L., Smith, J.G., and Berg, H.C., 1977, Metamorphosed trondjhemite of the Alexander terrane in Coast Range plutonic complex: 751-B, P. B72-B74.

Koch, R.D., Smith, J.G., and Elliott, R.L., 1977, Miocene or younger strike-slip(?) fault at Canoe Passage, southeastern Alaska: 751-B, P. B76.

LeHuray, A.P., Stowell, H.S., and Church, S.E., 1985, Lead isotopes from volcanogenic massive sulfide deposits in the Alexander terrane: 945, p. 95-96.

Plafker, George, Hudson, Travis, and Rubin, Meyer, 1976, Late Holocene offset features along the Fairweather fault: 733, p. 57-58.

Plafker, George, Jones, D.L., Hudson, Travis, and Berg, H.C., 1976, The Border Ranges fault system in the Saint Elias Mountains and Alexander Archipelago: 733, p. $14-16$.

Silberling, N.J., Wardlaw, B.R., and Berg, H.C., 1982, New paleontologic age determinations from the Taku terrane, Ketchikan area, southeastern Alaska: 844, p. 117-119.

Zen, E-An, and Hammarstrom, J.M., 1984, Mineralogy and a petrogenetic model for the tonalite pluton at Bushy Point, Revillagigedo Island, Ketchikan $1^{\circ} \times 2^{\circ}$ quadrangle, southeastern Alaska: 939, p. 118-123.

\section{Surficial geology}

Elliott, R.L., Koch, R.D., and Robinson, S.W., 1981, Age of basalt flows in the Blue River valley, Bradfield Canal quadrangle: 823-B, p. B115-B116.

Yehle, L.A., 1977, Reconnaissance engineering geology and geologic hazards of the Metlakatla area, Annette Island: 751-B, p. B72.

1979, Reconnaissance engineering geology and geologic hazards of the Petersburg area, southeastern Alaska: 804-B, P. B130-B131.

Volcanoes; volcanic rocks

Brew, D.A., Karl, S.M., and Tobey, E.F., 1985, Re-interpretation of the age of the Kuiu-Etolin belt volcanic rocks, Kupreanof Island, southeastern Alaska: 945, p. 86-88. 
Plafker, George, Hudson, Travis, and Silberling, N.J., 1979, Late Triassic fossils from a sequence of volcanic and sedimentary rocks on the Chilkat Peninsula, southeastern Alaska: 804-B, p. B107-B110.

Riehle, J.R., and Brew, D.A., 1984, Explosive latest Pleistocene(?) and Holocene activity of the Mount Edgecumbe volcanic field, Alaska: 939, p. 111-115. 


\section{Offshore Alaska}

\section{Economic geology}

Nelson, C.H., Jenne, E.A., Larsen, B.R., and Sorg, D.H., 1976, Mercury dispersal in Kuskokwim River and Bay: 733, p. 43-44.

\section{General geology}

Childs, J.R., Scholl, D.W., and Vallier, Tracy, 1981, Onshore and offshore studies, Amlia Island area, Aleutian Ridge: 823-B, p. B134-B138.

Toimil, L.J., and Grantz, Arthur, 1976, Seabed morphology adjacent to an "island" of grounded ice in the Arctic Ocean northwest of Point Barrow: 733, p. 16-17.

\section{Geochemistry}

Simpson, G.L., Vallier, T.L., Pearl, J.E., and Lee-Wong, Florence, 1979, Potassiumargon ages and geochemistry of basalt dredged near Saint George Island, southern Bering Sea: 804-B, P. B134-B135.

\section{Geochronology}

Bruns, T.R., Vallier, T.L., Pickthorn, L.B., and von Huene, Roland, 1987, Volcanicarc dacite and early Miocene basalt dredged from the Shumagin margin, Alaska: 998, p. 143-146.

Vallier, T.L., and Herman, B.M., 1987, Petrology, age, and orignal tectonic setting of basalt from the $\mathrm{St}$. George Basin COST No. 1 Well, southern Bering Sea: 998 , p. 165-169.

\section{Geophysics}

Cooper, A.K., 1977, Marine geophysical investigations in the Bering Sea basin: 751-B, P. B98-B 100 .

Cooper, A.K., and Marlow, M.S., 1979, Geologic and geophysical cruise across the outer Bering continental margin: 804-B, P. B132-B134. 1984, Geophysical and geological studies of the Bering Sea Shelf: 939 , p. 123-127.

Fisher, M.A., 1982, Preliminary interpretation of geophysical data over the projected offshore location of the Kaltag fault: 844, p. 136-139.

Fisher, M.A., Holmes, M.L., and Patton, W.W., Jr., 1981, Preliminary interpretation of the geologic structure beneath the northern Bering Sea shelf, including Norton Basin: 823-B, p. B118-B121.

Marlow, M.S., 1977, Resource assessment and geophysical exploration of the southern Bering Sea shelf: 751-B, P. B97-B98.

\section{Geothermal studies}

Cooper, A.K., 1978, Heat flow and organic gas measurements from the Aleutian Basin, Bering Sea: 772-B, P. B92-B94.

\section{Hydrology}

Anderson, G.S., 1976, Water-resources reconnaissance of St. George Island, Pribilof Islands: 733, p. 43. 
Nelson, C.H., Jenne, E.A., Larsen, B.R., and Sorg, D.H., 1976, Mercury dispersal in Kuskokwim River and Bay: 733, p. 43-44.

\section{Marine geology}

Barnes, P.W., Graves, Scot, and Reimnitz, Erk, 1987, Beaufort Sea coastal currents--A divergence near Barter Island, Alaska?: 998, p. 139-142.

Barnes, P.W., and Reimnitz, Erk, 1976, Sediment-ice interaction in the Beaufort Sea: 733 , p. 17-21.

Brouwers, E.M., and McDougall, Kristin, 1984, Preliminary analysis of microfauna from selected bottom grab samples, southern Bering Sea: 868, p. 140-141.

Bruns, T.R., Fisher, M.A., Carlson, P.R., Rearic, D.M., and Parson, L.M., 1987, GLORIA images obtained in the TACT corridor of the Aleutian convergent margin, northern Gulf of Alaska abstract : 998 , p. 170.

Bruns, T.R., Vallier, T.L., Pickthorn, L.B., and von Huene, Roland, 1987, Volcanicarc dacite and early Miocene basalt dredged from the Shumagin margin, Alaska: 998 , p. 143-146.

Bruns, T.R., and von Heune, Roland, 1977, Sedimentary basins on the Shumagin shelf, western Gulf of Alaska: 751-B, P. B97.

Carlson, P.R., Karl, H.A., Johnson, K.A., and Fischer, J.M., 1982, Submarine canyons flanking Navarin Basin, Bering Sea: 844, p. 139-141.

Carlson, P.R., and Molnia, B.F., 1976, Submarine mass movement of Holocene sediments seaward of the Copper River: 733 , p. 55-56.

Carlson, P.R., Molnia, B.F., Bruns, T.R., and Whitney, J.W., 1977, Shelf-edge scarps in the northern Gulf of Alaska: 751-B, P. B96-B97.

Carlson, P.R., Plafker, George, Bruns, T.R., and Levy, W.P., 1979, Seaward extension of the Fairweather fault: 804-B, P. B135-B139.

Childs, J.R., Scholl, D.W., and Vallier, Tracy, 1981, Onshore and offshore studies, Amlia Island area, Aleutian Ridge: 823-B, P. B134-B138.

Cooper, A.K., 1977, Marine geophysical investigations in the Bering Sea basin: 751-B, P. B98-B100.

Cooper, A.K., and Marlow, M.S., 1979, Geologic and geophysical cruise across the outer Bering continental margin: 804-B, P. B132-B134. 1984, Geophysical and geological studies of the Bering Sea Shelf: 939, p. $123-127$.

Eittreim, Stephen, Grantz, Arthur, and Whitney, O.T., 1977, Tectonic imprints on sedimentary deposits in Hope basin: 751-B, p. B100-B103.

Fisher, M.A., 1982, Preliminary interpretation of geophysical data over the projected offshore location of the Kaltag fault: 844, p. 136-139.

Fisher, M.A., Holmes, M.L., and Patton, W.W., Jr., 1981 , Preliminary interpretation of the geologic structure beneath the northern Bering Sea shelf, including Norton Basin: 823-B, p. B118-B121.

Johnson, Kirk, Mitchell, Heidi-Lynn, and Nelson, C.H., 1984, Gray whale feeding ecology and sea-floor interaction in the northern Bering Sea--Preliminary results: 939 , p. 127-132.

Karl, H.A., Carlson, P.R., and Lamb, Beth, 1982, Sediment waves in the head of Navarinsky, Pervenets, and Zhemchug Canyons, northwestern Bering Sea: 844, p. 141-143.

Karl, H.A., Gardner, J.V., and Huggett, Quentin, 1987, GLORIA images of Zhemchug Canyon and Bering channel-fan system, Bering Sea: 998, p. 147-151.

Lins, H.F., Jr., 1978, Analysis of remotely sensed data for use in evaluating the onshore impacts of offshore petroleum development at Kenai, Alaska: 772-B, P. B76-B78.

Marlow, Mike, 1978, Navarin basin, northwest Bering Sea shelf: 772-B, p. B96. 
Marlow, M.S., Carlson, P.R., Dadisman, S.V., Rearic, D.M., Maple, E.J., and Parson, L.M., 1987, GLORIA side-scan and geophysical surveys of the central Bering Sea in 1986: 998 , p. 152-156.

McClellan, P.H., Fisher, M.A., von Heune, Roland, and Moore, G.W., 1982, Summary and discussion of microfossil biostratigraphy in the western Gulf of Alaska: 844, p. $148-151$.

Molnia, B.F., 1981, Depth changes in Icy Bay, Alaska, caused by sedimentation and melting of ice-cored moraine: 823-B, P. B125-B128.

1981, Distribution of gas-charged sediment and pockmarks in the northeastern Gulf of Alaska, Yakutat Bay to Cross Sound: 823-B, p. B125.

Molnia, B.F., and Carlson, P.R., 1976, Surface sedimentary units of the northern Gulf of Alaska continental shelf: 733, p. 56-57.

Molnia, B.F., and Rappeport, M.L., 1982, Mosaic of pockmarked sea-floor area near the Alsek River, northeastern Gulf of Alaska: 844, p. 146-148.

Nelson, C.H., 1977, Ice gouging and other environmental geologic problems of northern Bering Sea: 751-B, P. B98.

Nelson, C.H., and Creager, J.S., 1976, Displacement of Yukon-derived sediment from northern Bering Sea to southern Chukchi Sea during the Holocene: 733, p. 10-11.

Nelson, C.H., Jenne, E.A., Larsen, B.R., and Sorg, D.H., 1976, Mercury dispersal in Kuskokwim River and Bay: 733, p. 43-44.

Nelson, C.H., Rowland, R.W., and Stoker, S.W., 1976, Sedimentary facies and structures of the northern Bering epicontinental shelf: 733, p. 43.

Phillips, R.L., and Colgan, M.W., 1987, Vibracore stratigraphy of the northeastern Chukchi Sea: 998 , p. 157-160.

Plafker, George, Carlson, P.R., Coonrad, W.L., Hunt, S.J., and Quinterno, Paula, 1979, Geologic implications of 1978 outcrop sample data from the continental slope in the eastern Gulf of Alaska: 804-B, p. B143-B146.

Plafker, George, Winkler, G.R., Hunt, S.J., Bartsch-Winkler, Sus an, Coonrad, W.L., and Quinterno, Paula, 1978, Outcrop samples from the Continental Slope in the eastern Gulf of Alaska: 772-B, P. B97-B101.

Poore, R.Z., and Bukry, David, 1979, Preliminary report on Eocene calcareous plankton from the eastern Gulf of Alaska continental slope: 804-B, p. B141-B143.

Rau, W.W., 1979, Unusually well preserved and diverse Eocene foraminifers in dredge samples from the eastern Gulf of Alaska continental slope: 804-B, p. B139-B141. 1981, Unusually diverse and well preserved Eocene foraminifers in dredge samples from the eastern Gulf of Alaska continental slope: 823-B, B131-B134.

Rearic, D.M., 1985, Character and implications of new ice gouges in eastern Harrison Bay, Beaufort Sea: 945 , p. 99-101.

Reimnitz, Erk, and Kempema, E.W., 1987, Thirty-four-year shoreface evolution at a rapidly retreating arctic coastal site: 998 , p. 161-164.

Simpson, G.L., Vallier, T.L., Pearl, J.E., and Lee-Wong, Florence, 1979, Potassiumargon ages and geochemistry of basalt dredged near Saint George Island, southern Bering Sea: 804-B, p. B134-B135.

Smith, Peggy, 1985, Late Quaternary geology of the Beaufort Sea inner shelf near Prudhoe Bay: 945 , p. 100-103.

Thenhaus, P.C., Ziony, J.I., Diment, W.H., Hopper, M.G., Perkins, D.M., Hanson, S.L., and Algermissen, S.T., 1982, Probabalistic estimates of maximum seismic horizontal ground motion on rock in Alaska and the adjacent outer continental shelf: 844, p. 5-9.

Thor, D.R., and Nelson, Hans, 1978, Environmental geologic studies in the northern Bering Sea: 772-B, p. B94-B95. 1981, Environmental geologic studies of the northern Bering Sea: 823-B, P. B121-B122. 
Toimil, L.J., and Grantz, Arthur, 1976, Seabed morphology adjacent to an "island" of grounded ice in the Arctic Ocean northwest of Point Barrow: 733, p. 16-17.

Vallier, T.L., and Herman, B.M., 1987, Petrology, age, and orignal tectonic setting of basalt from the St. George Basin CosT No. 1 Well, southern Bering Sea: 998 , p. 165-169.

Whitney, J.W., and Thurston, D.K., 1981, Geologic constraints for petroleum development of the lower Cook Inlet, Alaska, Outer Continental Shelf lease area: $823-B$, P. B122-B124.

\section{Oil and gas}

Barnes, Ivan, Plafker, George, White, L.D., and Armstrong, A.K., 1982, Potential natural gas in the Gulf of Alaska indicated by calcite depleted in carbon-13: 844 , p. 143-146.

Cooper, A.K., 1978, Heat flow and organic gas measurements from the Aleutian Basin, Bering Sea: 772-B, p. B92-B94.

Grantz, Arthur, Boucher, Gary, and Whitney, 0.T., 1976, Possible solid gas hydrate and natural gas deposits beneath the continental slope of the Beaufort sea: 733 , p. 17.

Lins, H.F., Jr., 1978, Analysis of remotely sensed data for use in evaluating the onshore impacts of offshore petroleum development at Kenai, Alaska: 772-B, p. B76-B78.

Marlow, M.S., 1977, Resource assessment and geophysical exploration of the southern Bering Sea shelf: 751-B, p. B97-B98. 1978, Navarin basin, northwest Bering Sea shelf: 751-B, P. B96.

Molnia, B.F., 1981, Distribution of gas-charged sediment and pockmarks in the northeastern Gulf of Alaska, Yakutat Bay to Cross Sound: 823-B, P. B125.

Whitney, J.W., and Thurston, D.K., 1981, Geologic constraints for petroleum development of the lower Cook Inlet, Alaska, Outer Continental Shelf lease area: 823-B, P. B122-B124.

\section{Paleontology}

McClellan, P.H., Fisher, M.A., von Heune, Roland, and Moore, G.W., 1982, Summary and discussion of microfossil biostratigraphy in the western Gulf of Alaska: 844, p. $148-151$.

Poore, R.Z., and Bukry, David, 1979, Preliminary report on Eocene calcareous plankton from the eastern Gulf of Alaska continental slope: 804-B, p. B141-B143.

Quinterno, Paula, Carlson, P.R., and Molnia, B.F., 1981, Benthic foraminifers as indicators of the Pleistocene-Holocene boundary in the eastern Gulf of Alaska: 823-B, P. B128-B 130 .

Rau, W.W., 1979, Unusually well preserved and diverse Eocene foraminifers in dredge samples from the eastern Gulf of Alaska continental slope: 804-B, P. B139-B14l. 1981, Unusually diverse and well preserved Eocene foraminifers in dredge samples from the eastern Gulf of Alaska continental slope: 823-B, B131-B134.

\section{Petrology; petrography}

Bruns, T.R., Vallier, T.L., Pickthorn, L.B., and von Huene, Roland, 1987, Volcanicarc dacite and early Miocene basalt dredged from the Shumagin margin, Alaska: 998, P. 143-146.

Vallier, T.L., and Herman, B.M., 1987, Petrology, age, and orignal tectonic setting of basalt from the St. George Basin COST No. 1 Well, southern Bering Sea: 998 , p. 165-169. 


\section{Quaternary geology}

Molnia, B.F., 1981, Depth changes in Icy Bay, Alaska, caused by sedimentation and melting of ice-cored moraine: 823-B, p. B125-B128.

Molnia, B.F., and Carlson, P.R., 1976, Surface sedimentary units of the northern Gulf of Alaska continental shelf: 733 , p. 56-57.

Quinterno, Paula, Carlson, P.R., and Molnia, B.F., 1981, Benthic foraminifers as indicators of the Pleistocene-Holocene boundary in the eastern Gulf of Alaska: 823-B, P. B128-B130.

Smith, Peggy, 1985, Late Quaternary geology of the Beaufort Sea inner shelf near Prudhoe Bay: 945, p. 100-103.

\section{Remote sensing}

Lins, H.F., Jr., 1978, Analysis of remotely sensed data for use in evaluating the onshore impacts of offshore petroleum development at Kenai, Alaska: 772-B, p. B76-B78.

Molnia, B.F., 1981, Distribution of gas-charged sediment and pockmarks in the northeastern Gulf of Alaska, Yakutat Bay to Cross Sound: 823-B, p. B125.

Molnia, B.F., and Rappeport, M.L., 1982, Mosaic of pockmarked sea-floor area near the Alsek River, northeastern Gulf of Alaska: 844, p. 146-148.

\section{Sedimentary geology}

Barnes, P.W., Graves, Scot, and Reimnitz, Erk, 1987, Beaufort Sea coastal currents--A divergence near Barter Island, Alaska?: 998, P. 139-142.

Barnes, P.W., and Reimnitz, Erk, 1976, Sediment-ice interaction in the Beaufort Sea: 733, p. $17-21$.

Bruns, T.R., and von Heune, Roland, 1977, Sedimentary basins on the Shumagin shelf, western Gulf of Alaska: 751-B, p. B97.

Eittreim, Stephen, Grantz, Arthur, and Whitney, 0.T., 1977, Tectonic imprints on sedimentary deposits in Hope basin: 751-B, p. B100-B103.

Johnson, Kirk, Mitchell, Heidi-Lynn, and Nelson, C.H., 1984, Gray whale feeding ecology and sea-floor interaction in the northern Bering Sea--Preliminary results: 939 , p. 127-132.

Karl, H.A., Carlson, P.R., and Lamb, Beth, 1982, Sediment waves in the head of Navarinsky, Pervenets, and Zhemchug Canyons, northwestern Bering Sea: 844, p. 141-143.

Molnia, B.F., 1981, Depth changes in Icy Bay, Alaska, caused by sedimentation and melting of ice-cored moraine: 823-B, p. B125-B128. 1981, Distribution of gas-charged sediment and pockmarks in the northeastern Gulf of Alaska, Yakutat Bay to Cross Sound: 823-B, p. B125.

Molnia, B.F., and Carlson, P.R., 1976, Surface sedimentary units of the northern Gulf of Alaska continental shelf: 733 , p. 56-57.

Molnia, B.F., and Rappeport, M.L., 1982, Mosaic of pockmarked sea-floor area near the Alsek River, northeastern Gulf of Alaska: 844, p. 146-148.

Nelson, C.H., Rowland, R.W., and Stoker, S.W., 1976, Sedimentary facies and structures of the northern Bering epicontinental shelf: $733, p .43$.

Phillips, R.L., and Colgan, M.W., 1987, Vibracore stratigraphy of the northeastern Chukchi Sea: 998, p. 157-160.

Plafker, George, Carlson, P.R., Coonrad, W.L., Hunt, S.J., and Quinterno, Paula, 1979, Geologic implications of 1978 outcrop sample data from the continental slope in the eastern Gulf of Alaska: 804-B, p. B143-B146. 
Plafker, George, Winkler, G.R., Hunt, S.J., Bartsch-Winkler, Susan, Coonrad, W.L., and Quinterno, Paula, 1978, Outcrop samples from the Continental Slope in the eastern Gulf of Alaska: 772-B, p. B97-B101.

Reimnitz, Erk, and Kempema, E.W., 1987, Thirty-four-year shoreface evolution at a rapidly retreating arctic coastal site: 998 , p. 161-164.

\section{Seismicity}

Thenhaus, P.C., Ziony, J.I., Diment, W.H., Hopper, M.G., Perkins, D.M., Hanson, S.L., and Algermissen, S.T., 1982, Probabalistic estimates of maximum seismic horizontal ground motion on rock in Alaska and the adjacent outer continental shelf: 844 , p. 5-9.

\section{Structural geology; tectonics}

Bruns, T.R., Fisher, M.A., Carlson, P.R., Rearic, D.M., and Parson, L.M., 1987, GLORIA images obtained in the TACT corridor of the Aleutian convergent margin, northern Gulf of Alaska abstract : 998 , p. 170.

Bruns, T.R., and Plafker, George, 1976, Structural style of part of the Outer Continental Shelf in the Gulf of Alaska Tertiary Province: 733, p. 13-14.

Bruns, T.R., Vallier, T.L., Pickthorn, L.B., and von Huene, Roland, 1987, Volcanicarc dacite and early Miocene basalt dredged from the Shumagin margin, Alaska: 998 , p. 143-146.

Bruns, T.R., and von Heune, Roland, 1977, Sedimentary basins on the Shumagin shelf, western Gulf of Alaska: 751-B, p. B97.

Carlson, P.R., Plafker, George, Bruns, T.R., and Levy, W.P., 1979, Seaward extension of the Fairweather fault: 804-B, P. B135-B139.

Eittreim, Stephen, Grantz, Arthur, and Whitney, 0.T., 1977, Tectonic imprints on sedimentary deposits in Hope basin: 751-B, P. B100-B103.

Fisher, M.A., Holmes, M.L., and Patton, W.W., Jr., 1981, Preliminary interpretation of the geologic structure beneath the northern Bering Sea shelf, including Norton Basin: 823-B, P. B118-B121.

Vallier, T.L., and Herman, B.M., 1987, Petrology, age, and orignal tectonic setting of basalt from the St. George Basin COST No. 1 Well, southern Bering Sea: 998, p. $165-169$.

\section{Surficial geology}

Nelson, C.H., 1977, Ice gouging and other environmental geologic problems of northern Bering Sea: 751-B, p. B98.

Rearic, D.M., 1985, Character and implications of new ice gouges in eastern Harrison Bay, Beaufort Sea: 945, p. 99-101.

Thor, D.R., and Nelson, Hans, 1978, Environmental geologic studies in the northern Bering Sea: 772-B, p. B94-B95. 1981, Environmental geologic studies of the northern Bering Sea: 823-B, P. B121-B122.

Whitney, J.W., and Thurston, D.K., 1981, Geologic constraints for petroleum development of the lower Cook Inlet, Alaska, Outer Continental Shelf lease area: $823-B$, P. B122-B124. 


\section{AUTHOR}

Ackerman, R.E.

Ager, T.A.

Ahlbrand $t$, T.S.

Albert, N.R.D.

Aleinikoff, J.N.

Algermissen, S.T.

All away, W.H., Jr.

Almquist, Carl

Ambos, E.L.

Anderson, G.S.

Angeloni, L.M.

Anonymous

Antweiler, J.C.

Armstrong, A.K.

Arth, Joseph

Ashley, G.M.

Ashley, R.P.

Atwood, D.E.

Atwood, T.J.

Bacon, C.R.

Bailey, E.A.

Balding, G.0.

Balin, Donna

Barker, Fred

Barnes, D.F.

Barnes, Ivan

Barnes, P.W.

Barton, C.C.

Bartsch-Winkler, Susan

Behrendt, E.C.

Beikman, H.M.

Bentz, J.L.

Berg, D.L.

Berg, H.C.

Bird, K.J.

Bischoff, J.L.

Blackford, Michael

Blanchard, D.C.

Blodgett, R.B.

Blome, C.D.

Blueford, J.R.

Blum, Joel

Bolm, J.G.

Booth, S.E.

Botinelly, Theodore

Boucher, Gary

Box, S.E.
PAGE NUMBER

29,40

$7,29,33,40,55,62,76$

$7,20,46,48,49$

$7,22,27,32,38,40,59,62,70,77,78,79,81$, 91

$7,27,60,61,72,74,75,78,79,81$

$32,39,40,97,100$

7,67

31,53

$17,18,73,80$

$7,35,39,73,95$

7,54

7,37

8,59

$8,16,41,45,46,48,69,75,76,77,90,98$

20,53

$19,43,46,47,49$

18,53

26,78

$12,89,91$

$15,61,62$

$17,41,42$

$8,14,85,88,89$

26,50

20,53

$8,11,38,41,43,73,79,80,88$

$8,21,62,98$

$8,96,99$

$8,85,92$

$8,9,21,27,29,46,73,74,76,77,78,79,97$, 100

9,39

9,38

$15,61,62$

21,51

$9,10,18,21,22,28,29,30,40,73,81,85,86$,

$88,89,90,91,92,93$

$9,12,14,18,42,43,45,46,50$

$19,60,62$

$9,22,79$

$9,16,41,43$

$9,45,61,63$

$17,26,29,46,49,61,66,76,78$

9,75

15,54

$27,55,56$

33,37

$17,33,38,85,87$

$9,18,43,44,98$

$9,10,56,65,66,67$ 
Bradbury, Platt

Brew, D.A.

Brigham, J.K.

Briskey, J.A.

Brookins, D.G.

Brosge, W.P.

Brouwers, E.M.

Bruns, T.R.

Bryn, Sean

Buh rmaster, C.L.

Bukry, David

Bund tzen, T.K.

Burack, A.C.

Burrell, P.D.

Burroughs, R.L.

Cady, J.W.

Callahan, J.E.

Campbel1, D.L.

Campbe11, R.B.

Carlson, Christine

Carlson, P.R.

Carter, Claire

Carter, L.D.

Carter, R.D.

Case, J.E.

Cathral1, J.B.

Chapman, R.M.

Childers, J.M.

Childs, J.R.

Christie, J.L.

Church, S.E.

Churkin, Michael, Jr.

Claypool, G.E.

Clough, J.G.

Cobb, E.H.

Colgan, M.W.

Collett, T.S.

Coney, P.J.

Connor, C.L.

Cooley, E.F.

Coonrad, W.L.

Cooper, A.K.

Coulter, H.W.

Cowing, D.J .

Cox, D.C.

Cox, D.P.

Creager, J.S.

Criley, E.E.

Crim, W.D.

Crory, F.E.
7,55

$10,11,15,17,18,19,20,21,22,26,29,70,72$,

$78,80,85,86,87,88,89,90,91,92,93,94$

$11,43,44,46,48$

$13,53,54$

$30,43,45$

$11,16,26,29,32,41,42,43,48,49,50,51$

$11,12,23,42,44,46,47,48,74,75,76,96$

$11,12,95,96,98,99,100$

35,46

$27,76,78,81$

$29,97,98$

24,54

$11,14,61,62,63$

$11,86,90$

11,60

$11,18,23,42,48,54,59,60$

11,41

$11,18,73,80$

28,81

$10,56,92$

$11,12,21,23,25,28,29,89,91,96,97,98,99$, 100

$8,12,13,29,40,46,49,55,61,63,75,77$

$12,23,25,34,42,44,46,47,48,50,51,62,63$

12,45

$12,15,24,33,34,65,66,67,68,72,75,76,82$

$8,12,18,41,42,48,59$

$12,13,21,28,31,53,54,55,56,57,59,62,63$

$13,39,44$

$13,65,95,96$

9,50

$13,18,22,23,53,54,69,71,72,80,85,87,93$

$12,13,16,30,40,41,50,55,59,61,63,75,86$,

$88,90,92$

$23,43,45$

9,45

13,37

$28,97,99$

$14,42,45$

$13,21,62,80,90,91,93$

$9,13,30,31,50,54,55,57,72,76,82$

14,38

$14,19,28,29,65,66,68,97,99,100$

$14,95,96,98$

34,77

14,70

$31,70,72$

$12,14,15,65,80$

26,97

27,79

14,38

21,51 
Csejtey, Bella, Jr.

Curtin, G.C.

Curtis, S.M.

Cushing, G.W.

Czamanske, G.K.

Dadisman, S.V.

Day, G.W.

Dean, R.M.

Dearborn, L.L.

Decker, J.E.

Delevaux, M.H.

Detra, D.E.

Detterman, R.L.

Dickinson, K.A.

Dillon, J.T.

Diment, W.H.

Dixon, K.L.

Dobrovolny, Ernest

Douglass, R.C.

Douglass, S.L.

Dover, J.H.

Doyle, P.F.

Dumoul in, J.A.

Dusel-Bacon, Cynthia

Dutro, J.T., Jr.

Duttweiler, K.A.

Easton, J ames

Eberlein, G.D.

Egbert, R.M.

Eittreim, Stephen

Ellersieck, I.F.

Elliott, R.L.

Emanuel, R.P.

Emme1, K.S.

Emett, W.W.

Ennis, R.A.

Erdman, J.A.

Evarts, R.C.

Evenson, E.B.

Feulner, A.J.

Ficklin, W.H.

Fierstein, J.E.

Filipek, L.H.

Fischer, J.M.

Fisher, M.A.

Flett, T.O.

Fogleman, K.A.

Folger, P.F.

Forbes, R.B.

Ford, A.B.

Forester, R.M.
$8,14,19,25,26,30,70,72,73,74,75,76,78$, $79,80,83$

$14,16,38,71$

$14,16,24,25,41,42,43,46,48,50$

$11,14,17,61,62,63$

$10,86,88,89,92$

23,97

14,38

26,70

14,89

$14,15,21,28,67,73,75,88,91,92,93$

$13,18,53,54,69,71,72$

$12,15,16,33,59,60,65,69,70$

$12,15,21,24,29,34,42,45,46,48,51,65,66$,

67,68

$15,69,71$

15,54

$32,39,40,97,100$

$20,28,77,79,81,87,93$

15,82

16,90

15,89

$15,24,59,61,63$

15,39

$15,24,29,53,54,55,56,70,72,74,76,80$

$7,15,17,60,61,62,63$

$9,11,15,16,17,26,28,29,41,43,45,46,48$,

$49,50,51,55,56,59,61,63,90$

$16,41,42$

31,53

$13,16,30,86,88,90,92$

$16,23,25,45,49,66,67,68,76,78$

$16,96,99,100$

$14,16,24,32,41,42,43,48,50$

$9,16,20,22,85,86,87,88,89,90,92,93$

$9,14,35,68,70,73$

$27,55,56$

11,60

25,48

$16,85,87,89$

$14,70,74,80$

$16,69,70,71$

16,44

$17,85,87$

$19,66,67,68$

$16,17,85,87$

11,96

$11,17,24,95,96,97,98,100$

$27,55,56$

$22,27,32,79$

$17,18,21,30,41,42,43,71$

$33,60,62,63$

$10,11,17,19,22,85,86,87,88,89,90,92,93$

$12,42,44,47$ 
Forn, C.L.

Foster, H.L.

Fox, J.E.

Frank, C. 0 .

Freethey, Geoffrey

Fuis, G.S.

Galloway, J.P.

Gamble, B.M.

Gardner, J.V.

Garrow, H.C.

Garwin, S.L.

Gehrels, G.E.

Gilbert, W.G.

Giovanetti, Dennis

Glude, William

Goerz, D.J., III

Goldfarb, R.J.

Gough, L.P.

Grantz, Arthur

Graves, Scot

Gray, J.E.

Gray, L.B.

Grome, C.S.

Grunder, Anita

Grybeck, Donald

Hamilton, T.D.

H ammars trom, J.M.

Hanson, S.L.

Harris, A.G.

Hartz, R.W.

Hassler, M.H.

Hazel, J.E.

Herman, B.M.

Herzon, P.L.

Hessin, T.D.

Hildreth, Wes

Hill, E.R.

Hillhouse, J.W.

Himmelberg, G.R.

Hoare, J.M.

Hoffman, J.D.

Holmes, M.L.

Hopkins, D.M.

Hopper, M.G.

Huber, D.F.

Hudson, Travis

Huffman, A.C.

Huggett, Quentin
$14,20,38,87$

$7,11,14,15,17,20,21,22,24,33,59,60,61$, 62,63

20,49

$17,35,45,46,50$

17,73

$17,18,73,80$

$12,18,33,37,44,47,48,62,63$

$18,35,53,65,67,68$

21,96

9,77

$10,86,89$

$18,30,86,88,89,93$

29,66

$18,24,43,50,75,78$

31,44

14,80

$17,18,28,41,42,69,70,71,85,87$

30,69

$16,18,25,30,32,34,49,72,76,82,83,95,96$,

$98,99,100$

$8,96,99$

$13,18,69,71,72$

$31,54,57$

$10,18,19,43,44,73,80,83,86,88,89,92$

$19,66,67,68$

$10,18,26,30,34,38,41,42,43,45,48,49,50$,

$85,86,87,89$

$18,19,43,46,47,48,49,50,60,62$

$35,91,93$

$32,39,40,97,100$

$8,9,21,26,28,29,46,49,61,63,75,76,77$,

$78,90,91,93$

20,49

27,79

12,48

$33,95,98,100$

$7,27,72,74,78,81$

$14,19,38,87$

$19,66,67,68$

26,78

$18,19,43,44,73,80,83$

$10,19,23,46,50,55,56,85,86,87,88,89,90$, 93

$14,15,19,21,65,66,67,68$

$14,20,27,38,71,87$

$17,95,96,100$

$11,12,19,20,43,44,47,48,49$

$32,39,40,97,100$

23,37

$20,28,29,46,49,53,55,56,63,70,76,77,78$,

$79,80,81,85,87,90,91,93,94$

$7,9,20,25,41,42,46,48,49$

21,96 
Huie, Car1

Hummel, C.L.

Hunt, S.J.

Hunter, R.E.

Huston, D.L.

J achens, R.C.

Jager, Larry

Jansons, Uldis

Jenne, E.A.

Johns on, B.R.

Johnson, K.A.

Johnson, K.M.

Johnson, Kirk

Johnston, D.A.

Jones, D.L.

Jones, G.M.

Jones, S.H.

Kachadoorian, Reuben

Kalechitz, Georgiana

Karl, H.A.

Karl, S.M.

Kaufman, D.S.

Keith, T.E.C.

Keller, Gerta

Kempema, E.W.

Kernodle, D.R.

King, H.D.

Kirk, A.R.

Kistler, R.W.

Klock, P.R.

Koch, R.D.

Kososki, B.A.

Koster, E.A.

Krumhardt, Andrea

Krystinik, L.F.

Kvenvolden, K.A.

Lachenbruch, A.H.

Lahr, J.C.

Laird, Jo

Lamb, Beth

Lancaster, G.A.

Lange, I.M.

Lankford, S.M.

Lanphere, M.A.

Lantz, R.J.

Larsen, B.R.

Lawver, L.A.

Leach, D.L.

LeCompte, J.R.

Lee-Wong, Florence

Leeman, W.P.
$10,13,41,50,86,92$

$20,32,53,55$

$10,11,20,28,29,86,90,92,93,97,99,100$

20,49

14,71

$10,85,86,88,90$

$19,66,67,68$

16,41

$26,53,54,95,96,97$

$10,13,14,18,20,21,24,40,53,55,85,86,87$,

$89,92,93$

11,96

34,82

$20,96,99$

$20,21,68$

$13,14,17,19,21,28,29,30,40,46,49,54,61$,

$62,66,75,80,81,82,90,91,93$

$21,59,60$

$21,39,44$

$21,27,51,74,77,78,82$

$30,72,82$

$11,21,96,99$

$10,15,20,21,26,43,53,55,65,68,75,76,78$,

$89,91,93$

$21,29,40,55,56$

$17,21,22,24,33,59,60,61,62,68$

$29,72,76$

$29,97,100$

$13,25,39,44,74$

$14,16,22,38,54,69,70,71$

$20,25,41,42,49$

$10,86,88,89,92$

$30,72,82$

$9,16,22,85,86,87,88,89,90,92,93$

25,45

$18,47,48$

22,61

$25,45,49$

$14,42,45$

$22,39,44$

$22,32,79,91,92$

$11,14,22,61,62,63$

$21,96,99$

$19,43,47,49$

$27,69,75,81$

$22,66,67$

$24,28,30,54,60,72,75$

12,45

$26,53,54,95,96,97$

22,39

$18,85,87$

$7,18,22,32,38,40,42,48,87,91$

$31,95,97$

29,83 
Lehuray, A.P.

Leonard, K.R.

Levy, W.P.

Light, T.D.

Lins, H.F., Jr.

Lisowski, Michael

Loeffler, R.

Loney, R.A.

Long, C.L.

Lul1, J.S.

Lyle, W.M.

Mackevett, E.M., Jr.

Madison, R.J.

Madrid, R.J.

Magoon, L.B.

Maley, R.P.

Mamet, B.L.

Mammay, S.H.

Mankinen, E.A.

Maple, E.J.

Marincovich, Louie, Jr.

Marlow, M.S.

Marsh, S.P.

Marshall, B.V.

Mathews, Alan

Matooka, J.M.

Mayfield, C.F.

Mayo, L.R.

Mays, R.E.

McCammon, R.B.

McClellan, P.H.

McCoy, G.A.

McDanal, S.K.

McDougall, Kristin

McLean, Hugh

Meckel, J.P.

Meier, M.F.

Menzie, W.D.

Meyer, C.E.

Miller, J.W.

Miller, M.L.

Miller, R.J.

Miller, T.P.

Miller, W.A.

Mitchell, Heidi-Lynn

Mitchel1, P.A.

Miyaoka, Ronny

Molenaar, C.M.

Moll, E.J.

Molnia, B.F.

Mooney, W.D.

Moore, G.W.

Moore, H.J.
$13,22,23,53,54,69,80,85,87,93$

23,37

$12,96,100$

$8,18,23,59,60,71,85,87,92$

$23,74,75,77,96,98,99$

$23,67,79$

$13,39,44$

$10,23,46,50,55,56,85,86,88,89,90,92$

23,43

$23,29,71,73,76,78,81$

$27,55,56,65,74$

$8,30,34,69,70,72,76,77,82$

23,39

12,45

$14,16,22,23,42,43,45,66,67,68$

27,79

$8,16,45,48,90$

23,55

$23,87,88,91$

23,97

$11,12,23,42,44,46,47,48,90$

$14,23,95,96,97,98$

$14,23,38,60$

$22,39,44$

$30,69,71,72$

$16,85,87,89$

$13,14,16,23,24,25,32,41,42,43,44,45,48$, 49,50

$24,39,40,74,77$

$20,53,55$

$23,59,60$

$24,75,78,97,98$

$24,39,44,89$

27,38

$11,12,48,96$

$24,66,67$

$24,44,51$

$24,29,39,40,74$

$21,24,59,60,62$

29,40

$7,15,24,35,66,67,68$

$7,15,24,26,29,50,54,70,72,74,76,80$

$34,72,75,76,82$

$20,24,31,35,53,54,55,60,68,83$

30,77

$20,96,99$

$30,70,72$

$15,24,27,59,61,63,70,75,76,78,81$

$20,24,25,41,42,45,49$

$12,15,25,28,31,53,54,55,56,57$

$11,12,25,29,89,91,96,97,98,99$

$18,73,80$

$24,97,98$

$21,74,82$ 
Moore, T.E.

Morehouse, J.A.

Morgan, A.V.

Morgan, Anne

Morin, R.L.

Morrel1, R.P.

Morrissey, L.A.

Morton, J.L.

Moses, T.H., Jr.

Mosier, D.L.

Mosier, E.L.

Mukasa, S.B.

Mull, C.G.

Mullen, M.W.

Munroe, R.J.

Murchey, B.I.

Murphy, J.M.

Naeser, C.W.

Nauman, J.W.

Neher, F.R.

Nelson, C.A.

Nelson, C.H.

Nelson, G.L.

$\mathrm{Nel}$ son, Hans

Nel son, R.E.

Nelson, S.W.

Nelson, W.H.

Newberry, R.J.

Nilsen, T.H.

Nishi, J.M.

Nissenbaum, Arie

Nokleberg, W.J.

Nutt, C.J.

O'Leary, R.M.

O'Neil, J.R.

Ormiston, A.R.

Osbakken, W.E.

Oscarson, R.L.

Ovenshine, A.T.

Page, N.J.

Page, R.A.

Palmer, A.R.

Palmer, I.F.

Panuska, B.C.

Parks, Bruce

Parrish, J.T.

Parson, L.M.

Patton, W.W., Jr.

Pearl, J.E.

Perkins, D.M.

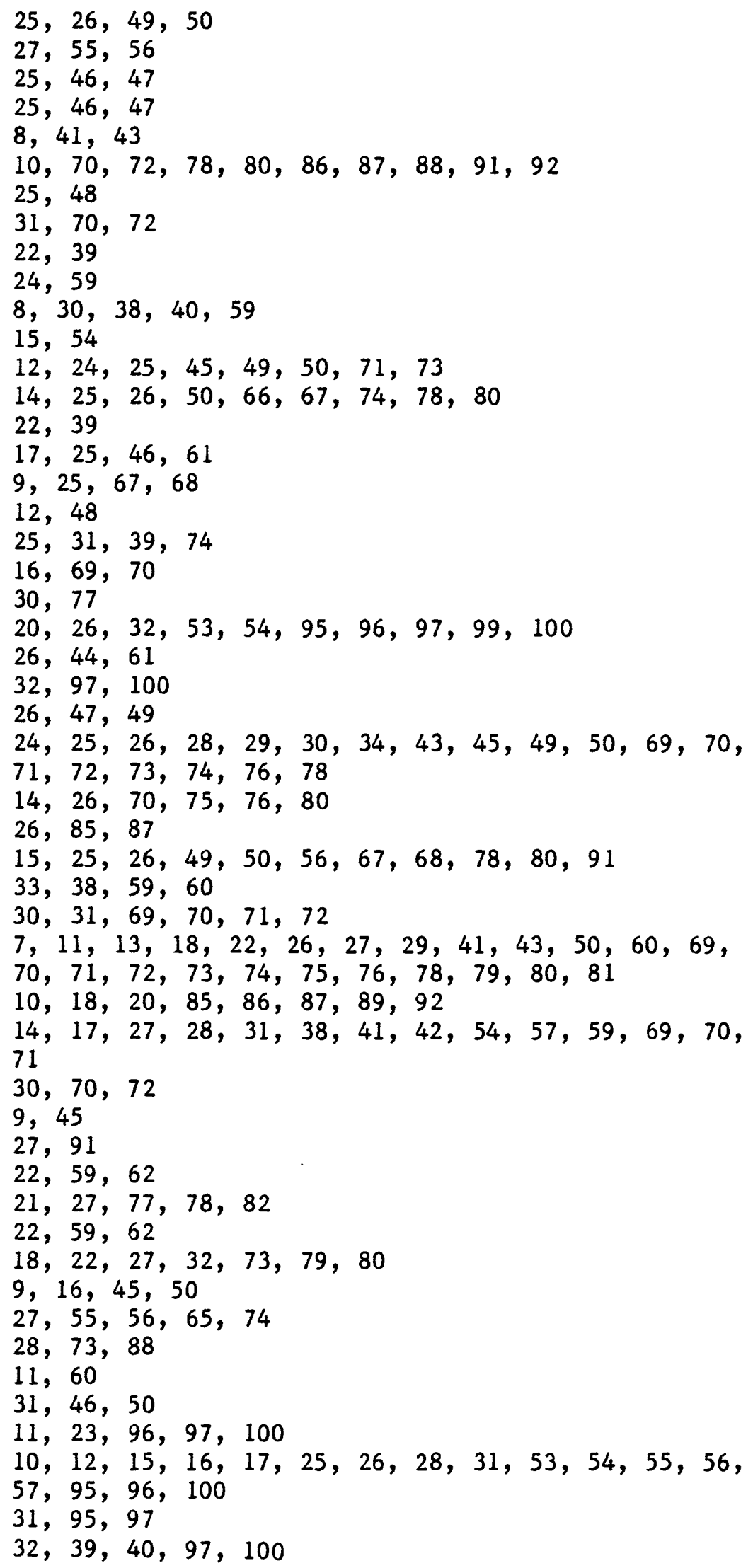




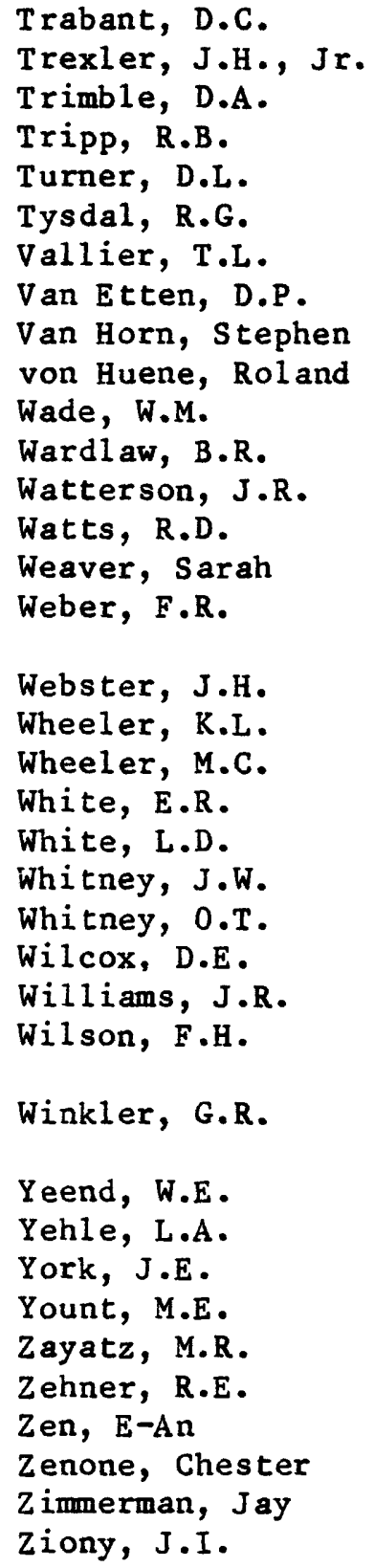

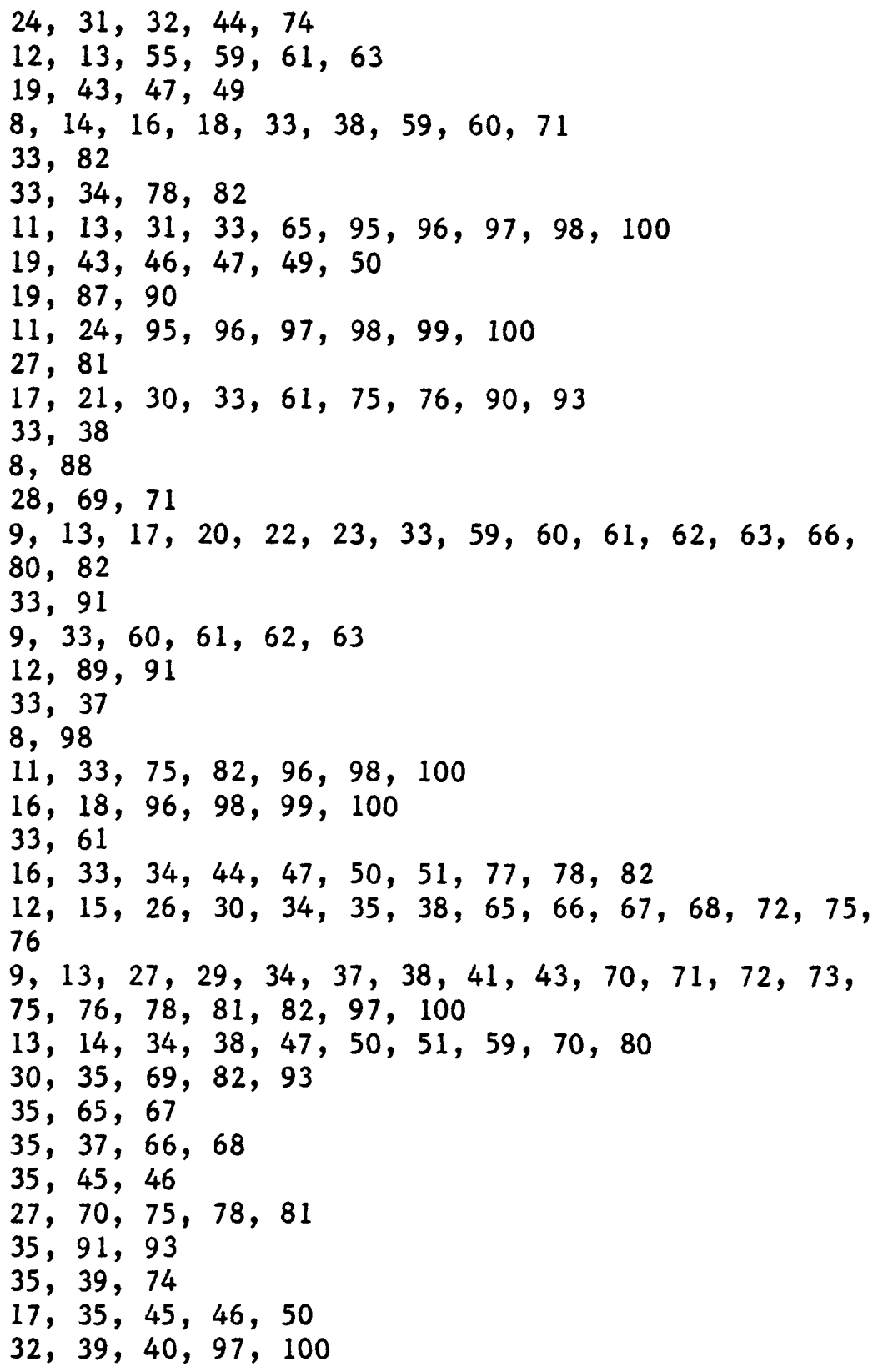

